\title{
Geological and Geochemical Controls on Non-Tuberculous Mycobacterium Transmission: Examples from Hawaii
}

\author{
Schuyler Thomas Robinson
}

Brigham Young University

Follow this and additional works at: https://scholarsarchive.byu.edu/etd

Part of the Microbiology Commons, and the Physical Sciences and Mathematics Commons

\section{BYU ScholarsArchive Citation}

Robinson, Schuyler Thomas, "Geological and Geochemical Controls on Non-Tuberculous Mycobacterium Transmission: Examples from Hawaii" (2019). Theses and Dissertations. 8558.

https://scholarsarchive.byu.edu/etd/8558

This Thesis is brought to you for free and open access by BYU ScholarsArchive. It has been accepted for inclusion in Theses and Dissertations by an authorized administrator of BYU ScholarsArchive. For more information, please contact ellen_amatangelo@byu.edu. 
Geological and Geochemical Controls on Non-Tuberculous Mycobacterium

Transmission: Examples from Hawaii

Schuyler Thomas Robinson

A thesis submitted to the faculty of

Brigham Young University

in partial fulfillment of the requirements for the degree of

Master of Science

Stephen Tracy Nelson, Chair

Zachary Thomas Aanderud

Barry R. Bickmore

Norman L. Jones

Department of Geological Sciences

Brigham Young University

Copyright (C) 2019 Schuyler Thomas Robinson

All Rights Reserved 


\author{
ABSTRACT \\ Geological and Geochemical Controls on Non-Tuberculous Mycobacterium \\ Transmission: Examples from Hawaii \\ Schuyler Thomas Robinson \\ Department of Geological Sciences, BYU \\ Master of Science
}

The opportunistic environmental microbes, non-tuberculous Mycobacterium (NTM), pose an increasing risk of disease and death in both immunodeficient and immunocompetent individuals in the USA and across the world. NTM lung disease is particularly prevalent in Hawaii, although the modes of NTM acquisition and transport in Hawaii are not fully understood. This study evaluated 149 soil and 50 water samples across the Hawaiian Islands to determine geochemical factors controlling NTM. Non-metric multidimensional scaling (NMDS) and principal component analyses (PCA) of modern soils show variables such as Total Organic Carbon (TOC), $\mathrm{pH}, \mathrm{P}$, mafic silicate minerals, and $\mathrm{Pb}$ seem to control NTM presence and transition metals and oxides such as $\mathrm{TiO}_{2}, \mathrm{Zr}$, and $\mathrm{Nb}$ seem to control the absence perhaps due to toxicity. Logistic regression modeling coupled with Kolmogorov-Smirnov testing supported that TOC and P could be used to explain the probability of NTM presence in modern soils.

Kolmogorov-Smirnov, non-metric multidimensional scaling, and principal components analysis results suggest poor predictability of NTM presence in soils when evaluating mineralogy alone. The same statistical methods indicated that transition metals appeared to control NTM presence in stream water and major cations and anions seemed to control NTM absence. However, additional bacterial stream data is needed to strengthen this finding.

Additionally, an Oahu source water assessment and protection groundwater model was refined by including stream discharge data, including losses to the aquifer. NTM inhabits many environmental niches, although little is understood regarding the transport of NTM from the environment to indoor plumbing. However, transport from surface water to water-supply aquifers is likely important. This study analyzes groundwater flow from stream losses as a mechanism of NTM transport to water supplies. An updated MODFLOW groundwater model was developed for the north-east Oahu, Waimea River drainage. Results show hundreds of meters of lateral and tens of meters of vertical transport of NTM in 1-3 months. Additionally, geochemical modeling with Geochemist's Workbench showed Fe oxy/hydroxides oversaturated in $100 \%$ of streams. Fe oxy/hydroxide affixed to NTM would potentially satisfy NTM's preference for attachment and allow for colloidal transport through the aquifer.

Keywords: Mycobacteria, soil chemistry, logistic regression, particle tracking, Oahu, Kilauea, NTM, HVO, groundwater model, disease, PCA, NMDS 


\section{ACKNOWLEDGEMENTS}

This combined effort of geology and microbiology could not have been possible without the coordinating efforts of researchers at National Jewish Health, particularly Dr. Jennifer Honda. Funding for this project was generously provided by the National Science Foundation grant 1743587. I give many thanks to my committee (Drs. Steve Nelson, Barry Bickmore, Zach Aanderud, and Norm Jones), who made large contributions to the statistical methods, sampling strategies, groundwater model design, and critiques. Dr. Randy Larsen deserves credit for

helping to create scientifically sound, logistic models. Josephine Hoh and Richard Pezzulo were a great help in granting access and providing escorted sampling trips in Waimea Valley. Kevin Rey and Kaleb Markert assisted through field and lab support. Dave Tingey must be acknowledged for his intellectual support in preparing samples for analysis and instruction. My best friend and wife, Kaylee, has been a great support and encouragement through both the hard and comfortable aspects of this thesis, for which, I am very grateful. 


\section{TABLE OF CONTENTS}

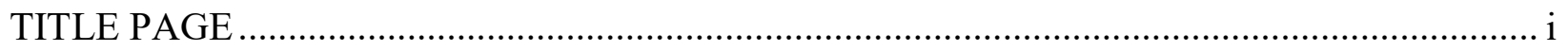

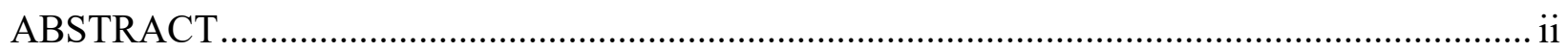

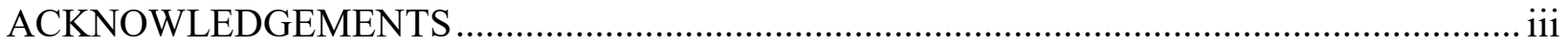

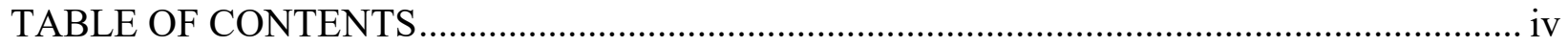

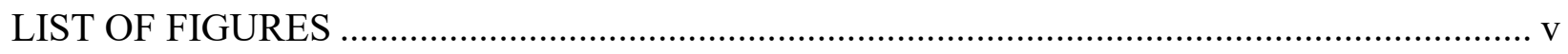

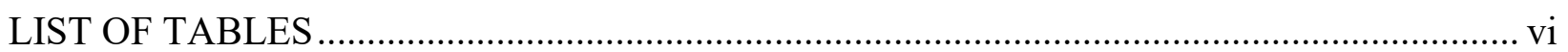

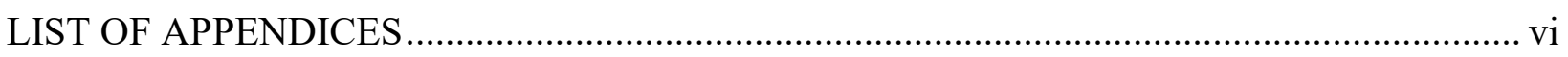

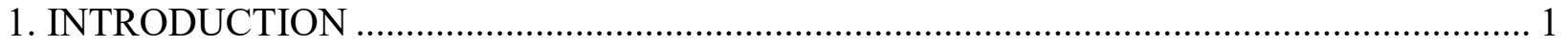

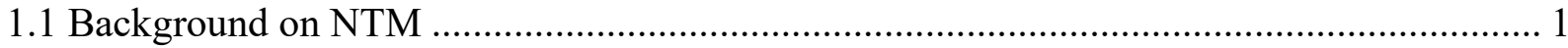

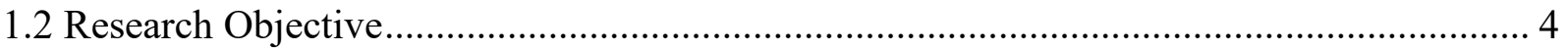

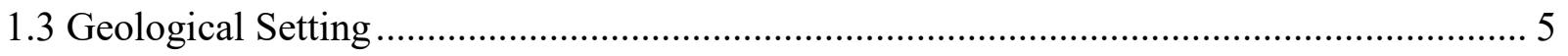

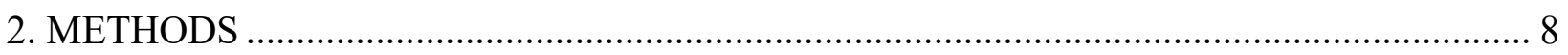

2.1 Sampling strategy and Selection of Localities ................................................................. 8

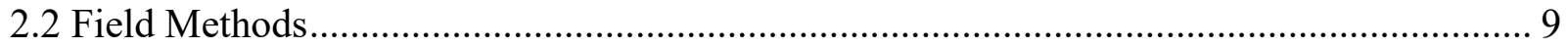

2.3 Laboratory Methods ………………………………............................................... 10

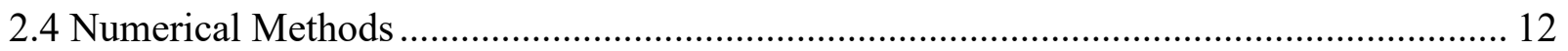

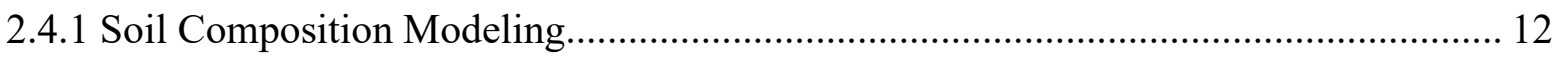

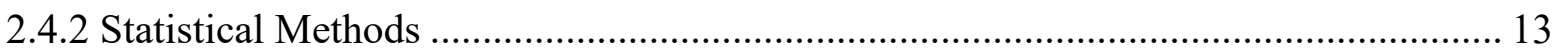

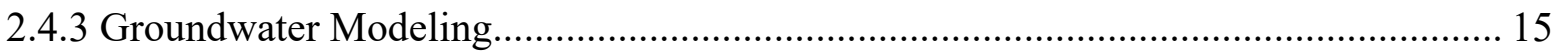

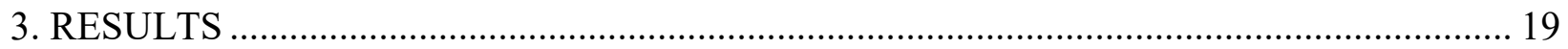

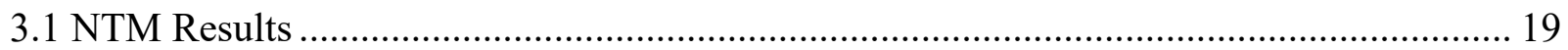

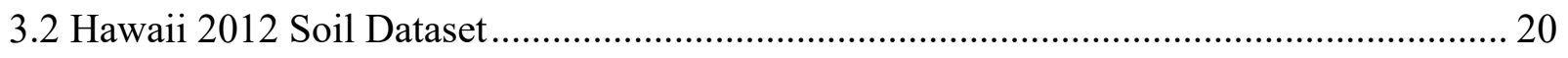

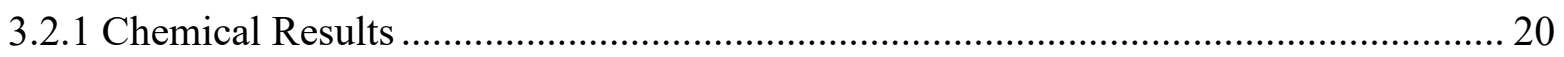

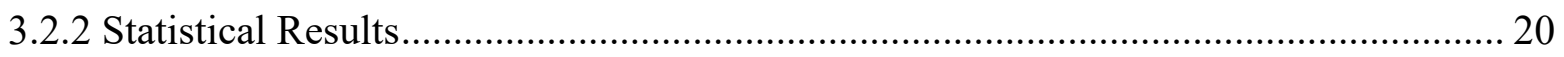

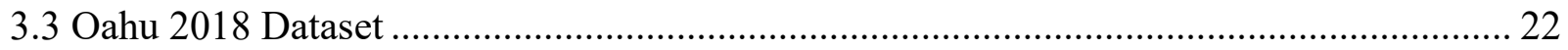

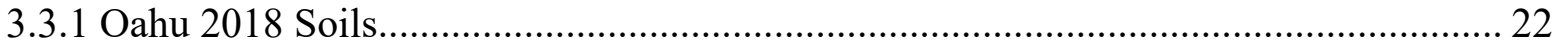

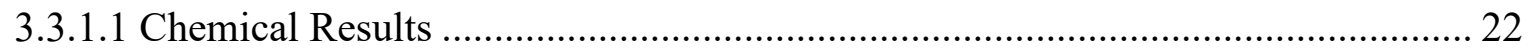

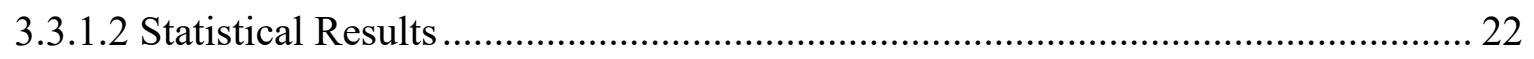

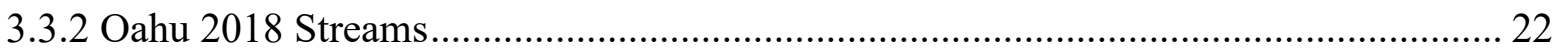

3.3.2.1 Chemical Results ..................................................................................... 22

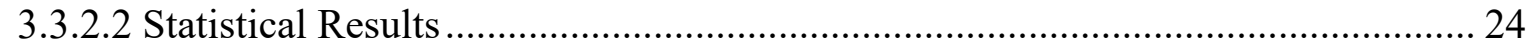




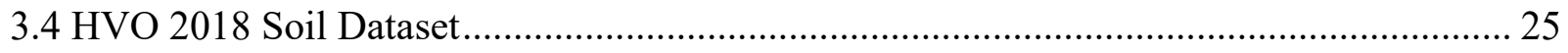

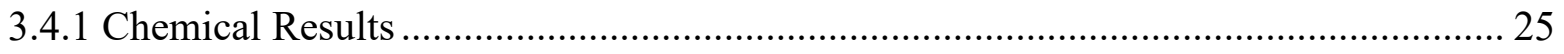

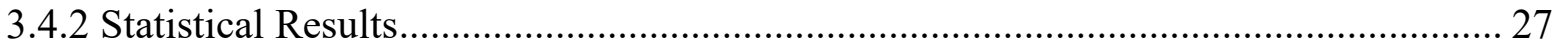

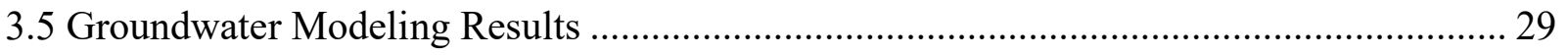

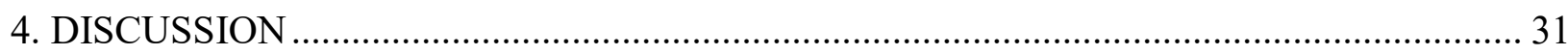

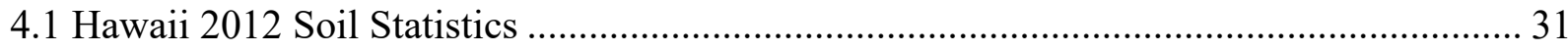

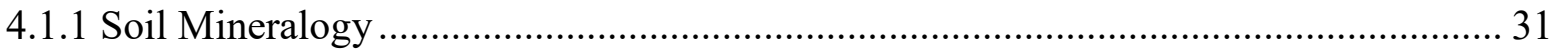

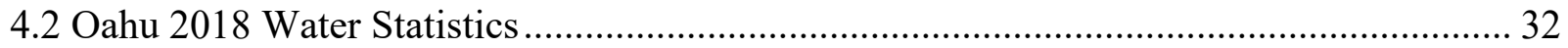

4.2.1 Controlling Variables Relationship with NTM ...................................................... 32

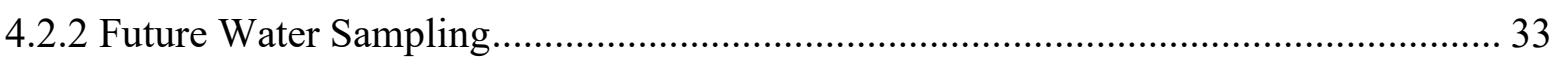

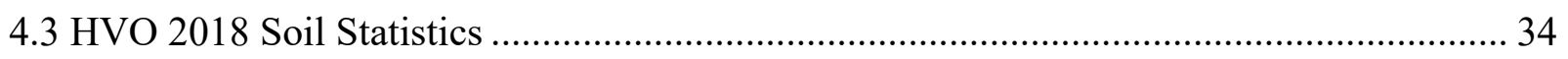

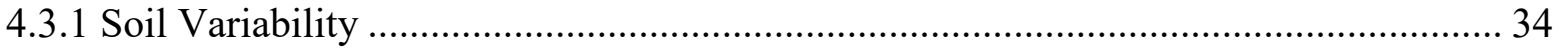

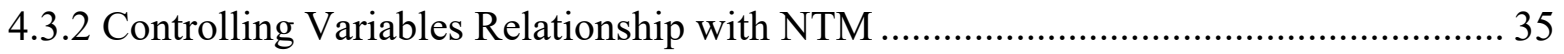

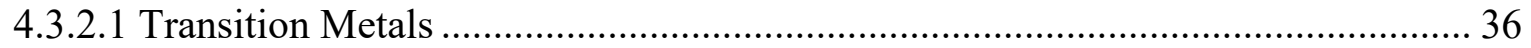

4.3.2.2 TOC and Soil Acidity …………………………........................................ 37

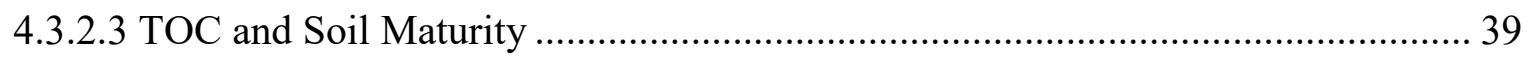

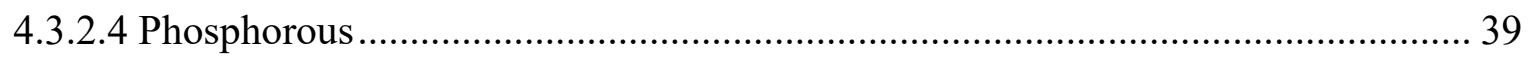

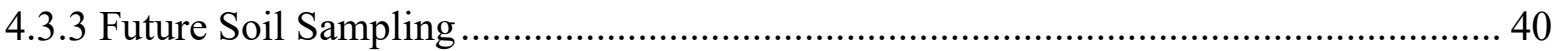

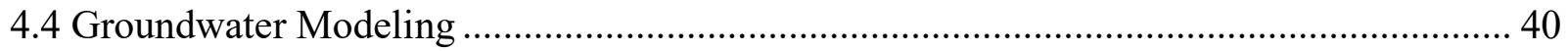

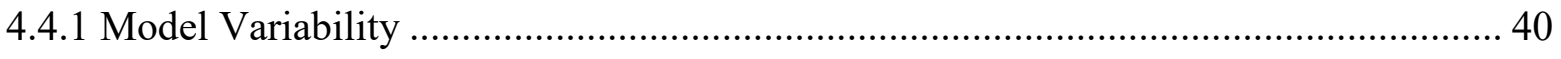

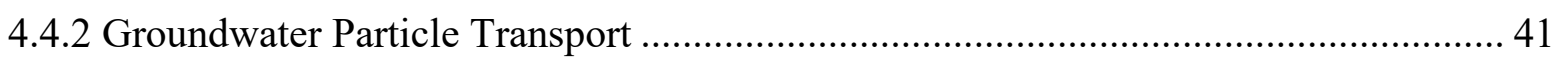

4.4.3 Additional NTM Transport Pathways ...................................................................... 44

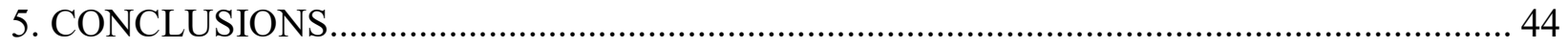

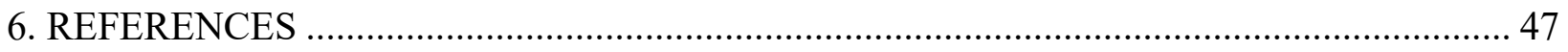

\section{LIST OF FIGURES}

Figure 1. Sampling locations of 2012, 2018 stream, and 2018 HVO datasets .............................. 54

Figure 2. Groundwater modeling location and boundaries in north-east Oahu ........................... 57

Figure 3. PCA plots of HVO 2018 soil chemistry, Oahu 2018 soil chemistry, and 2012 soil

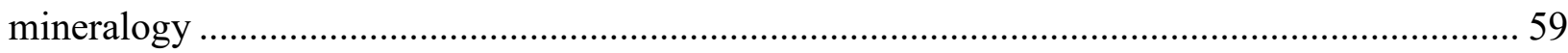


Figure 4. Piper diagram of Oahu 2018 August surface and groundwater samples.................... 60

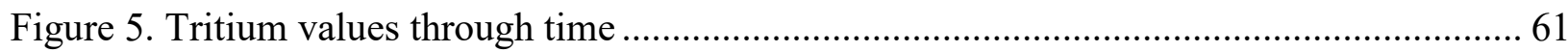

Figure 6. NMDS plots of Oahu 2018 stream and HVO 2018 soil chemistry .......................... 62

Figure 7. $\tau$ diagrams of elemental leaching and enrichment of HVO soils ..............................63 63

Figure 8. SiO2 plots of HVO soil immobile and mobile oxides............................................. 64

Figure 9. Histograms and Kolmogorov-Smirnov tests statistics for HVO soils....................... 65

Figure 10. Hydraulic head calibration results from 6 observation wells used in the $\mathrm{Kh} / \mathrm{Kv}=20$

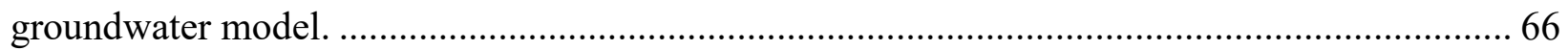

Figure 11. Particle tracking analysis and capture zones of wells 3803-01 and 3803-03 ............ 66

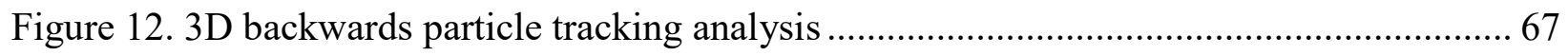

\section{LIST OF TABLES}

Table 1. Probable habitats of non-tuberculous Mycobacterium ............................................... 68

Table 2. Kolmogorov-Smirnov tests for HVO 2018 soils, Oahu 2018 streams, and Hawaii 2012

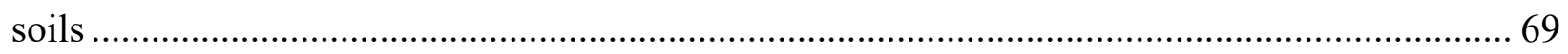

Table 3. Logistic regression model selection and results for Hawaii 2012 soil chemistry........... 70

Table 4. Logistic regression model selection results for HVO soil chemistry. ......................... 71

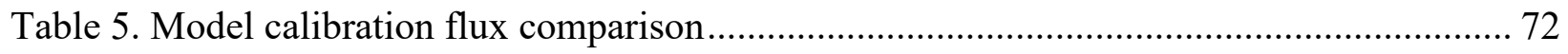

\section{LIST OF APPENDICES}

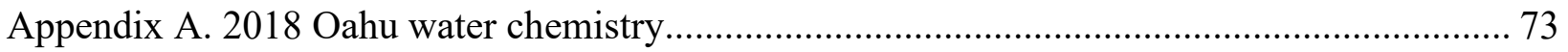

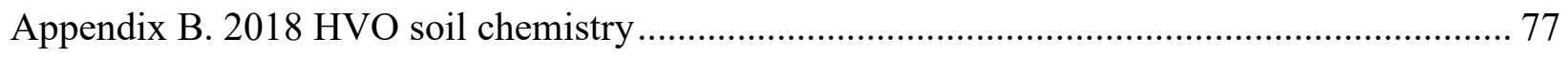

Appendix C. Stream to Aquifer Modeling from Nelson et al. (In Press) ................................. 81 


\section{INTRODUCTION}

The genus Mycobacterium is the cause of increasing deaths in the USA and across the world due to pulmonary complications (Reyn et al., 1993). Hawaii, in particular, is the USA leader in non-tuberculous Mycobacterium (NTM) infections with an age-adjusted average mortality rate from NTM that is 2-4 times greater than the United States mainland rate (Mirsaeidi et al., 2014; Honda et al., 2016). The NTM-related mortality rate in Hawaii is 9 times higher than the lowest NTM related mortality rate state in the continental US (e.g. Michigan) (Mirsaeidi et al., 2014). Indoor plumbing has often been demonstrated to host NTM (Falkinham III, 2011). Associated micro-droplets are one major infection pathway for NTM to humans (Falkinham III, 2009).

NTM are common in the environment (Tuffley and Holbeche, 1980; Falkinham III et al., 1980; Reyn et al., 1993; Honda et al., 2016). Recent studies have summarized favorable NTM habitats (Table 1). However, few have explored in-depth geochemical correlations due to the complex and diverse habitats of NTM (Cook, 2010). This study evaluates potential hydrogeological and geochemical correlations to NTM and plausible pathways from NTM in the environment to humans.

\subsection{Background on NTM}

The genus Mycobacterium has >175 identified species (Honda et al., 2016). Eleven of those species are the cause of tuberculosis in animals and humans and three are sources of leprosy. The other approximately 160+ Mycobacterium species are labeled as non-tuberculous Mycobacterium (NTM). The most common species of NTM infecting US citizens are M. avium and M. intracellulare, otherwise known as Mycobacterium avium complex (MAC) (Falkinham III, 2011; Honda et al., 2016). 
As groups, NTM are both slow and fast growing. Generally, Mycobacteria grow slower than other human pathogenic bacteria (Ryan et al., 2004), yet have the same high metabolism as other microbes, which allows them to adapt rapidly, enhancing survival in disinfectant environments, particularly chlorine (Taylor et al., 2000; Falkinham III, 2009, 2013), which is 580 to 2,300 times greater than that of E. coli (Lipner et al., 2017). Relative to preferred habitat and transport, NTM generally have a net negative cell wall or surface charge (Lytle et al., 2004). They are hydrophobic because of an outer membrane's mycolic acids, which cause an inclination for surface attachment (Falkinham III, 2009), and are oligotrophic and able to grow in low nutrient environments with as low as $50 \mu \mathrm{g} / 1$ of assimilable or reduced organic carbon (Falkinham III, 2002; Norton et al., 2004; Elharar et al., 2014).

The incidence of mainland United States NTM infections is about 100 cases per 100,000 people (Adjemian et al., 2012), and is increasing in the United States and Canada (Falkinham III, 2011; Mirsaeidi et al., 2015). Manifestation of the disease in relatively immunocompetent hosts is pulmonary disease. Immunoincompetent hosts (e.g. those with AIDS, COPD, etc.) develop a disseminated or widespread disease throughout the body (Falkinham III, 2011).

Risk factors include 1) immune incompetence because of HIV (human immunodeficiency virus), AIDS (acquired immune deficiency syndrome), cancer, chemotherapy, and transplant immunosuppression, 2) preexisting lung disease including chronic obstructive pulmonary disease (COPD), pneumoconiosis, silicosis, and prior tuberculosis), 3) altered chest architecture, 4) alcoholism, and, 5) smoking (Taylor et al., 2000; Falkinham III, 2009, 2011). The incidence of NTM lung disease is elevated among elderly, slender individuals (Falkinham III, 2009; Lipner et al., 2017), including women without any pre-existing conditions (Falkinham III, 2011; Mirsaeidi et al., 2014). In a recent spatial study of NTM, counties across the USA were high risk if they 
were larger in size, had high population density, high mean minimum and maximum temperatures, and had higher education and income levels (Adjemian et al., 2012). However, education may be a proxy for better health care and older age may be a predisposing cause for illness (Adjemian et al., 2012; Lipner et al., 2017). Another study showed that higher elevation correlated to increased NTM up to $4000 \mathrm{~m}$, with water temperatures between $17-23^{\circ} \mathrm{C}$ (i.e. similar to Hawaiian waters), and that environmental correlations and NTM species diversity may vary locally (King et al., 2017). Although patients can be cured, they are often re-infected with the same or another NTM species (Lipner et al., 2017). The source of NTM can be traced back to the environment, particularly soil and surface water (Brooks et al., 1984). Given that NTM prefer attachment, they are seldom isolated from groundwater (Falkinham III, 2011; Adjemian et al., 2012; Honda et al., 2016). If in water, NTM will preferentially attach to a particle than remain in suspension (Falkinham III, 2002). In this context, a better understanding of the natural environments inhabited by NTM, as well as possible transmission routes to humans, are highly desired.

In addition to the habitats summarized in Table 1, the following environmental correlations to NTM have been made and are expected to influence NTM in Hawaii. Acidic soils increase the risk of NTM habitation (Brooks et al., 1984; Falkinham III, 2002). As mentioned above, Norton (2004) showed that NTM can thrive in very low nutrient environments, which suggest that low TOC habitats could be favorable. However, Brooks et al. (1984) noted a weak correlation between TOC and NTM. Mn and P both increase the relative risk of habitation according to Lipner et al. (2017). Overall, $\mathrm{Mn}, \mathrm{Fe}, \mathrm{Co}, \mathrm{Zn}, \mathrm{Sr}, \mathrm{Y}, \mathrm{Zr}, \mathrm{La}, \mathrm{Ce}$, and $\mathrm{U}$ are elements that have been shown to be taken up by certain types of bacteria (Mueller, 2015). Lipner et al. 
(2017) also proposed that silt size particles increase NTM survival, potentially causing different levels of risk between individual watersheds.

Three major routes of transmission for human infection have been identified: aerosols from showerheads and tap waters, ingestion from waters and soils inhabited by NTM, and inhalation of dust from soil, particularly potting soil (Falkinham III, 2013). Concerning the aerosols from indoor plumbing, previous studies have suggested water distribution centers might have been the NTM source (Torvinen et al., 2004). However, given direct well to home connections, NTM may have originated from groundwater. Groundwater may have been bacterially contaminated by water droplets that traveled through the vadose zone, or through stream loss.

NTM household dust and associated NTM inhabited soils suggest infection via inhalation (Dawson, 1971; Tuffley and Holbeche, 1980). The DNA fingerprint of NTM found inhabiting both infected patients and their showerheads suggest aerosols as a source of infection (Falkinham III, 2011). Feazel et al. (2009) have shown that showerheads contain biofilms rich in NTM and other microbes. Aerosolization of water from the showerhead may produce airborne water droplets contaminated with NTM, which humans inhale and potentially become infected (Feazel et al., 2009). Different species of NTM may have different sources and routes of transmission, however (Lipner et al., 2017).

\subsection{Research Objective}

This research partially contributes to the overall, multi-institutional goal to locate the environmental sources (e.g. soils, surface water, groundwater, etc.) of non-tuberculous Mycobacterium (NTM) on the Hawaiian Islands, correlate their presence with water and soil geochemical characteristics, and infer the mode(s) of human NTM infection. Previous studies 
have focused on biological characteristics of NTM with general soil and water data. This study is part of a collaboration between National Jewish Health and Brigham Young University to combine detailed biological and geological analyses to further establish NTM infection pathways and habitats. This research focused on the geological and inorganic features of the Islands through the study of streams, wells, and soils. Water and soil chemistry and mineralogy are statistically correlated with the presence or absence of NTM in order to infer how and/or why water and soil geochemical parameters control NTM growth and survival. Additionally, there are multiple routes of infection from the environment to homes and this study attempts to address groundwater infection pathways of NTM through the use of a numerical groundwater flow model.

\subsection{Geological Setting}

The Hawaiian Islands provide an optimal natural laboratory for this study because of abundant NTM, geographical and thus geochemical isolation, and well-defined and known geological characteristics. The area of study encompasses the major and inhabited Hawaiian Islands with a focus around the Ko'olau Range on eastern Oahu and the Hawaiian Volcanic Observatory (HVO) on the Island of Hawaii prior to the 2018 Kilauea eruptions. The Hawaiian islands range from approximately 5 Ma to the present (McDougall, 1979; Sherrod et al., 2007). The Ko'olau Range of Oahu was formed subaerially, 2.6 - 1.8 ma with rejuvenated, alkalic, Honolulu Series ages less than 0.6 ma (Doell and Dalrymple, 1973; Lanphere and Dalrymple, 1980; Sherrod et al., 2007). The Kilauea volcano began erupting at approximately $0.35 \mathrm{Ma}$ with periods of inactivity throughout (Quane et al., 2000). Recent eruptive activity lasted from 1983 to 2018 . 
The Hawaiian islands are dominantly comprised of tholeiitic basalt with minor amounts of alkalic basalt (Sherrod et al., 2007). The tholeiitic basalt was erupted during the shield-building phase of the volcano and alkalic basalt erupted during the pre-shield, post-shield, and rejuvenation stages (Decker et al., 1987). Hawaiian basalt weathering is well understood with parent minerals of pyroxene, olivine, and feldspar in fresh basalts on younger islands to secondary kaolinite/halloysite and gibbsite, as well as Fe oxide and hydroxide minerals, in laterite zones (i.e. weathered basalt profiles) across all Hawaiian Islands (Parfitt et al., 1988). This weathering progression from basalt to clays and Fe oxides provides a controlled and well understood environment for this study. Laterite thickness and degradation from basalt to clay and Fe oxides and hydroxides is variable across the Islands as a function of rainfall, soil moisture, and age of the island with thicker laterite zones developing in older, wetter areas and thinner zones in younger, drier areas. (Chadwick et al., 2003; Chorover et al., 2004; Nelson et al., 2013; Yaede et al., 2015; Sowards et al., 2018). Laterite development occurs through chemical weathering, which involves leaching of mobile elements such as $\mathrm{Si}, \mathrm{Ca}, \mathrm{Mg}, \mathrm{Na}$, and $\mathrm{K}$ into streams and groundwater (Nelson et al., 2013).

Geologically, the focus of this study is the soil or upper laterite zones and its interaction with NTM as well as an investigation of NTM transport through the basal aquifer. Chorover et al. (2004) concluded that approximately $400 \mathrm{ka}$ of chemical weathering in fresh basaltic minerals (e.g. pyroxene, glass, olivine, and feldspar) produces allophane, microcrystalline gibbsite, and ferrihydrite. 1,400 ka to 4,100 ka of weathering produces crystalline secondary minerals consisting of kaolinite, gibbsite, and goethite (Chorover et al., 2004). However, Sowards et al. (2018) did not find any evidence for allophane or ferrihydrite in the 300 ka substrate of Kohala suggesting that the secondary minerals chemically weather from the primary minerals by $300 \mathrm{ka}$. 
The different conclusions from Chorover et al. (2004) and Sowards et al. (2018) might be explained by less precipitation in the Kohala Peninsula than the model proposed by Chorover et al. (2004).

Oahu hydrology and groundwater modeling have been well-described in the literature (Mink and Lau, 1990; Lau and Mink, 1995, 2006; Hunt Jr., 1996; Shade and Nichols, 1996; Oki, 1998; Whittier et al., 2010; Gingerich and Oki, 2011). Hydraulically, Oahu can be divided into 3 main components: laterally-spreading basalt flows, dikes, and sedimentary deposits (Stearns and Vaksvik, 1935; El-Kadi and Moncur, 2005). Preferential flow occurs along intercalated aa and pahoehoe lava flow boundaries in the basalt aquifers (El-Kadi and Moncur, 2005). Due to the variability within a typical aa or pahoehoe basalt flow (e.g. aa clinker beds, aa fractured core stones, pahoehoe fractured flows, density and connectivity of vesicles, etc.), the hydraulic conductivity can vary widely. Aa flow stratigraphy typically comprises a clinker bed with high lateral permeability above and below a massive, basalt core stone with little to no lateral permeability and some fracture-induced, vertical permeability (i.e. several orders of magnitude lower than clinker beds) (Hunt Jr., 1996). Pahoehoe flows are thin and fluid-like, extending laterally. High lateral permeability in pahoehoe flows exist in voids between flows and drained lava tubes. Vertical permeability exists in cooling joints and fractures. Dike intrusions, particularly along the axial fissure zones (e.g. Ko'olau Range), and post-shield or rejuvenation stage ash and cinder can also alter the hydraulic conductivity by compartmentalization, considering fine-grained ash acts as an aquitard (Takasaki and Mink, 1985). Sedimentary deposits, particularly concentrated on the perimeter of the Islands and known as caprock, typically have lower hydraulic conductivity values than basalt (Hunt Jr., 1996). 
As mentioned previously, there are multiple routes for NTM infection. A poorly studied pathway involves the transport of NTM from the soil into the groundwater through aquifer recharge. Possible methods of transport from surface to aquifer are recharge through the vadose zone to the aquifer and stream losses into the aquifer.

Vadose zone modeling will not be addressed in this study. However, to better understand NTM travel times from streams to wells, a site was chosen to numerically model groundwater flow paths. The location for this portion of the study is Waimea Valley in north east Oahu. This area was selected because of simplified geology (e.g. dike free, laterally spreading basalt flows), 2 pumping wells on site, and a stream up-gradient from the wells (Mink and Lau, 1990). Given the stream is losing water to the aquifer (discussed below), the goal was to understand flow paths from the stream and determine any well intersections.

\section{METHODS}

\subsection{Sampling strategy and Selection of Localities}

As mentioned above, 16 stream water and associated stream bank, surface soils were sampled twice during the wet season (e.g. January and February 2018) and once during the dry season (e.g. August 2018) on Oahu (Fig. 1a) (Appendix A). January, February, and August samples have prefixes of 18-STR, 18-KAR, and 18-KRM, respectively. To better constrain NTM populations and examine differences with streams, two agricultural wells were sampled in Laie, HI. Due to sampling complications, bacterial data for the January sample set had a delayed analysis. Seven stream biofilms have been analyzed and are considered in this report. 51 soil samples were collected across the Hawaiian Islands (e.g. Kauai, Oahu, Maui, Molokai, and Hawaii) in 2012 as a preliminary study and results are shown in this study (Fig. 1c). 43 surface 
soil samples were collected near the Hawaiian Volcanic Observatory (HVO) during mid-January 2018 (Fig. 1d). Kilauea eruptions in May 2018 prevented a summer sampling.

\subsection{Field Methods}

Stream and well water were filtered in the field through a $0.45 \mu \mathrm{m}$ Nalgene filter with a cellulose nitrate membrane and stored in acid-washed high-density polyethylene bottles for cation and anion splits. The cation splits received 5 drops of $7 \mathrm{~N}$ trace-metal grade nitric acid for preservation. Cation and anion splits were refrigerated until analyses were performed. Stream and well sample waters were collected unfiltered and placed into a translucent glass bottle with a foil lined cap for total organic carbon (TOC) analysis and into an amber glass bottle with a poly seal cap for $\delta^{18} \mathrm{O}$ and $\delta \mathrm{D}$ analysis. The translucent glass bottles were ashed prior to sampling at $400^{\circ} \mathrm{C}$ for 4 hours. August TOC stream samples received 1-2 drops of $6 \mathrm{~N}$ hydrochloric acid to stabilize potential precipitants.

January, February, and August stream and well waters were collected unfiltered into acid washed $500 \mathrm{ml}$ and $250 \mathrm{ml} \mathrm{LDPE}$ bottles for $\mathrm{HCO}_{3}{ }^{-}$analysis. The bottles, prior to sample collection, were filled half full of $10 \%$ hydrochloric acid, heated to $60^{\circ} \mathrm{C}$ for 24 hours, rotated $180^{\circ}$ and heated for an additional 24 hours, and rinsed 3 times with Milli-Q water. January samples were collected similarly into non-acid washed LDPE bottles. Sterile flocked swabs were rubbed on rocks or solid surfaces, such as concrete weirs, that had a growing biofilm for stream sampling sites. Swabs were rubbed on surrounding surfaces (e.g. PVC piping) with growing biofilms for well sampling sites.

Stream flow measurements were made in August, 2018 at 4 locations along the Waimea River and Kamananui Stream located in Waimea Valley (Fig. 2a). Standard stream flow measuring procedures were followed according to Rantz (1982) except depths were measured 
$1 / 3$ into the water column from the water surface instead of $2 / 6$. Values were adjusted based on a conversion table in Rantz (1982) to report average velocity of the streams. Velocity measurements were recorded every 0.3 meters perpendicular to stream flow.

The velocity value for the last $1 / 3$ meter on the south margin of the Upper Waimea River site was estimated because the water depth was insufficient for the flow meter to accurately record a velocity. $500 \mathrm{ml}$ of water was collected at all stream flow measuring sites and 18-KRM20 for tritium analysis (Fig. 2a). Samples were collected by lowering a closed, opaque bottle 5 $\mathrm{cm}$ above the streambed, with the bottle opening pointed upstream. The bottle was closed during the descent and ascent through the water column.

\subsection{Laboratory Methods}

Temperature, $\mathrm{pH}$, and conductivity from stream and well waters were measured in the field using an IQ instruments IQ170 $\mathrm{pH}$ and conductivity meter equipped with a temperature compensating ion-sensitive field-effect transistor (ISFET) $\mathrm{pH}$ probe and a Bull's-eye conductivity probe. Anion concentrations were measured at Brigham Young University (BYU) using a Dionex ICS-90 ion chromatograph. Bicarbonate values were measured using a $\mathrm{HACH}$ Digital Titrator. Samples were refrigerated until analysis and performed within 1 week of sample collection. Cation concentrations were measured at BYU using a Thermo Scientific iCAP 7000 series inductively coupled plasma optical-emission spectrometer (ICP-OES). February stream samples exceeded calibration standards for silica, and were diluted 1:10 with Milli-Q water, and reanalyzed.

$\delta^{18} \mathrm{O}$ and $\delta \mathrm{D}$ were analyzed at BYU using a Los Gatos liquid water isotope analyzer (model LWIA-24d). TOC in stream and well water samples were measured at BYU using a Shimadzu TOC-L SCH total organic carbon analyzer. ${ }^{3} \mathrm{H}$ analysis was performed following methods in 
Nelson et al. (2013). Scintillation counting was performed with a PerkinElmer Quantulus liquid scintillation spectrometer at BYU.

Soil $\mathrm{pH}$ was measured at BYU by insertion of an ISFET $\mathrm{pH}$ probe attached to an IQ instruments IQ170 $\mathrm{pH}$ and conductivity meter into approximately $15 \mathrm{ml}$ of soil dampened with Milli-Q water until the sample glistened and the pore spaces were filled. HVO samples with ample material were crushed with a tungsten carbide SPEX ShatterBox. Samples with less than 70 grams of material were crushed in a SPEX, tungsten carbide grinding vial set. Soil mineralogy was analyzed at BYU using a Rigaku MiniFlex600 X-ray diffractometer (XRD) with $\mathrm{Cu}$ radiation and a step scanning rate of $0.02^{\circ} 2 \Theta /$ second. Samples were scanned from $5-65^{\circ} 2 \Theta$ on zero-background holders. Mineral abundances were estimated using the Rietveld method embedded in the PDXL 2 software package (Rigaku). Soil samples containing halloysite or kaolinite were treated with formamide based on methods from Churchman (1984) and reanalyzed from $5-15^{\circ} 2 \Theta$ at a rate of $0.02^{\circ} 2 \Theta /$ second.

Loss on Ignition (LOI) testing was performed for HVO samples. Air dried and crushed samples were heated to $100^{\circ} \mathrm{C}$ for 4 hours and approximately two grams of material was placed in pre-ignited ceramic crucibles (i.e. crucibles were heated to $1000^{\circ} \mathrm{C}$ and cooled in an anhydrite-filled desiccator for 30 minutes before material was added). Crucible and sample + crucible weights were weighed using a Mettler AE 50-S scale with $\pm 0.0001 \mathrm{~g}$ precision. Crucibles were placed in an oven at $400^{\circ} \mathrm{C}$ for 2 hours to remove organic material, cooled in an anhydrite-filled desiccator for 30 minutes, and weighed. Following the $400^{\circ} \mathrm{C}$ calcination step, crucibles were placed in an oven at $1000^{\circ} \mathrm{C}$ for 2 hours to remove any remaining water and carbonate material, cooled in an anhydrite-filled desiccator for 30 minutes, and weighed. 
Major element abundance analyses were performed following methods in Nelson et al. (2013) and were measured on a Rigaku ZSX Primus II X-ray fluorescence spectrometer (XRF) at BYU. Past experience has shown that clay- and organic-rich soils evolve gases from pressed pellets, preventing sufficient vacuum from being achieved in the XRF. This was avoided by calcining all samples for both major and trace elements. Reported abundances have been recalculated to account for LOIs.

Pyrolysis of the soil samples was performed using a Wildcat Technologies HAWK Workstation. Approximately 50 milligrams of sample material was placed into a crucible. Samples had 3 steps of heating at $100^{\circ} \mathrm{C}, 650^{\circ} \mathrm{C}$ to measure organic carbon content, and $850^{\circ} \mathrm{C}$ to measure inorganic carbon content. Temperatures dropped to approximately $125^{\circ} \mathrm{C}$ between the $650^{\circ} \mathrm{C}$ and $850^{\circ} \mathrm{C}$ heating steps. Helium and hydrogen were used as carrier gases alternating at different stages of the pyrolysis. Bacterial analyses were performed at National Jewish Health using rpoB and/or $16 \mathrm{~S}$ gene sequencing of bacterial isolates cultured from the soil and stream biofilm samples.

\subsection{Numerical Methods}

\subsubsection{Soil Composition Modeling}

$\tau$ (Greek letter tau) values quantify leaching of mobile elements in each sample relative to $\mathrm{TiO}_{2}$ or other immobile elements or oxides. $\tau$ values were calculated for HVO soil samples based on the average of $\mathrm{HVO} 229,230$, and 231 for $\mathrm{TiO}_{2}$ (i.e. fresh basalt cinders) following methods from Brantley and White (2009). The following equation presents the $\tau$ calculations:

$$
\tau=\frac{C_{j, w} C_{i, p}}{{ }_{j, p} C_{i, w}}-1
$$


Where $\mathrm{C}_{\mathrm{j}, \mathrm{w}}$ and $\mathrm{C}_{\mathrm{i}, \mathrm{w}}$ are concentrations of constituent $j$ (e.g. $\mathrm{SiO}_{2}, \mathrm{MgO}$, etc.) and the immobile constituent $i$ (e.g. $\mathrm{TiO}_{2}$ ). The subscript $p$ represents the parent constituent and $w$ represents the comparative sample. A positive $\tau$ value indicate addition to the soil of a particular oxide or element and a negative $\tau$ value indicates oxide or element loss. Values were multiplied by 100 to represent the percentage leached or enriched.

Organic matter percentages for the 2012 soil dataset were not measured in this study. However, an interpolated database, maintained by the University of Hawaii (Deenik et al., 2014), was used to extract estimated organic matter values for each sample location using ArcGIS Pro. Additionally, an interpolated soil type database, maintained by the University of Hawaii (Deenik et al., 2014), was used to extract soil orders for each sample location using ArcGIS Pro. These soil orders were used for classification purposes only and were not used as a variable for statistical analysis.

\subsubsection{Statistical Methods}

Four statistical methods were implemented in this study to gain a broad understanding of the geochemical factors controlling NTM occurrence. To gain an idea of the variables that were correlated to NTM presence or absence, 2 sample, univariate, Kolmogorov-Smirnov testing was performed. This method evaluated the difference between samples with and without NTM of a single variable (e.g. TOC, $\mathrm{pH}$, etc) and quantitatively determined the likelihood that the two sample sets came from the same, continuous population (null hypothesis), or different populations (alternative hypothesis), with the $p$-value indicating the probability that it would be a mistake to reject the null hypothesis. Kolmogorov-Smirnov tests are similar to Student's t-tests, except that t-tests determine the likelihood that the means of sample sets are the same or different, and they assume normal distributions. Kolmogorov-Smirnov tests assume no particular 
distribution shape. Principal component analysis (PCA) and non-metric multidimensional scaling (NMDS) were tools used to determine ways to statistically distinguish between samples with and without NTM, using combinations of all the variables in a given dataset. These methods can also inform the user what variables contribute to the statistical separation of samples with and without NTM. PCA measures Euclidean distances to create correlations between the variables to reduce the number of dimensions and explain most of the variance in the first few dimensions. NMDS is a very similar ordination method that also measures the Euclidean distance between the variables, but also ranks those distances highest to lowest. The rank orders are compared against the rank orders of an initial guess ordination and samples are iteratively adjusted in a direction that reduces stress. Although PCA and NMDS analyses were similar, both were used to compare outputs given that NTM geochemical correlations are relatively unexplored. Logistic regression was a method used to quantify the probability of NTM presence given a value of a single variable (e.g. $4 \%$ TOC, $20 \mathrm{mg} / 1 \mathrm{HCO}_{3}^{-}$, etc.).

Fragmentary mineralogical data limited the HVO PCA, NMDS, and logistic regression analyses to Fe oxides, mafic silicates (e.g. olivine and pyroxene), and feldspar. Other minerals in the HVO samples included clays, carbonates, goethite, and ilmenite. Minerals were grouped to limit variable size in the regression analysis and thus in the PCA and NMDS analyses for consistency. Similar fragmentation issues limited the 2012 mineralogical dataset to carbonate, gibbsite, feldspar, quartz, clays, goethite, and Fe oxides. The 2012 and HVO datasets were modeled using a generalized linear model in R. The 2018 stream dataset had insufficient data to meet model assumptions. After an initial model was developed, model selection was employed and the models with a weight greater than $1 \%$ were evaluated. The models were ranked by the Akaike Information Criterion (AIC), which value estimates the quality of each statistical model 
(Akaike, 1973). Variables that existed in the top models were model averaged. Model averaging finds the mean of each variable's values and uses zero when a variable was not included in a model. More weight is given to variable values in higher AIC ranked models. Model averaged coefficients and standard errors were then obtained. PCA and NMDS analyses were evaluated for separation between samples with and without NTM for the first 10 dimensions or axes of the 2012 soil dataset and the 2018 Kilauea soil dataset. Due to limited variables, the 2018 water dataset was only evaluated for the first 6 dimensions or axes. Kolmogorov-Smirnov tests were performed for the NTM present and NTM absent datasets for PCA axes 1 and 2 and NMDS axes 1 and 2 for all 3 datasets. PCA axis 6 was tested for the stream dataset based on an improved grouping of samples with and without NTM.

\subsubsection{Groundwater Modeling}

This study's numerical groundwater flow model was modified from an existing Oahu NAVFAC groundwater flow model (Rotzoll and El-Kadi, 2007). The NAVFAC model was updated from Oahu's Source Water Assessment Program (SWAP) model (2010) by including modern pumping well rates, observed water levels, and land use from 1996-2005. The SWAP and NAVFAC models both used a two-layer model to represent the confining effects of sedimentary caprock on the fringes of the island. Due to a negligible caprock influence at Waimea Bay, this study used a single layer model that was converted to a three layer model after calibration for particle tracking analyses. The bottom of layers 1 and 2 were assigned elevations based on the well screen elevations for wells 3803-01 and 3803-03 (Fig. 2a) (i.e. layer 2 was generally as thick as the 2 well screens).

This model was run using the MODFLOW 2000 version in Aquaveo's Groundwater Modeling System (GMS) software with the Layer Property Flow package. The Preconditioned 
Conjugate Gradient solver was used in all stages of modeling. The model grid was rotated $45^{\circ}$ counter-clockwise to orient the model according to the direction of flow (e.g. SE to the NW). The grid consists of 106 cells parallel to the coast and 117 cells perpendicular to the coast with a total of 7,726 active cells in the 1-layer model and 23,178 active cells in the 3-layer model (Fig. 2b). A grid refinement was a method used to create smaller cells around wells to observe finer details. This method was performed around the pumping wells with a base cell size of $30 \mathrm{~m}$ and a max cell size of $150 \mathrm{~m}$. Cell sizes increased or decreased no more than 1.1 times the neighboring cells. The grid top elevation was interpolated to a $10 \mathrm{~m}$ DEM and the grid bottom elevation was interpolated to a scatter point set representing the freshwater/saltwater interface according to the Ghyben-Herzberg ratio (Verruijt, 1968). Hydraulic conductivity values that were used in this study were similar to the NAVFAC report. The caprock conductivity was simulated in this model by using the equivalent value of the caprock and underlying basalt. The caprock conductivity is in the upper range of the NAVFAC model caprock conductivity because this study used a 1-layer initial calibrated model and Rotzoll and El-Kadi (2007) used a 2-layer model with differing conductivities for layers 1 and 2 . This study's caprock conductivity calculation was based on the relative caprock thickness according to local well logs and conductivities shown by the NAVFAC study and local well logs (University of Hawaii at Manoa, 2012). The caprock zone of hydraulic conductivity consists of sedimentary deposits and lies near the coast and basalt bedrock is up-gradient in the model area (Fig. 2b).

Boundary locations were chosen based on aquifer divisions established in previous studies (Mink and Lau, 1990). Specified flux boundaries are instances in which a certain volume of groundwater is injected into the aquifer. Specified head boundaries are instances where the boundary is set to a certain head value and water either exits the model or is injected into the 
model based on heads near the boundary. The eastern and southern boundaries of the model were set as specified flux boundaries based on the flow budget values from the NAVFAC model (Fig. 2b). The coastal boundary was modeled as a specified head of zero. The coastal boundary was modeled as a specified head boundary versus specified flux to not over-constrain the model. Recharge values for this study were based on recharge values in the NAVFAC model with increasing recharge zones up-gradient from the coast (Fig $2 b$ ).

A major addition to the NAVFAC model involved the addition of the Waimea stream and stream flow. Flow measurement methodology was mentioned previously. The thickness of the stream bottom sediment was estimated based on well logs and previous studies (Mink and Lau, 1980; Hunt Jr., 1996; Hampton et al., 2004; University of Hawaii at Manoa, 2012; Lautze and Thomas, 2012). Conductance of the river bed sediments is defined as:

$$
C=\frac{k A}{M}
$$

Where $\mathrm{C}$ is the conductance, $\mathrm{k}$ is hydraulic conductivity of the river bed sediments, $\mathrm{A}$ is the length of the river by the width of the river, and $\mathrm{M}$ is the thickness of the river bed sediments. A lower conductance was used downstream of the upper Waimea flow measure site and a higher conductance upstream of the upper Waimea flow measure site (Fig. 2a). The volume of water lost to the aquifer was similar between the upper and lower Waimea sites interval and the lower Kamananui and upper Waimea site interval. However, the downstream interval was $950 \mathrm{~m}$ and the upstream interval was $150 \mathrm{~m}$. Thus, the lower interval needed a lower conductance to properly calibrate the model. The reasoning behind a lower conductance could be due to the caprock in the downstream interval limiting flow. Another addition to the NAVFAC model was the incorporation of ephemeral tributaries to the main Waimea stream. These ephemeral 
tributaries were represented as drains in MODFLOW. The conductance value for the drains was adjusted until it approximately matched the volume of water discharging into the aquifer from the stream.

The NAVFAC model pumping wells were not used in this model because the volume being pumped was insignificant compared to the other inputs and outputs of the flow budget. Also, the location of the NAVFAC pumping wells were near the coast on the northeast and southwest fringes of the model. Wells 3803-01 and 3803-03 were given a pumping rate of $378 \mathrm{~m} / \mathrm{d}$ and $757 \mathrm{~m}^{3} / \mathrm{d}$, respectively, after calibration according to maximum water right allotments (University of Hawaii at Manoa, 2012). Observation wells for this study were identical to the observation wells used for the NAVFAC model and incorporate head values from 1996 to 2005.

The goal for calibration was to match heads at observation wells within $0.61 \mathrm{~m}$ (i.e. $2 \mathrm{ft}$ ) while calibrating to flow values $\pm 5 \%$. Calibration was determined by head and flow errors (i.e. observed vs. computed). Root mean squared (RMS) and sum of square weighted residual (SSWR) errors were used to compare observed vs. computed head and flow values. RMS values were produced for both head and flow, whereas, SSWR values are head + flow. The following equations describe these errors:

$$
\begin{gathered}
\text { RMS Error }=\sqrt{\frac{1}{n} \sum_{i=1}^{n}(o-c)_{i}^{2}} \\
\text { SSWR Error }=\sum_{i=1}^{n_{h}}\left(h_{o}-h_{c}\right)_{i}^{2}+\sum_{j=1}^{n_{f}}\left(f_{o}-f_{c}\right)_{j}^{2}
\end{gathered}
$$

Where $n$ is the number of observations, $o$ is observed head or flow values, $c$ is computed head or flow values, $n_{h}$ is number of head observations, $h_{o}$ is observed head values, $h_{c}$ is computed head 
values, $n_{f}$ is number of flow observations, $f_{o}$ is observed flow values, and $f_{c}$ is computed flow values. $n_{f}$ is 3 and $n_{h}$ is 6 for the models in this study.

As mentioned above, after the initial calibration, the model was split into three layers in order to accurately depict flow paths or capture zones for the two Waimea Valley pumping wells and their specific screened elevations. The 3-layer model had the same caprock value in the same lateral locations, which conductivity values were then applied to all 3 layers (Fig. 2b). The addition of multiple layers required the evaluation of multiple models with differing horizontal to vertical conductivity ratio (i.e. $\mathrm{Kh} / \mathrm{Kv}$ ) values of 20 and 200. Both were performed with a porosity value of $5 \%$ that was used across the model extent.

A brief exploration of uncertainties in horizontal conductivity and recharge was also evaluated to understand model sensitivity. These parameters are generally the most sensitive in a groundwater model and they are difficult to measure. Two models were constructed for minimum and maximum values of recharge and hydraulic conductivity. Both models used a $\mathrm{Kh} / \mathrm{Kv}$ ratio of 20 . Upper and lower bounds of uncertainty were established for recharge based on data from a comprehensive database (Frazier et al., 2016). Upper and lower bounds of uncertainty were established for hydraulic conductivity based on previous research and the NAVFAC model (Mink and Lau, 1980; Rotzoll and El-Kadi, 2007). Additionally, Geochemical modeling of August stream samples were performed in the Geochemist's Workbench (GWB).

\section{RESULTS}

\subsection{NTM Results}

NTM culturing and DNA sequencing results have been completed for the 2012 soil dataset and DNA sequencing only for the HVO soil dataset. DNA sequencing results are incomplete, but 
in progress for the 2018 Oahu dataset. Seven of 512018 Oahu streams (e.g. the 7 NTM analyzed streams are from the January sampling) have been DNA sequenced for NTM and no 2018 Oahu soil samples have been cultured or DNA sequenced for NTM at this time.

\subsection{Hawaii 2012 Soil Dataset}

\subsubsection{Chemical Results}

The 2012 dataset consisted of samples across the Hawaiian Islands with a heavy sampling emphasis on Oahu ( $n=39 / 51)$. Thus, mineralogy was primarily composed of secondary minerals (e.g. Fe-Ti oxides/hydroxides and clays). Feldspar, pyroxene, and olivine were also present across the islands, but in smaller abundances than the HVO dataset and in dry regions only. After diffraction patterns were acquired, mineral abundances below an assumed detection limit of 3 weight $\%$ were assigned a value of 1 weight $\%$ to maintain comprehensive datasets for PCA, NMDS, and logistic regression analyses. 2012 Hawaii soil $\mathrm{pH}$ values ranged from 4.0 to 8.0 with an average of 7.0 and median of 7.3.

\subsubsection{Statistical Results}

For PCA and NMDS analyses, the 2012 dataset contained mineralogy, $\mathrm{pH}$, interpolated organic matter, and interpolated precipitation. For the logistic regression, the precipitation value was removed due to model degradation (discussed below). The NTM culture data (e.g. NTM colony forming unit (CFU) counts) were not used due to unmet assumptions for the residual distribution. Instead, logistic regression required NTM presence or absence based on DNA sequence data.

The 2012 PCA showed no significant separation (Fig. 3g). Additionally, the first and second principal component axes explained only $24 \%$ and $19 \%$ (43\% total) of the variance, respectively. 
Kolmogorov-Smirnov testing showed no statistically significant difference between NTM presence vs. absence with p values of 0.85 and 0.59 for PC axes 1 and 2, respectively. Variables included in the PCA were feldspar, carbonate, quartz, soil pH, rainfall, organic matter, gibbsite, goethite, Fe oxides, and clays.

Similar to the 2012 PCA, results from the 2012 NMDS analysis showed no significant separation of NTM presence vs. absence. Additionally, there was overlapped groupings of soil types. Kolmogorov-Smirnov testing showed no statistically significant difference between NTM presence vs. absence with $\mathrm{p}$ values of 0.69 and 0.61 for MDS axis 1 and MDS axis 2, respectively (Table 2).

The 2012 logistic linear regression results show 33 models with a weight greater than $1 \%$ (Table 3a). The weight multiplied by 100 represents the probability of each model being the correct or representative model. The total weight for the top 33 models is $86 \%$. Feldspar appeared 16 times in the top 33 models and goethite, gibbsite, and organic matter were in the top models only 12 times. Fe oxide and $\mathrm{pH}$ appeared only 9 times in the top models. No variables were collinear or had an $\mathrm{R}^{2}$ value over 0.6 (i.e. cutoff for collinearity) (Nagelkerke, 1991). The 95\% confidence intervals all span zero (Table $3 \mathrm{~b}$ ). Feldspar and the intercept had an overlap of less than 1.5 standard deviations away from zero. Gibbsite, organic matter, goethite, $\mathrm{pH}$, and $\mathrm{Fe}$ oxides overlapped zero between 1.5 and 1.9 standard deviations. The $\mathrm{pH}$ and Fe oxide coefficients were very near zero and both upper and lower limits straddled zero almost equally (e.g. 1.9 standard deviations). Additionally, the Kolmogorov-Smirnov tests showed no statistically significant separation of NTM presence vs. NTM absence in any of the variables in this dataset (Table 2). 


\subsection{Oahu 2018 Dataset}

\subsubsection{Oahu 2018 Soils}

\subsubsection{Chemical Results}

The 2018 Oahu soil dataset was composed mainly of secondary minerals (e.g. Fe, Al, and Ti oxides and hydroxides and clays) with lesser amounts of primary minerals (e.g. olivine, plagioclase, and quartz). Some samples contained minor amounts of carbonate minerals (e.g. calcite/aragonite ratio of 4.6:1) that were likely soil additives as pedogenic carbonate is rare in Hawaii, especially in mesic to wet areas. Sample 8 showed a different mineralogical signature than the majority of the Oahu samples, which location and minerals suggest this is due to rejuvenated, alkalic, Honolulu Series eruptions (Fig. 1a). Specifically, this sample is most likely part of the Tantalus member (Gramlich et al., 1971). 2018 Oahu soil pH values ranged from 5.0 to 7.9 with an average of 6.5 and median of 6.4 . Samples $6,9,11,12,18,19$, and 20 (i.e. generally the leeward side of the Ko'olau Range) were more acidic in the summer (e.g. August

samples, 18-KRM-\#) and samples 1, 2, 3, 4, 5, 7, 8, 10, 13, 14, 15, 16, and 17 (i.e. generally the windward side of the Ko'olau Range) were more basic in the winter (e.g. January and February samples, 18-STR-\# and 18-KAR-\#). Additionally, pyrolysis results showed a TOC range of 0.4 to 11.3 with an average of 3.8 and median of 3.3 .

\subsubsection{Statistical Results}

Due to the lack of bacterial results for 2018 Oahu soils, statistical analyses have not been performed on this dataset.

\subsubsection{Oahu 2018 Streams}

\subsubsection{Chemical Results}


Water chemistry results for the 2018 Oahu stream samples showed similar values to a recent comprehensive water study (Nelson et al., 2013). Groundwater samples 4 and 5 generally had higher concentrations than the majority of surface water samples. This result agrees with previous solute work on Oahu stating that groundwater solutes are higher than surface water (Nelson et al., 2013). August samples 18-KRM-18, 18-KRM-4, 18-KRM-13, 18-KRM-5, 18KRM-9, 18-KRM-2, 18-KRM-14, 18-KRM-15, 18-KRM-16, 18-KRM-3, and 18-KRM-7 had the highest Total Dissolved Solids (TDS) values (Fig 1b), from highest to lowest, of $324 \mathrm{mg} / \mathrm{l}$ and $88 \mathrm{mg} / \mathrm{l}$ for samples 18-KRM-18 and 18-KRM-7, respectively (Fig. 4). The highest TDS samples generally were located in high precipitation areas on Oahu and the lower TDS samples were located in areas with less precipitation, which result is also shown by Chadwick et al. (2003) and Nelson et al. (2013). Additionally, Nelson et al. (2013) observed elevated $\mathrm{Cl}^{-}$ concentrations in arid regions due to atmospheric deposition of sea salts, which observation is similarly made in this study (i.e. samples with lower TDS in this study are associated with higher $\mathrm{Cl}^{-}$) (Fig. 4).

$\mathrm{Al}$ and $\mathrm{Fe}$ oxides and hydroxides (e.g. goethite and hematite), smectite clays (e.g. beidellite and nontronite), and K-feldspars were the dominant over saturated minerals in the August sampled streams according to GWB modeling in the SpecE8 application. January and February samples showed very similar water chemistry. Although smectite clays were modeled over saturated, smectite clays were rarely observed in soils from associated stream banks. Hematite and Goethite were both oversaturated in all Oahu August 2018 water samples except 18-KRM-4. These minerals were commonly observed in stream bank soils. Complete water chemistry for the 2018 Oahu samples is shown in Appendix A. 
Out of the 4 stream sites analyzed for tritium, 3 sites had a value of 1 tritium units (TU) and 1 had a value of $0.9 \mathrm{TU}$. The lower Waimea discharge measuring site had the $0.9 \mathrm{TU}$ value and the 3 sampling sites in the middle (e.g. upper Waimea, lower Waimea, and 18-KRM-20) had the values of $1 \mathrm{TU}$ (Fig. 2a). Tritium results imply that the age of the stream water ranges from 1965 to the present (Fig. 5). These values are consistent with Nelson et al. (2013) findings. $\delta^{18} \mathrm{O}$ and $\delta \mathrm{D}$ isotopic ratios were typical of Hawaiian waters and were enriched with respect to global meteoric water (Craig, 1961). Values for $\delta^{18} \mathrm{O}$ ranged from $-3.8 \%$ to $-1.5 \%$ and values for $\delta \mathrm{D}$ ranged from $-12.0 \%$ to $0.7 \%$. Generally, $\delta^{18} \mathrm{O}$ and $\delta \mathrm{D}$ values were depleted on the windward side of the island and enriched on the leeward side of the island. This trend is expected for the higher precipitation, windward $\delta^{18} \mathrm{O}$ and $\delta \mathrm{D}$ values due to depletion of heavy isotopes with increased rainfall. The windward, increased rainfall is due to the orographic effect of the Ko'olau Mountains combined with the trade wind direction to the south west.

\subsubsection{Statistical Results}

For PCA, NMDS, and logistic regression analyses, the Oahu 2018 stream dataset contained TOC, $\mathrm{pH}$, and a suite of major and trace elements. Logistic regression required NTM presence or absence based on DNA sequence data.

Although the PC 1 and 2 axes showed a clear separation between NTM presence vs. NTM absence, the separation was more distinct between PC 1 and 6 axes. Figure $3 \mathrm{e}$ showed that the small stream order, NTM present samples correlated with the positive PCA 6 axis and the negative $\mathrm{PC} 1$ axis. $\mathrm{Mg}^{2+}, \mathrm{Na}^{+}, \mathrm{Cl}^{-}, \mathrm{Ba}, \mathrm{Co}, \mathrm{Cr}, \mathrm{Li}, \mathrm{Mo}, \mathrm{Ni}$, and $\mathrm{Zn}$ explain $53 \%$ of the variance on the principal components 6 axis, which axis explains $4.3 \%$ of the total variance. Additionally, Figure $3 \mathrm{f}$ shows better separation of elements on the PC 6 axis than the PC 2 axis in Figure $3 \mathrm{~d}$. $\mathrm{Ca}^{2+}, \mathrm{Mg}^{2+}, \mathrm{Na}^{+}, \mathrm{K}^{+}, \mathrm{HCO}_{3}{ }^{-}, \mathrm{F}^{-}, \mathrm{Cr}, \mathrm{Mo}, \mathrm{Sr}$, and $\mathrm{V}$ explain $51 \%$ of the variance in the principal 
components 1 axis, which axis explains $37 \%$ of the total variance. Figure $3 f$ shows that $\mathrm{Zn}, \mathrm{Li}$, $\mathrm{Na}^{+}$, and $\mathrm{Cl}^{-}$control the positive PCA 6 axis or NTM presence grouping and Mo, Cr, and Ni control the negative PC 1 axis or NTM presence grouping. $\mathrm{Mg}^{2+}$ and $\mathrm{Ba}$ control the negative PCA 6 axis and $\mathrm{HCO}_{3}{ }^{-}, \mathrm{Ca}^{2+}, \mathrm{F}^{-}, \mathrm{Mg}^{2+}$, and $\mathrm{Sr}$ control the positive PCA 1 axis. KolmogorovSmirnov testing for PC axes 1 and 6 showed a statistically significant difference between NTM presence vs. absence with p values of 0.04 and 0.04 (Table 2). There was not a statistical significance for the NTM presence vs absence for PC axis 2 , which $\mathrm{p}$ value was 0.48 . The stream NMDS results were similar to the PCA analysis, except the NMDS plot was a mirror image (i.e. transformation across both axes) of the PCA plot (Fig. 6a). Kolmogorov-Smirnov testing showed no statistically significant difference between NTM presence vs. absence with p values of 0.47 and 0.91 for MDS axis 1 and MDS axis 2, respectively (Table 2). Considering both PCA axes (e.g. 1 and 6) are statistically significant, but the NMDS axes are not statistically significant, the PCA analysis will be given further attention.

Although the stream dataset was not modeled with logistic regression due to the lack of data, Kolmogorov-Smirnov univariate statistics were performed on the chemical data and $\mathrm{Mg}^{2+}$ and $\mathrm{SO}_{4}{ }^{2-}$ showed the only statistically significant distribution uniqueness with $\mathrm{p}$ values of $0.04 . \mathrm{pH}$, $\mathrm{F}^{-}, \mathrm{Ba}, \mathrm{Li}, \mathrm{Mn}, \mathrm{Sr}, \mathrm{Ti}$, and $\mathrm{Zn}$ had the next highest $\mathrm{p}$ values of 0.16 (Table 2).

\subsection{HVO 2018 Soil Dataset}

\subsubsection{Chemical Results}

HVO soil mineralogy was primarily olivine, pyroxene, and feldspar with minor amounts of Fe, Al, and Ti oxides and hydroxides (e.g. goethite, hematite, ilmenite, maghemite, and magnetite). HVO samples 23 and 224 showed minor gypsum peaks in the diffraction patterns. HVO soil $\mathrm{pH}$ values ranged from 3.6 to 7.8 with an average of 5.0 and median of 4.8. Results 
from the $\mathrm{HVO} \tau$ values show that the immobile oxides (e.g. $\mathrm{SiO}_{2}, \mathrm{Fe}_{2} \mathrm{O}_{3}$, and $\mathrm{Al}_{2} \mathrm{O}_{3}$ ) are near 0 (Fig. 7a) as expected. However, the more mobile oxides (e.g. $\mathrm{MgO}, \mathrm{CaO}, \mathrm{Na}_{2} \mathrm{O}$, and $\mathrm{K}_{2} \mathrm{O}$ ) vary much more (Fig. 7b). The evergreen forest samples show the largest range of $\mathrm{MgO}$ enrichment and depletion and the largest $\mathrm{K}_{2} \mathrm{O}$ depletion values. The bare rock sample, 232, has the largest depletion values for $\mathrm{Na}_{2} \mathrm{O}$ and $\mathrm{CaO}$. Sample 238, in the evergreen forest, showed a $\mathrm{Fe}_{2} \mathrm{O}_{3}$ enrichment spike with a $\tau$ value near $3 . \mathrm{P}_{2} \mathrm{O}_{5}$ was generally enriched in all samples. Evergreen forest samples had a much lower enrichment of $\mathrm{P}_{2} \mathrm{O}_{5}$.

Figures 8a and 8c have plotted a standard USGS basalt (BHVO-1) collected in 1919 from the Halemaumau crater as a reference point (Flanagan, 1976). Figures 8b and 8d lack the BHVO-1 sample assuming it has a similar reference point as samples HVO 229, 230, and 231 (e.g. samples that were averaged for the $\mathrm{C}_{\mathrm{i}, \mathrm{p}}$ and $\mathrm{C}_{\mathrm{i}, \mathrm{w}}$ components in equation 1). The BHVO-1 sample plots similarly to this study's samples (Figs. 8a and 8c). Soil samples HVO 219, 221, 222, 224, 226, 235, and 236 did not have sufficient material after calcination for major and trace element analysis. Full HVO soil chemistry and mineralogy is in Appendix B.

HVO soil pyrolysis results showed a range of hydrogen index (HI) values from 12 to 468 $\mathrm{mgHC} / \mathrm{gTOC}$ with an average of $179 \mathrm{mgHC} / \mathrm{gTOC}$ and median of $205 \mathrm{mgHC} / \mathrm{gTOC}$. Oxygen indices (OI) revealed a range of values from 65 to $272 \mathrm{mgCO}_{2} / \mathrm{gTOC}$ with an average of 115 $\mathrm{mgCO}_{2} / \mathrm{gTOC}$ and median of $101 \mathrm{mgCO}_{2} / \mathrm{gTOC}$. HI vs. OI plotted on a Van Krevelen diagram is a common practice for determining the source environments of organic matter. A recent study showed that type II organic matter (e.g. type II typically has an HI range of 100 to 600 mgHC/gTOC) represents plant tissue, whereas type I represents algal matter (Hudson et al., 2019). The HI and OI values lie within the range of the type II window, but may have some 
contributing algal matter. Additionally, pyrolysis results showed a TOC range of 0.2 to 43.1 with an average of 7.4 and median of 1.9 .

\subsubsection{Statistical Results}

For PCA, NMDS, and logistic regression analyses, the HVO 2018 soil dataset contained TOC, $\mathrm{pH}$, mineralogy, and a suite of major and trace elements and oxides. Logistic regression required NTM presence or absence based on DNA sequence data.

The HVO NMDS analysis results showed a slight positive trend and grouping of NTM present samples in the positive, positive quadrant and a tight clustering of NTM absent samples near the origin (Fig. 6b). The HVO NMDS analysis was close to a mirror image (i.e. transformation across both axes) of the PCA analysis, but there are subtle differences. Figure 6b presents separation of soil type between bare rock and andisols. The andisols grouping appears to encompass some of the bare rock grouping, but no andisol samples lie within the bare rock grouping. Axes MDS 1 and MDS 2 explain 81\%, and 11\% (92\% total) of the variance respectively. Figure $6 \mathrm{~d}$ shows that TOC, $\mathrm{pH}, \mathrm{P}_{2} \mathrm{O}_{5}$, mafic silicates (e.g. olivine and pyroxene), and $\mathrm{Pb}$ control the positive MDS 1 axis. There is a large grouping of elements and an oxide that control the negative MDS 1 axis including $\mathrm{Zr}, \mathrm{Ga}, \mathrm{Nb}, \mathrm{Y}, \mathrm{TiO}_{2}, \mathrm{Rb}$, and $\mathrm{Sr}$ as leading variables. $\mathrm{P}_{2} \mathrm{O}_{5}, \mathrm{~Pb}$, and $\mathrm{Zn}$ control the positive MDS 2 axis and $\mathrm{Cr}, \mathrm{Ni}$, and $\mathrm{MgO}$ control the negative MDS 2 axis. Sample HVO 23 is an outlier on the NMDS plot, whereas it minorly contributes to the NTM presence trend on the PCA plot (Fig. $6 \mathrm{~b}$ and Fig. 3a, respectively). KolmogorovSmirnov testing showed statistically significant difference between NTM presence vs. absence with p values of 0.005 and 0.03 for MDS axis 1 and MDS axis 2, respectively. KolmogorovSmirnov testing for PC axis 1 showed a statistically significant difference between NTM presence vs. absence with a $\mathrm{p}$ value of 0.002 (Table 2). There was not a statistical significance 
for the NTM presence vs absence for PC axis 2 , which $\mathrm{p}$ value was 0.09 . Considering both NMDS axes are statistically significant, but the PCA axes are not both statistically significant, the NMDS analysis will be given further attention.

The HVO logistic regression variables were selected according to Kolmogorov-Smirnov results (Table 2). Figure 9 shows the variables in the HVO dataset that had significant differences (e.g. $>95 \%$ ) between NTM present and NTM negative samples. Considering each variable lacked a normal distribution in the NTM present and absent sample sets, the Kolmogorov-Smirnov test was adopted in lieu of Student's t-test. Variables with a significant difference between NTM present vs. NTM absent datasets include TOC, $\mathrm{SiO}_{2}, \mathrm{Fe}_{2} \mathrm{O}_{3}, \mathrm{Sc}, \mathrm{MnO}$, $\mathrm{P}_{2} \mathrm{O}_{5}, \mathrm{TiO}_{2}, \mathrm{~V}, \mathrm{Sm}, \mathrm{Zr}, \mathrm{Cr}, \mathrm{Ga}, \mathrm{pH}$, and $\mathrm{MgO}$. P values ranged from 0.000009 to 0.86 for TOC and $\mathrm{Fe}$ oxides, respectively. $\mathrm{MgO}$ had the highest statistically significant $\mathrm{p}$ value of 0.045 . Statistically significant variables were then permutated and weighted in order to decide selection of modeled variables taking collinearity into consideration. Sample 238 was not included in population significance testing or logistic regression due to anomalous $\mathrm{Fe}_{2} \mathrm{O}_{3}$ and $\mathrm{Zn}$ values.

Table 4 a shows 3 of 4 models with a weight greater than $1 \%$. The model with only the intercept had a weight of 0 and is not shown. The total weight for the top 3 models was thus $100 \%$ and the models included TOC and $\mathrm{P}_{2} \mathrm{O}_{5}$. Both TOC and $\mathrm{P}_{2} \mathrm{O}_{5}$ were incorporated into the top weighted model, TOC in the second, top weighted model, and $\mathrm{P}_{2} \mathrm{O}_{5}$ in the third, top weighted model. The full model averaged coefficients were 0.86 and 10.09 for TOC and $\mathrm{P}_{2} \mathrm{O}_{5}$ respectively, with an intercept of -4.26 (Table $4 b$ ). Although all $395 \%$ confidence intervals span zero for the intercept, TOC, and $\mathrm{P}_{2} \mathrm{O}_{5}$, the confidence interval for the intercept and TOC spanned zero less than 0.75 standard deviations. $\mathrm{P}_{2} \mathrm{O}_{5}$ spanned zero less than 1.5 standard deviations. Not all variables were included in the model due to collinearity between TOC and the other statistically 
significant variables except $\mathrm{P}_{2} \mathrm{O}_{5}$ and $\mathrm{pH}$. $\mathrm{pH}$ was not included in the model due to poor predictability (Table 2).

\subsection{Groundwater Modeling Results}

The goal for calibrating the groundwater flow model was to replicate the flow budget generated by Rotzoll and El-Kadi (2007) while calibrating to observation wells used in the NAVFAC model and measured stream flows (e.g. Waimea stream and its tributaries), which were added in this study. Table 5 indicates that the percent differences between the NAVFAC model and this study's inputs and outputs are all less than $2 \%$. Figure 10 shows calibration results for observed vs. computed head values (Fig. 10a) and observed vs. residual head values (Fig. 10b).

As mentioned previously, the incorporation of discharge values into the model constrained the conductance values to $0.25 \mathrm{~m} / \mathrm{d}$ for the downstream flow interval between lower and upper Waimea flow measure sites and $1.85 \mathrm{~m} / \mathrm{d}$ for the upstream flow interval between lower Kamananui and upper Waimea flow measure sites.

Multiple models were implemented to represent multiple $\mathrm{Kh} / \mathrm{Kv}$ values of 20 and 200 based on published ranges in hydraulic conductivity (Souza and Voss, 1987; Rotzoll and El-Kadi, 2007). The model with a $\mathrm{Kh} / \mathrm{Kv}$ value of 200 produced a SSWR error of 28.8 with a RMS head error of $0.48 \mathrm{~m}$ and a RMS flow error of $81.79 \mathrm{~m}^{3} / \mathrm{d}$. The model with a $\mathrm{Kh} / \mathrm{Kv}$ value of 20 produced a SSWR error of 23.7 with a RMS head error of $0.44 \mathrm{~m}$ and a RMS flow error of 81.64 $\mathrm{m}^{3} / \mathrm{d}$. These errors were determined to be acceptable for the purposes of the model considering the NAVFAC model had a SSWR error of 22.4 for this region. 
Although one observation well exceeded the $0.61 \mathrm{~m}$ goal for calibration (see numerical methods), computed head values were no more than $0.7 \mathrm{~m}$ different than observed head values for both models. The residuals for both $\mathrm{Kh} / \mathrm{Kv}$ models were $-79 \mathrm{~m}^{3} / \mathrm{d}$ and $-85 \mathrm{~m}^{3} / \mathrm{d}$ (e.g. computed minus observed) for the lower and upper stream intervals (i.e. stream sections between the discharge measurements), respectively (Fig. 2a). After calibration was completed and wells 3803-01 and 3803-03 were added to the model, the head around the wells did not show substantial drawdown.

Particle tracking flow line pathways and travel times seem reasonable given an average horizontal hydraulic conductivity of $701 \mathrm{~m} / \mathrm{d}$ in the basal lens, an average horizontal conductivity of $548 \mathrm{~m} / \mathrm{d}$ in the caprock, and $\mathrm{Kh} / \mathrm{Kv}$ anisotropy values of 20 and 200 . Average recharge values were $0.0061 \mathrm{~m} / \mathrm{d}, 0.0010 \mathrm{~m} / \mathrm{d}, 0.0018 \mathrm{~m} / \mathrm{d}$, and $0.0033 \mathrm{~m} / \mathrm{d}$ from west to east for the recharge zones shown by Figure $2 \mathrm{~b}$. The particle tracking analysis for the wells shows that the starting locations of the particles mostly begin at the stream (Fig. 11d). The $\mathrm{Kh} / \mathrm{Kv}=20$ model showed that after 1 month, no particles had yet reached the stream (Fig. 11a). After 40 days, the first particles from the stream reached well 3803-01 and 3803-03 (Fig. 11b). It took 50 days for about half of pumped water to intersect well 3803-01 and for nearly all pumped water for well 3803-01 to come from the stream (Fig. 11c). After 95 days, all pumped water consisted of stream water (Fig. 1d). The average flow path length for well 3803-03 was 440 meters and the average travel time was 41 days. The fastest travel time for well 3803-03 was 34.3 days. The average flow path length for well 3803-01 was 701 meters and the average travel time was 76 days. The fastest travel time for well 3803-01 was 47.0 days. Figure 12 shows that stream water initially drops into the aquifer, particularly for well $3803-03$, then moves laterally towards the down-gradient well screens. 
As mentioned above in numerical methods, 2 models, based on the existing $\mathrm{Kh} / \mathrm{Kv}=20$ calibrated model, were used in the evaluation of model sensitivity for recharge and hydraulic conductivity. One model explored lower bound values of hydraulic conductivity and recharge, and the other model used upper bound values. Hydraulic conductivity values of $548 \mathrm{~m} / \mathrm{d}$ and 700 $\mathrm{m} / \mathrm{d}$ for caprock and basalt, respectively were used for the lower bound model. Recharge values of $0.00058 \mathrm{~m} / \mathrm{d}, 0.00095 \mathrm{~m} / \mathrm{d}, 0.0017 \mathrm{~m} / \mathrm{d}$, and $0.0031 \mathrm{~m} / \mathrm{d}$ from west to east were used as lower bound values for recharge (Fig 2b). The fastest travel times for the particle tracking using lower bound uncertainties were 47.4 days and 34.6 days for wells 3803-01 and 3803-03, respectively. Hydraulic conductivity values of $648 \mathrm{~m} / \mathrm{d}$ and $800 \mathrm{~m} / \mathrm{d}$ for caprock and basalt, respectively were used for the upper bound model. Recharge values of $0.00065 \mathrm{~m} / \mathrm{d}, 0.0011 \mathrm{~m} / \mathrm{d}, 0.0019 \mathrm{~m} / \mathrm{d}$, and $0.0035 \mathrm{~m} / \mathrm{d}$ from west to east were used as lower bound values for recharge (Fig 2b). The fastest travel times for the particle tracking using lower bound uncertainties were 43.8 days and 31.1 days for wells 3803-01 and 3803-03, respectively. Additionally, both uncertainty models show that nearly $100 \%$ of groundwater intersecting the 2 well screens originates from the up-gradient stream.

\section{DISCUSSION}

\subsection{Hawaii 2012 Soil Statistics}

\subsubsection{Soil Mineralogy}

Logistic predictive curves from the 2012 logistic regression model are not shown because of weak correlations between modeled variables and NTM presence (Table 3b). Feldspar, goethite, organic matter, gibbsite, $\mathrm{pH}$, and $\mathrm{Fe}$ oxide minerals were included in the model and a model selection analysis, where higher ranked models had lower AIC values, showed that the best model should include only the intercept (Table 3a). Rainfall did not have any statistical 
significance, degraded the model even more, and thus was not included in the regression model. Confidence intervals for model averaged coefficients were all above $1 \sigma$ with Fe oxide minerals and $\mathrm{pH}$ coefficients almost centered on 0 as mentioned above. A weak regression could be due to the uncertainty and large errors (e.g. up to $20 \%$ ) in mineralogical abundances determined by Rietveld interpretation. Also, the organic matter was extracted from an interpolated database (e.g. Hawaii Soil Atlas), which adds additional uncertainty and inaccuracy to the model (Deenik et al., 2014). Additionally, the same database showed a poor correlation between organic matter values from the above mentioned database and measured TOC values. However, with this 2012 soil dataset in hand, mineralogy alone is shown to be a poor NTM predictor based on above mentioned Kolmogorov-Smirnov, PCA, NMDS, and logistic regression analyses. This is substantial considering that NTM prefer attachment. The surface chemistry of minerals appear to not correlate with NTM attachment based on PCA and NMDS analyses, which mineral weathering contributes largely to the soil $\mathrm{pH}$. Additionally, organic matter did not play a large role. Other factors may control NTM attachment to a greater extent than mineralogy (HVO Soil discussion).

\subsection{Oahu 2018 Water Statistics}

\subsubsection{Controlling Variables Relationship with NTM}

Although the NMDS analysis better accounts for variance (e.g. $64 \%$ total variance explained in NMDS vs. 41\% explained in PCA) in the Oahu 2018 stream dataset, as mentioned above, the PCA axes were statistically significant and the NMDS axes were not. Therefore, the PCA 1 and 6 axes are used to make inferences regarding which elements promote or inhibit NTM.

Figure $3 \mathrm{f}$ shows that $\mathrm{Cr}$, Mo, and Ni control the NTM presence grouping on the PC 1 axis and $\mathrm{Zn}, \mathrm{Li}, \mathrm{Na}^{+}$, and $\mathrm{Cl}^{-}$control the NTM presence grouping on the PC 6 axis. More variance is 
explained by the PC 1 axis than the PC 6 axis, which suggests that NTM may require higher concentrations of transition metals (e.g. $\mathrm{Cr}, \mathrm{Mo}, \mathrm{Ni}$ ) as nutrients. $\mathrm{HCO}_{3}{ }^{-}, \mathrm{Ca}^{2+}, \mathrm{F}^{-}$, and $\mathrm{Mg}^{2+}$ control the positive PC 1 axis or the NTM absence grouping, suggesting that high concentrations of major cations and anions could limit NTM at a certain threshold. Additionally, $\mathrm{Mg}^{2+}$ and $\mathrm{SO}_{4}{ }^{2-}$, also major cations and anions, are contributing to the NTM absence grouping, albeit not as strongly, yet were statistically significant according to the Kolmogorov-Smirnov test (Fig. 3f). Although there appears to be a clear separation with these 7 stream samples, additional bacterial data will be needed to ensure that this clustering of NTM presence and absence is real.

Assimilable organic carbon (AOC) or reduced organic carbon concentrations are standard procedure for determining bacterial stability, however, this study measured TOC to experiment correlations with NTM as it is a simpler approach (Escobar and Randall, 2001; Vaerewijck et al., 2005). However, Figure $3 \mathrm{f}$ did not show TOC as an influential variable given this sample size. Vaerewijck et al. (2005) suggested that NTM growth in water is determined by more than geochemical differences. The turbidity of the water, residence time, and growth medium properties such as porosity, composition, and roughness are all additional parameters that control NTM growth that are not comprehensively evaluated in this study and could affect results.

\subsubsection{Future Water Sampling}

TDS, as mentioned above, varies between the wet and dry portions of the island. Given that major cation and anions appear to correlate with NTM absence, a simple sampling model could entail collecting water samples and NTM swabbing along 2 Oahu streams. 1 stream might be on the east side or windward side of the Ko'olau Range and 1 on the west to compare differing TDS concentrations. Other sampling approaches might involve analysis of TOC vs. AOC (i.e. reduced 
carbon) as well as a detailed analysis of biofilm attachment surfaces and stream bed characteristics (i.e. roughness, porosity, composition, etc.).

\subsection{HVO 2018 Soil Statistics}

\subsubsection{Soil Variability}

There is some scatter of $\tau$ based on the selection of fresh material (e.g. the average of samples HVO 229, 230, and 231). If a particular soil had a different parent, the $\tau$ calculation would produce apparent enrichments and depletions. Most $\mathrm{HVO}$ soil samples had $\mathrm{SiO}_{2} \tau$ values that were approximately zero, however, suggesting that little silicate mineral leaching has occurred as expected (Fig. 7a). Although little $\mathrm{SiO}_{2}$ has been leached, $\mathrm{MgO}$ varies widely from $50 \%$ depleted to over $100 \%$ enriched (Fig. $7 \mathrm{~b}$ ). $\mathrm{MgO}$ was depleted in samples with a land type classification of evergreen forest except for sample 225 , which was enriched $110 \%$. This enrichment of $\mathrm{MgO}$ as well as enrichments in $\mathrm{SiO}_{2}, \mathrm{Fe}_{2} \mathrm{O}_{3}$, and $\mathrm{Al}_{2} \mathrm{O}_{3}$ for sample 225 with respect to other evergreen forest samples may be due to the close proximity to the Keanakako'I crater due to ash (Fig. 1a). Volcanic Ash, or volcanic glass, has been shown to be enriched in $\mathrm{Fe}$ and $\mathrm{Al}$ in the form of gels (Eggleton et al., 1987; Sowards et al., 2018). However, sample 232 was collected from the south rim of the main Halema'uma'u crater and is the most depleted sample in $\mathrm{Al}_{2} \mathrm{O}_{3}$ and $\mathrm{Fe}_{2} \mathrm{O}_{3}$. Sample 232 may have increased leaching of these elements due to acid rain and $\mathrm{SO}_{2}$ emissions that are thought to contribute to the soil acidity around Kilauea (Nachbar-Hapai et al., 1989). Additionally, previous studies have shown areas around Kilauea to have similar $\mathrm{Fe}_{2} \mathrm{O}_{3} \tau$ leach values (Wolfe and Morris, 1996). The substantial $\mathrm{Fe}_{2} \mathrm{O}_{3}$ enrichment peak for HVO 238 could perhaps be similarly explained.

Figure 8a suggests that as $\mathrm{SiO}_{2}$ is leaching from the system, $\mathrm{Al}_{2} \mathrm{O}_{3}$ and $\mathrm{Fe}_{2} \mathrm{O}_{3}$ are also leaching. However, the 5 low $\mathrm{SiO}_{2}$ weight percent samples have high organic and water content, 
indicating that the $\mathrm{Fe}_{2} \mathrm{O}_{3}$ and $\mathrm{Al}_{2} \mathrm{O}_{3}$ weight percentages are diluted, in a relative sense, for those samples. The $\tau$ values shown in Figure $8 \mathrm{~b}$ account for the dilution trend, which confirms the previous idea by showing a tight cluster and no strong leaching trend. Sowards et al. (2018) noted that older Kohala samples are enriched in $\mathrm{Al}_{2} \mathrm{O}_{3}$ and $\mathrm{Fe}_{2} \mathrm{O}_{3}$ when $\mathrm{SiO}_{2}$ is leached, however, that trend is not shown in this study. There has likely not been enough time (i.e. the soils are too young) for $\mathrm{SiO}_{2}$ leaching around Kilauea and therefore a lack of $\mathrm{Fe}$ and $\mathrm{Al}$ enrichment. Figures $8 \mathrm{~b}$ and $8 \mathrm{~d}$ show an outlier sample (e.g. HVO 225) with a $\mathrm{SiO}_{2} \tau$ enrichment near $45 \%$. With the exception of $\mathrm{HVO} 23$, all soil samples with a $\mathrm{P}_{2} \mathrm{O}_{5} \tau$ enrichment greater than 1 had high LOI values (e.g. $>25 \%$ ). The $\mathrm{P}$ enrichment may be due to organic and inorganic $\mathrm{P}$ from plant material that was left behind and enriched after calcination. The bare rock HVO soil samples have $\mathrm{P}_{2} \mathrm{O}_{5}$ values near zero, which strengthen the above argument (Fig. 7). Additionally, Figure $8 \mathrm{~d}$ shows a large positive slope or strong leaching trend of mobile elements (e.g. $\mathrm{MgO}$, $\mathrm{CaO}, \mathrm{Na}_{2} \mathrm{O}, \mathrm{K}_{2} \mathrm{O}$, and $\mathrm{P}_{2} \mathrm{O}_{5}$ ) and the $\tau$ values, as mentioned above, account for varying dilutions caused by a range of organic material and water. This indicates that mobile elements such as $\mathrm{MgO}, \mathrm{CaO}, \mathrm{Na}_{2} \mathrm{O}, \mathrm{K}_{2} \mathrm{O}$, and $\mathrm{P}_{2} \mathrm{O}_{5}$ leach more readily than $\mathrm{SiO}_{2}$. Additionally, the range of $\mathrm{HVO}$ soil $\mathrm{HI}$ and OI values mentioned above indicate that organic matter is dominated by vascular plant debris rather than algae, which is expected.

Nelson et al. (2013), among others, have found $\mathrm{SiO}_{2}$, in the form of quartz, in small abundances across the Hawaiian Islands of probable eolian origin. However, HVO 2018 soils samples do not contain quartz likely because eolian quartz has yet to accumulate on the young Kilauea surface.

\subsubsection{Controlling Variables Relationship with NTM}


As mentioned above, the NMDS analysis better accounts for variance (e.g. $92 \%$ total variance explained in NMDS vs. 63\% explained in PCA) in the HVO 2018 soil dataset and both axes were statistically significant, therefore, it is used to make inferences regarding which elements promote or inhibit NTM.

TOC, $\mathrm{pH}, \mathrm{P}_{2} \mathrm{O}_{5}$, mafic silicates (e.g. olivine and pyroxene), and $\mathrm{Pb}$ control the positive NMDS 1 axis or NTM presence grouping. $\mathrm{Zr}, \mathrm{Ga}, \mathrm{Nb}, \mathrm{Y}, \mathrm{TiO}_{2}, \mathrm{Rb}$, and $\mathrm{Sr}$ control the negative MDS 1 or NTM absence grouping (Discussed further below) (Fig. 6d). As mentioned above, Figure 9 shows that TOC, $\mathrm{SiO}_{2}, \mathrm{Fe}_{2} \mathrm{O}_{3}, \mathrm{Sc}, \mathrm{MnO}, \mathrm{P}_{2} \mathrm{O}_{5}, \mathrm{TiO}_{2}, \mathrm{~V}, \mathrm{Sm}, \mathrm{Zr}, \mathrm{Cr}, \mathrm{Ga}, \mathrm{pH}$, and $\mathrm{MgO}$ all have statistically significant separation based on the Kolmogorov-Smirnov test (i.e. the NTM presence data distribution and the NTM absence data distribution for $\mathrm{TOC}, \mathrm{SiO}_{2}$, etc., rejected the hypothesis that both sample sets are from the same population). Greater consideration is given to these variables considering the statistical significance.

Also, as noted above, the intercept and both variables (e.g. TOC and $\mathrm{P}_{2} \mathrm{O}_{5}$ ) that were used in the logistic regression model showed coefficients with confidence intervals that overlapped zero as much as 1.32 standard deviations (Table 4b). While recognizing the confidence interval overlap, the logistic model is presented as a starting point for further research and the uncertainty is recognized.

\subsubsection{Transition Metals}

Figure 6d, again, shows that $\mathrm{TiO}_{2}$ and trace metals such as $\mathrm{Ga}, \mathrm{Zr}, \mathrm{Ga}$, and $\mathrm{Sr}$ strongly control the NTM absence grouping. All transition and trace metals (e.g. Sc, $\mathrm{TiO}_{2}, \mathrm{~V}, \mathrm{Sm}, \mathrm{Zr}, \mathrm{Cr}$, and Ga) shown in Figure 9 have NTM absent distributions that are centered at higher element concentrations than NTM present distributions. Additionally, as mentioned above, Niederweis et 
al. (2015) found that many transition metals can be toxic to Mycobacteria. These evidences suggest that trace elements shown in Figure 9 are statistically significant and correlated with NTM absence. Other trace metals shown also could be correlated with NTM absence to a lesser degree as shown in Figure 6d. $\mathrm{MgO}$, although not a trace metal oxide, shows a similar toxicity pattern (Fig. 9).

$\mathrm{TiO}_{2}$ (among other transitional metal oxides), for example, has been studied in clay minerals for its antibacterial properties (De Lanoy et al., 2008). On the other hand, Fe, Mn, and other transition metals have been shown to be essential micronutrients for M. Tuberculosis and potentially for NTM as well (Niederweis et al., 2015). There may be a threshold value to explain this contradiction where high concentrations are toxic, but some is needed. Toxicity levels in NTM may have been reached due to the rapid oxidation and weathering of Fe and Mn that occurs in Hawaii generally. Although $\mathrm{Zn}$ and $\mathrm{Cu}$ can be toxic to Mycobacteria, Niederweis et al. (2015) found that these are also important micronutrients in moderation. Furthermore, Mycobacteria have been shown to develop metal intake limiting capabilities.

\subsubsection{TOC and Soil Acidity}

Acidic soils have previously been correlated with the presence of NTM (Brooks et al., 1984; Falkinham III, 2002; Lipner et al., 2017). However, pH was shown to be a poor predictor variable when included in the logistic regression. The poorly correlated $\mathrm{pH}$ in the model could be due to the extreme acidities found near Kilauea considering Figure $6 \mathrm{~d}$ showed $\mathrm{pH}$ as a variable that strongly controlled the MDS 1 axis (i.e. higher $\mathrm{pH}$ has a higher NTM presence likelihood). Considering that the HVO dataset contains an average soil $\mathrm{pH}$ of 5 and Brooks et al. (1984), as another example of NTM correlations with acidity, had an average soil $\mathrm{pH}$ of 5.5, the difference and range of data could have affected this study's regression. Additionally, Brooks et al. (1984) 
found only a weak correlation with TOC, whereas TOC is the strongest correlated variable to NTM in this study (Fig. 9). Their study was in the Southeastern US and the authors were only interested in Mycobacterium avium, M. intracellular, and M. scrofuiaceum whereas this study evaluates 10 's of NTM species. To recap, other studies have found that lower $\mathrm{pH}$ is preferable for NTM with data ranges from slightly acidic to slightly basic and this study shows that higher $\mathrm{pH}$ is preferable with an acidic range of data. These results suggest that the range of $\mathrm{pH}$ that NTM prefer is between 4.5 and 6.5 .

This preferred $\mathrm{pH}$ range is likely due to nutrient availability. At basic $\mathrm{pH}$ conditions, there are fewer hydrogen ions, and metals such as $\mathrm{Cu}, \mathrm{Mn}, \mathrm{Fe}$, and $\mathrm{Zn}$ sorb to minerals and organic matter and thus are not bioavailable (McCauley et al., 2017). Given a lower $\mathrm{pH}$, the high concentration of hydrogen ions will sorb to mineral surfaces and metal ions will be bioavailable. However, $\mathrm{pH}$ values less than 5.5 have been shown to mobilize $\mathrm{Mn}$ and $\mathrm{Al}$ to toxic levels (McCauley et al., 2017). Mobile cations such as $\mathrm{Ca}^{2+}, \mathrm{Mg}^{2+}, \mathrm{K}^{+}$, and $\mathrm{Na}^{+}$sorb poorly at high $\mathrm{pH}$ and Figure $7 \mathrm{~b}$ shows that even in young soils, these elements have already undergone a broad range of leaching. Thus, although soil $\mathrm{pH}$ is not a strong, direct predictor of NTM in this study, the soil $\mathrm{pH}$ is important to and may control other NTM predictors.

Vitousek and Chadwick (2013) concluded that $\mathrm{pH}$ is controlled by major cations (e.g. lower abundances of $\mathrm{Ca}, \mathrm{Mg}, \mathrm{Na}$, and $\mathrm{K}$ drive lower $\mathrm{pH}$ ). There are high abundances of major cations near Kilauea suggesting a higher soil $\mathrm{pH}$, however, the $\mathrm{pH}$ is low. As mentioned above, $\mathrm{SO}_{2}$ emissions and acid rain at Kilauea are thought to cause soil acidity, which evidently override the major cations. Falkinham (2013) and Adjemian et al. (2012) also showed that humic and fulvic acids in the soil could potentially cause low soil $\mathrm{pH}$ and denote the presence and relative 
abundance of organic material, which shows a strong positive correlation in the regression model in the form of TOC.

\subsubsection{TOC and Soil Maturity}

The $\mathrm{SiO}_{2}$ distribution in Figure 9 shows a fairly clear separation between NTM presence vs. NTM absence with a Kolmogorov-Smirnov $p$-value of 0.001 . The NTM absence is generally associated with higher $\mathrm{SiO}_{2}$ concentrations and NTM presence is associated with lower $\mathrm{SiO}_{2}$ concentrations. Nelson et al. (2013) found that increased $\mathrm{SiO}_{2}$ leaching correlated with weathered soils. This study shows a negative correlation with an $R^{2}$ value of -0.94 between TOC and $\mathrm{SiO}_{2}$ confirming their findings and the idea that TOC increases as soil profiles weather. With this information and the Kolmogorov-Smirnov statistic for $\mathrm{SiO}_{2}$ and $\mathrm{TOC}$ in mind, the maturity of the soil and associated organic material is believed to play a significant role in NTM presence. Figure $8 \mathrm{~b}$ suggests that there has not been significant leaching of $\mathrm{SiO}_{2}$. Although the $\tau$ values shown in Figure 7a also do not model much $\mathrm{SiO}_{2}$ leaching generally, $\mathrm{SiO}_{2}$ weight percentages range from $30 \%$ to $56 \%$ after LOI corrections (Fig. 8).

\subsubsection{Phosphorous}

The $\mathrm{P}_{2} \mathrm{O}_{5}$ distributions in Figure 9 show a minor outlier in the NTM presence dataset that may be affecting the logistic regression. However, the Kolmogorov-Smirnov $p$-value is less than 0.01 indicating that the NTM presence vs. NTM absence datasets are not from the same population. The modeled regression probability curve approaches 1 with increased $\mathrm{P}_{2} \mathrm{O}_{5}$ concentrations as might generally be assumed considering $\mathrm{P}$ is a known nutrient (Fig. 9). Walker and Syers (1976) showed that inorganic P could be leached out of the soil in as little as 20,000

years or sooner given the similar rainfall amounts from their study area in New Zealand. On the 
contrary, $\tau$ values for $\mathrm{P}_{2} \mathrm{O}_{5}$ show that all $\mathrm{HVO}$ soils have been enriched over time (Fig. $7 \mathrm{~b}$ ). Derry and Chadwick (2007) noted that mineral aerosol fluxes contribute a large portion of Hawaiian P, which can be a limiting nutrient in this environment. HVO samples generally had only a quarter weight percent $\mathrm{P}_{2} \mathrm{O}_{5}$. Consequently, abundant NTM in the HVO samples (e.g. 22 of 41 samples had NTM) and noting their oligotrophic nature, Kilauea and the surrounding area may be an optimal location to thrive.

Walker and Syers (1976) also noted that peak values of organic matter begin to decrease as $\mathrm{P}$ leaching overwhelmed inorganic P concentrations that weathered from minerals or if the weathered inorganic $\mathrm{P}$ converted to inaccessible forms. This seems to confirm the idea that $\mathrm{P}$ is a limiting nutrient and related to TOC. The $\mathrm{P}_{2} \mathrm{O}_{5}$ values show strictly inorganic P. Future investigations of organic P in soil could prove fruitful in relation to NTM correlations.

\subsubsection{Future Soil Sampling}

Considering TOC was a major factor in determining NTM presence, future soil sampling transects across weathering gradients could refine NTM predictability. Sampling multiple soil TOC transects on all major Hawaiian Islands would add variables (i.e. substrate and island variability) not evaluated in this study.

The goal of regression modeling was to predict future NTM across the Hawaiian Islands as a potential starting point or type for other climates and environments. The HVO locality is unique, however, with lower soil $\mathrm{pH}$ than most areas due to $\mathrm{SO}_{2}$ emissions and acid rain, very recent soil formation (i.e. $<600 \mathrm{ka}$ ), and an increased geothermal gradient in the subsurface.

\subsection{Groundwater Modeling}

4.4.1 Model Variability 
$\mathrm{Kh} / \mathrm{Kv}$ values suggested in the NAVFAC model are 20 for dike free flank basalt. However, previous pump test analyses have shown that $\mathrm{Kh} / \mathrm{Kv}$ ratio values of 200 fit dike free flank basalt anisotropy models in southern Oahu better than 20 (Souza and Voss, 1987; Mink and Lau, 1990). Table 5 shows that there was a $3,000 \mathrm{~m}^{3} /$ day and $7,000 \mathrm{~m}^{3} /$ day difference between the $2 \mathrm{Kh} / \mathrm{Kv}$ models for the coastal boundary flux and the drain flux, respectively. Although, the percent difference between this study's models and the NAVFAC model for the coastal boundary was minimal (e.g. $0.22 \%$ ). The path of the flow lines and the travel time taken change between the two $\mathrm{Kh} / \mathrm{Kv}$ models, but both wells from both models derive nearly $100 \%$ of water from the upgradient stream. Figure 12 shows those path lines for $\mathrm{Kh} / \mathrm{Kv}=20$. Although there is a minimal difference between the two $\mathrm{Kh} / \mathrm{Kv}$ models in general, the $\mathrm{Kh} / \mathrm{Kv}=20$ model is thought to be more accurate in this area because of the smaller difference between this study and the NAVFAC's coastal boundary flux.

\subsubsection{Groundwater Particle Transport}

The conductivity of the dike free basalt and particle tracking results suggest that water in the model region should flush through the system in approximately 3 years. However, as mentioned above, tritium results show that the age of the stream water ranges from 1965 to the present (Fig. 5). The age range of the water suggests that there is a deeper groundwater flow that could intersect the two wells.

Shade and Nichols (1996) and Hunt Jr. (1996) reported that there is high-level, impounded groundwater, that is potentially older, in the central portion of Oahu referenced as the Schofield plateau and to the east of the model area as the Ko'olau Range. The Schofield plateau is known to impound water up to 100 meters due to laterite conductivity barriers or baffles and dikes. 
Groundwater in compartmentalized dikes in the Ko'loau Range can impound water up to 600 meters. These high water levels could be the source of the older water.

The majority of water originates from the stream as shown by all models (e.g. particle tracking, both $\mathrm{Kh} / \mathrm{Kv}$ models, and both uncertainty models) for both wells (Fig. 11). Figure 11d shows that particles could originate from stream zones hundreds of meters long. The particles, however, originate at the water table versus the actual stream, which stream is $16 \mathrm{~m}$ to $30 \mathrm{~m}$ above the water table. Recent work has been performed near Honolulu to understand the groundwater response to stream discharge variability and there seems to be a rapid response (Rosa, 2017). Since there seems to be a rapid response, the following fracture flow hypothesis assumes that there is a saturated system between the stream and the water table. There is a possibility of longer travel times, however, due to percolation through the vadose zone given the stream is disconnected from the water table. Appendix C proposes travel times from stream to aquifer with various apertures and a $1 \mathrm{~m}$ fracture width. Given the water table is $16 \mathrm{~m}$ to $30 \mathrm{~m}$ below the stream at Waimea, a colloid could potentially travel between water table and aquifer in a few hours with a $1 \mathrm{~m}$ fracture width and $100 \mu \mathrm{m}$ aperture. Additionally, Brooks et al. (1984) noticed a weak correlation between NTM and high conductivity systems as is seen on Oahu, which further supports potential aquifer transport of NTM.

On the other hand, considering NTM's preference for attachment and the rare presence of NTM in groundwater, it seems unlikely that aquifer transport of NTM is a transmission route from the environment to household plumbing. Nelson et al. (In Press) showed that hematite and goethite (e.g. Fe oxy/hydroxides) have potential grain sizes $\sim 1 \mu \mathrm{m}$ in diameter in Oahu streams. The $1 \mu \mathrm{m}$ Fe oxy/hydroxide grain could then attach to the $5 \mu \mathrm{m}$ long NTM tube. Additionally, Smith and Salman (1966) found that hematite has a point of zero charge of 8.68 in aqueous 
solution and Cristiano et al. (2011) found that goethite has a point of zero charge of 7.5. Hematite and Goethite generally have positive surface charges considering Oahu streams from all 3 sampling events had an average $\mathrm{pH}$ of 7.22. The positive Fe oxy/hydroxide grains could adhere to the negative NTM surface, potentially satisfy NTM's preference for attachment, and allow for colloidal transport through the aquifer.

As mentioned above, the average time for a particle of water to intersect the well screen from the water table below the stream was 41 and 76 days for wells 3803-03 and 3803-01, respectively. However, hydraulic conductivity values chosen for this area were low suggesting that a particle of water from the water table beneath the stream could intersect the well screen much earlier than the proposed average times. When water moves through an aquifer, there is some dispersion associated with it (i.e. some water arrives to the end location faster or slower than the average linear groundwater velocity, which velocity is the value produced by the MODPATH particle tracking). These findings suggest that a colloid could move through the aquifer much quicker than the conservative travel times presented.

This study stands as a proposal of NTM aquifer transport. Wells 3803-01 and 3803-03 were not analyzed for NTM presence or water chemistry in this study. Future modeling of streams and nearby well sampling in this area and others across Oahu could reveal interesting results considering residential water is almost entirely pumped groundwater on Oahu (Hunt Jr., 2004).

Another area for future work involves stream order. The 5 stream samples with NTM presence had low stream orders (e.g. 1-3) and 2 NTM absent stream samples had high stream orders (e.g. 8-12). As mentioned above, the model conductance was $0.25 \mathrm{~m} / \mathrm{d}$ downstream of the upper Waimea discharge measuring site and $1.85 \mathrm{~m} / \mathrm{d}$ upstream of the upper Waimea stream measuring site in order to properly calibrate the model (Fig. 2a). Although the dataset size was 
not substantial, both the NTM present, low stream order samples as well as the extrapolation that Hawaiian streams have high conductance values upstream suggest that NTM are entering the aquifer at upstream localities. High order streams, on the other hand, would be NTM absent perhaps due to the majority of NTM entering the aquifer through stream losses or sorption to the lower order stream beds. Further work and a larger dataset are necessary to reject or fail to reject this hypothesis.

\subsubsection{Additional NTM Transport Pathways}

As mentioned in the introduction, NTM may infect humans through a variety of routes. A transportation pathway that is often thought to infect humans includes aerosolization from household plumbing water that interacts with NTM biofilms in showerheads and faucets. Honda et al. (2016) demonstrated this idea in a recent study by finding NTM presence in 59\% of showerheads and faucets evaluated. An area less studied is the transportation of NTM from the environment to household plumbing. If groundwater transport (i.e. the hypothesis evaluated in this study) proves unlikely, mineral aerosols are a promising alternate route (Tuffley and Holbeche, 1980). Additionally, it has been suggested that water distribution centers are the source of NTM (Torvinen et al., 2004).

\section{CONCLUSIONS}

NMDS and PCA analyses for the 2012 dataset revealed that there is not a substantial separation between the NTM present and NTM absent distributions. Poor PCA and NMDS separation and Kolmogorov-Smirnov tests both suggest that mineralogy alone is not a significant NTM predictor. The PCA analysis for the 2018 stream dataset showed that TOC was not a major NTM predictor perhaps given the size of this dataset. Other variables such as transition metals 
appeared to correlate with NTM presence in stream water and major cations and anions seemed to correlate with NTM absence. Kolmogorov-Smirnov testing showed that $\mathrm{Mg}^{2+}$ and $\mathrm{SO}_{4}{ }^{2-}$ (i.e. potentially correlated with NTM absence) were the only statistically significant variables for the 2018 stream dataset between each variable's distributions of NTM presence vs. NTM absence. NMDS axes for the 2018 stream dataset were not statistically significant according to Kolmogorov-Smirnov testing between NTM presence vs. NTM absence distributions for each axis. Additional bacterial data and statistical reevaluation will be necessary to reject or fail to reject these findings.

The NMDS analysis for the 2018 HVO soil sample set showed that TOC, $\mathrm{pH}, \mathrm{P}_{2} \mathrm{O}_{5}$, mafic silicate minerals, and $\mathrm{Pb}$ seem to control the NTM presence grouping. Transition metals and oxides such as $\mathrm{TiO}_{2}, \mathrm{Zr}$, and $\mathrm{Nb}$ seem to control the absence grouping perhaps due to toxicity. Kolmogorov-Smirnov testing showed that TOC, $\mathrm{SiO}_{2}, \mathrm{Fe}_{2} \mathrm{O}_{3}, \mathrm{Sc}, \mathrm{MnO}, \mathrm{P}_{2} \mathrm{O}_{5}, \mathrm{TiO}_{2}, \mathrm{~V}$, $\mathrm{Sm}, \mathrm{Zr}, \mathrm{Cr}, \mathrm{Ga}, \mathrm{pH}$, and $\mathrm{MgO}$ were statistically significant variables for the HVO dataset between each variable's distributions of NTM presence vs. NTM absence. Logistic regression modeling coupled with Kolmogorov-Smirnov testing supported that TOC and $\mathrm{P}_{2} \mathrm{O}_{5}$ could be used to explain the probability of NTM presence in soils similar to that found near Kilauea. Immobile oxides such as $\mathrm{Fe}_{2} \mathrm{O}_{3}$ and $\mathrm{Al}_{2} \mathrm{O}_{3}$ showed minimal leaching for the $\mathrm{HVO}$ samples as expected. However, mobile oxides such as $\mathrm{MgO}, \mathrm{CaO}, \mathrm{Na}_{2} \mathrm{O}, \mathrm{K}_{2} \mathrm{O}$, and $\mathrm{P}_{2} \mathrm{O}_{5}$ presented a large leaching trend with one outlier. $\mathrm{MgO}$, as one of the only mobile and statistically significant $\mathrm{HVO}$ variables, could be correlated with NTM absence, as well as other statistically significant trace metals, based on its inverse relationship with NTM presence.

The groundwater model implies that stream water could reach wells 3803-01 and 380303 in an average of 76 and 41 days, respectively. The first particles could arrive at the well, 
however, in 47 and 34 days for wells 3803-01 and 3803-03, respectively, ignoring dispersive effects. The calibrated model for the Waimea valley area was optimized when a $\mathrm{Kh} / \mathrm{Kv}$ value of 20 was implemented. Tritium, isotopic ages suggest that there is a deeper groundwater flow potentially originating from older, impounded Ko'olau or Schofield groundwater systems. Water chemistry modeling from the August, 2018 stream dataset suggested that Fe oxy/hydroxides (e.g. hematite and goethite) are oversaturated in the water. These minerals are shown to have grain sizes $<1 \mu \mathrm{m}$ in diameter, which could attach to NTM. This affixation could satisfy NTM's preference for attachment and cause the bacteria to travel through the aquifer as a colloid. Future modeling work with tighter parameters could show promising results. 


\section{REFERENCES}

Adjemian, J., Olivier, K.N., Seitz, A.E., Falkinham III, J.O., Holland, S.M., and Prevots, D.R., 2012, Spatial Clusters of Nontuberculous Mycobacterial Lung Disease in the United States: American Journal of Respiratory and Critical Care Medicine, v. 186, p. 553-558, doi:10.1164/rccm.2012050913OC.

Akaike, H., 1973, Information theory as an extension of the maximum likelihood principle, in Budapest, Akadémiai Kiadó, p. 267-281.

Brantley, S.L., and White, A., 2009, Approaches to Modeling Weathered Regolith: Reviews in Mineralogy and Geochemistry, v. 70, p. 435-484.

Brooks, R.W., Parker, B.C., Gruft, H., and Falkinham III, J.O., 1984, Epidemiology of Infection by Nontuberculous Mycobacteria: American Review of Respiratory Disease, v. 130, p. 630-633, doi:10.1164/arrd.1984.130.4.630.

Chadwick, O.A., Gavenda, R.T., Kelly, E.F., Ziegler, K., Olson, C.G., Elliott, W.C., and Hendricks, D.M., 2003, The impact of climate on the biogeochemical functioning of volcanic soils: Chemical Geology, v. 202, p. 195-223, doi:10.1016/j.chemgeo.2002.09.001.

Chorover, J., Amistadi, M.K., and Chadwick, O.A., 2004, Surface charge evolution of mineral-organic complexes during pedogenesis in Hawaiian basalt: Geochimica et Cosmochimica Acta, v. 68, p. 4859-4876, doi:10.1016/j.gca.2004.06.005.

Churchman, J., Whitton, J.S., Claridge, G., and Theng, B., 1984, Intercalation Method Using Formamide for Differentiating Halloysite from Kaolinite: Clays and Clay Minerals, v. 32, p. 241-248, doi:10.1346/CCMN.1984.0320401.

Cook, J.L., 2010, Nontuberculous mycobacteria: opportunistic environmental pathogens for predisposed hosts: British Medical Bulletin, v. 96, p. 45-59, doi:10.1093/bmb/ldq035.

Covert, T.C., Rodgers, M.R., Reyes, A.L., and Stelma, G.N., 1999, Occurrence of Nontuberculous Mycobacteria in Environmental Samples: Applied and Environmental Microbiology, v. 65, p. 24922496.

Craig, H., 1961, Isotopic Variation in Meteoric Waters: Science, v. 133, p. 1702-1703.

Cristiano, E., Hu, Y.-J., Siegfried, M., Kaplan, D., and Nitsche, H., 2011, A Comparison of Point of Zero Charge Measurment Methodology: Clays and Clay Minerals, v. 59, p. 107-115, doi:10.1346/CCMN.2011.0590201.

Dawson, D.J., 1971, Potential Pathogens Among Strains of Mycobacteria Isolated from House-Dusts: Medical Journal of Australia, v. 1, p. 679-681, doi:10.5694/j.1326-5377.1971.tb87787.x.

De Groote, M.A., Pace, N.R., Fulton, K., and Falkinham III, J.O., 2006, Relationships between Mycobacterium Isolates from Patients with Pulmonary Mycobacterial Infection and Potting Soils: Applied and Environmental Microbiology, v. 72, p. 7602-7606, doi:10.1128/AEM.00930-06.

De Lanoy, J.T., Schneider, A., and Krekeler, M.P.S., 2008, Investigation of a potential mineral-based disease control agent, in Houston, TX, Geological Society of America. 
Decker, R.W., Wright, T.L., and Stuaffer, P.H., 1987, U.S. Geological Survey Professional Paper: 1350, $1667 \mathrm{p}$.

Deenik, J., Miura, T., Yost, R., Dorman, N., Silva, J., and Connor, W., 2014, Hawaii Soil Atlas: Hawaii Soil Atlas, http://gis.ctahr.hawaii.edu/SoilAtlas\#overview (accessed March 2019).

Derry, L.A., and Chadwick, O.A., 2007, Contributions from Earth's atmosphere to soil: Elements, v. 3, p. 333-338, doi:10.2113/gselements.3.5.333.

Doell, R.R., and Dalrymple, G.B., 1973, Potassium-Argon Ages and Paleomagnetism of the Waianae and Koolau Volcanic Series, Oahu, Hawaii: GSA Bulletin, v. 84, p. 1217-1242, doi:10.1130/00167606(1973)84<1217:PAAPOT>2.0.CO;2.

Eggleton, R.A., Foudoulis, C., and Varkevisser, D., 1987, Weathering of Basalt: Changes in Rock Chemistry and Mineralogy: Clays and Clay Minerals, v. 35, p. 161-169.

Elharar, Y., Roth, Z., Hermelin, I., Moon, A., Peretz, G., Shenkerman, Y., Vishkautzan, M., Khalaila, I., and Gur, E., 2014, Survival of mycobacteria depends on proteasome-mediated amino acid recycling under nutrient limitation: Embo, v. 33(16), p. 1802-1814, doi:10.15252/embj.201387076.

El-Kadi, A.I., and Moncur, J.E.T., 2005, The History of Groundwater Management and Research in Hawaii: Water Resources Research Center, University of Hawaii at Manoa, 25 p.

Embil, J., Warren, P., Yakrus, M., Stark, R., Corne, S., Forrest, D., and Hershfield, E., 1997, Pulmonary Illness Associated With Exposure to Mycobacterium-avium Complex in Hot Tub Water:

Hypersensitivity Pneumonitis or Infection?, http:/www.sciencedirect.com/science/article/pii/S0012369215468412?via\%3Dihub (accessed January 2018).

Escobar, I.C., and Randall, A.A., 2001, Assimilable organic carbon (AOC) and biodegradable dissolved organic carbon (BDOC):: complementary measurements: Water Research, v. 35, p. 4444-4454, doi:10.1016/S0043-1354(01)00173-7.

Falkinham III, J.O., 2013, Ecology of Nontuberculous Mycobacteria-Where Do Human Infections Come from? Seminars in Respiratory and Critical Care Medicine, v. 34, p. 095-102, doi:10.1055/s0033-1333568.

Falkinham III, J.O., 2011, Nontuberculous Mycobacteria from Household Plumbing of Patients with Nontuberculous Mycobacteria Disease: Emerging Infectious Diseases, v. 17, p. 419-424, doi:10.3201/eid1703.101510.

Falkinham III, J.O., 2002, Nontuberculous mycobacteria in the environment: Clinics in Chest Medicine, v. 23, p. 529-551.

Falkinham III, J.O., 2009, Surrounded By Mycobacteria: Nontuberculous Mycobacteria In The Human Environment: Journal of Applied Microbiology, v. 107, p. 356-367, doi:10.1111/j.13652672.2009.04161.x.

Falkinham III, J.O., Iseman, M.D., de Haas, P., and van Soolingen, D., 2008, Mycobacterium avium in a shower linked to pulmonary disease: Journal of Water and Health, v. 6, p. 209-213, doi:10.2166/wh.2008.032. 
Falkinham III, J.O., Norton, C.D., and LeChevallier, M.W., 2001, Factors Influencing Numbers of Mycobacterium avium, Mycobacterium intracellulare, and Other Mycobacteria in Drinking Water Distribution Systems: Applied and Environmental Microbiology, v. 67, p. 1225-1231, doi:10.1128/AEM.67.3.1225-1231.2001.

Falkinham III, J.O., Parker, B.C., and Gruft, H., 1980, Epidemiology of Infection by Nontuberculous Mycobacteria: American Review of Respiratory Disease, v. 121, p. 931-937, doi:10.1164/arrd.1980.121.6.931.

Feazel, L.M., Baumgartner, L.K., Peterson, K.L., Frank, D.N., Harris, J.K., and Pace, N.R., 2009, Opportunistic pathogens enriched in showerhead biofilms: Proceedings of the National Academy of Sciences, v. 106, p. 16393-16399, doi:10.1073/pnas.0908446106.

Flanagan, F.J., 1976, Descriptions and analyses of eight new USGS rock standards: Washington : U.S. Govt. Print. Off Geological Survey Professional Paper 840, 192 p.

Frazier, A.G., Giambelluca, T.W., Diaz, H.F., and Needham, H.L., 2016, Comparison of geostatistical approaches to spatially interpolate month-year rainfall for the Hawaiian Islands: International Journal of Climatology, v. 36, p. 1459-1470, doi:10.1002/joc.4437.

Gingerich, S.B., and Oki, D.S., 2011, Hydrogeology of the Hawaiian islands, in Cuatro décadas de investigación y formación en aguas subterráneas: libro homenaje al profesor Emilio Custodio, Zaragoza, Spain, Asocación Internacional de Hidrogeólogos, Grupo Español, p. 119-134.

Gramlich, J.W., Lewis, V.A., and Naughton, J.J., 1971, Potassium-Argon Dating of Holocene Basaslts of the Honolulu Volcanic Series: Geological Society of America Bulletin, v. 82, p. 1399-1404.

Hampton, M.A., Blay, C.T., and Murray, C.J., 2004, Carbonate Sediment Deposits on the Reef Front Around Oahu, Hawaii: Marine Georesources \& Geotechnology, v. 22, p. 65-102, doi:10.1080/10641190490473407.

Honda, J.R. et al., 2016, Environmental Nontuberculous Mycobacteria in the Hawaiian Islands: PLOS Neglected Tropical Diseases, v. 10, p. 17, doi:10.1371/journal.pntd.0005068.

Hudson, S.M., Hillam, S.A., Barker, J., Nelson, S.T., and Rey, K.A., 2019, Pyrolysis of Modern Wetland Sediment: Extracting Climate Records From Fens in the Uinta Mountains and Fish Lake Plateau, Utah, USA: Boreas, p. 15, doi:10.1111/bor.12378.

Hunt Jr., C.D., 1996, Geohydrology of the Island of Oahu, Hawaii: U.S. Geological Survey Professional Paper USGS Numbered Series 1412-B, 63 p.

Hunt Jr., C.D., 2004, Ground-Water Quality and its Relation to Land Use on Oahu, Hawaii, 2000-01: U.S. Geological Survey Water-Resources Investigations Report 03-4305, 76 p.

Kahana, L.M., Kay, J.M., Yakrus, M.A., and Waserman, S., 1997, Mycobacterium avium complex infection in an immunocompetent young adult related to hot tub exposure: Chest, v. 111, p. 242-245.

King, H.C., Khera-Butler, T., James, P., Oakley, B.B., Erenso, G., Aseffa, A., Knight, R., Wellington, E.M., and Courtenay, O., 2017, Environmental Reservoirs of Pathogenic Mycobacteria Across the Ethiopian Biogeographical Landscape.: PLOS ONE, v. 12(3), p. 15.

Lanphere, M.A., and Dalrymple, G.B., 1980, Age and Strontium Isotopic Composition of the Honolulu Volcanic Series, Oahu, Hawaii: American Journal of Science, v. 280-A, p. 736-751. 
Lau, L.S., and Mink, J.F., 1995, Groundwater modeling in Hawaii; a historical perspective: United States, Lewis Publishers : Boca Raton, FL, United States, 253 p.

Lau, L.S., and Mink, J.F., 2006, Hydrology of the Hawaiian Islands: University of Hawai'i Press.

Lautze, N., and Thomas, D., 2012, Hawai'i Groundwater and Geothermal Resources Center: Hawai'i State Water Wells, https:/www.higp.hawaii.edu/hggrc/projects/hawaii-state-waterwells/.

Lipner, E.M., Knox, D., French, J., Rudman, J., Strong, M., and Crooks, J.L., 2017, A Geospatial Epidemiologic Analysis of Nontuberculous Mycobacterial Infection: An Ecological Study in Colorado: Annals of the American Thoracic Society, v. 14, p. 1523-1532, doi:10.1513/AnnalsATS.201701-081OC.

Lytle, D., Frietch, C., and Covert, T., 2004, Electrophoretic Mobility of Mycobacterium avium Complex Organisms: Applied and Environmental Microbiology, v. 70, p. 5667-5671, doi:10.1128/AEM.70.9.5667-5671.2004.

Mangione, E.J., Huitt, G., Lenaway, D., Beebe, J., Bailey, A., Figoski, M., Rau, M.P., Albrecht, K.D., and Yakrus, M.A., 2001, Nontuberculous mycobacterial disease following hot tub exposure.: Emerging Infectious Diseases, v. 7, p. 1039-1042.

Marras, T.K., Wallace, R.J., Koth, L.L., Stulbarg, M.S., Cowl, C.T., and Daley, C.L., 2005, Hypersensitivity Pneumonitis Reaction to Mycobacterium avium in Household Water: CHEST, v. 127, p. 664-671, doi:10.1378/chest.127.2.664.

McCauley, A., Jones, C., and Olson-Rutz, K., 2017, Soil pH and Organic Matter: Soil pH and Organic Matter, http://landresources.montana.edu/nm/documents/NM8.pdf.

McDougall, I., 1979, Age of Shield-Building Volcanism of Kauai and Linear Migration of Volcanism in the Hawaiian Island Chain: Earth and Planetary Science Letters, v. 46, p. 31-42, doi:10.1016/0012821X(79)90063-3.

Mink, J.F., and Lau, L.S., 1990, Aquifer identification and classification for Oahu: Groundwater protection strategy for Hawaii: Water Resources Research Center, University of Hawaii at Manoa Report 179, 36 p.

Mink, J.F., and Lau, L.S., 1980, Hawaiian Groundwater Geology and Hydrology, and Early Mathematical Models: Water Resources Research Center, University of Hawaii at Manoa Techical Memorandum $62,83 \mathrm{p}$.

Mirsaeidi, M., Farnia, P., Sadikot, R., Hsueh, P.-R., and Aliberti, S., 2015, Nontuberculous Mycobacteria: Epidemiologic, Mycobacteriologic, and Clinical Aspects: BioMed Research International, v. 2015, p. 2, doi:10.1155/2015/523697.

Mirsaeidi, M., Machado, R.F., Garcia, J.G.N., and Schraufnagel, D.E., 2014, Nontuberculous Mycobacterial Disease Mortality in the United States, 1999-2010: A Population-Based Comparative Study: PLOS ONE, v. 9, p. 9, doi:10.1371/journal.pone.0091879.

Moulin, G.C. du, Stottmeier, K.D., Pelletier, P.A., Tsang, A.Y., and Hedley-Whyte, J., 1988, Concentration of Mycobacterium avium by Hospital Hot Water Systems: JAMA, v. 260, p. 15991601, doi:10.1001/jama.1988.03410110107037. 
Mueller, B., 2015, Experimental Interactions Between Clay Minerals and Bacteria: A Review: Pedosphere, v. 25, p. 799-810, doi:10.1016/S1002-0160(15)30061-8.

Nachbar-Hapai, M., Siegel, B.Z., Russell, C., Siegel, S.M., Siy, M.-L., and Priestley, D., 1989, Acid Rain in the Kilauea Volcano Area (Hawaii): Archives of Environmental Contamination and Toxicology, v. 18, p. 65-73, doi:10.1007/BF01056191.

Nagelkerke, N.J.D., 1991, A Note on a General Definition of the Coefficient of Determination: Biometrika, v. 78, p. 691-692, doi:10.2307/2337038.

Nelson, S., Honda, J., Robinson, S., and Rey, K., In Press, The evaluation of suspended stream sediment as a link between the presence of NTM in home plumbing in Oahu, Hawaii, USA: Geochemical controls on human infection:

Nelson, S.T., Tingey, D.G., and Selck, B., 2013, The denudation of ocean islands by ground and surface waters: The effects of climate, soil thickness, and water contact times on Oahu, Hawaii: Geochimica et Cosmochimica Acta, v. 103, p. 276-294, doi:10.1016/j.gca.2012.09.046.

Niederweis, M., Wolschendorf, F., Mitra, A., and Neyrolles, O., 2015, Mycobacteria, Metals, and the Macrophage: Immunological reviews, v. 264, p. 249-263, doi:10.1111/imr.12265.

Nishiuchi, Y. et al., 2007, The Recovery of Mycobacterium avium-intracellulare Complex (MAC) from the Residential Bathrooms of Patients with Pulmonary MAC: Clinical Infectious Diseases, v. 45, p. 347-351, doi:10.1086/519383.

Norton, C.D., LeChevallier, M.W., and Falkinham III, J.O., 2004, Survival of Mycobacterium Avium in a Model Distribution System: Water Research, v. 38, p. 1457-1466, doi:10.1016/j.watres.2003.07.008.

Oki, D.S., 1998, Geohydrology of the Central Oahu, Hawaii, Ground-Water Flow System and Numerical Simulation of the Effects of Additional Pumping: Geological Survey (U.S.) Water-Resources Investigations Report USGS Numbered Series 97-4276, 142 p.

Parfitt, R.L., Childs, C.W., and Eden, D.N., 1988, Ferrihydrite and allophane in four Andepts from Hawaii and implications for their classification: Geoderma, v. 41, p. 223-241, doi:10.1016/00167061(88)90062-6.

Quane, S.L., Garcia, M.O., Guillou, H., and Hulsebosch, T.P., 2000, Magmatic history of the East Rift Zone of Kilauea Volcano, Hawaii based on drill core from SOH 1: Journal of Volcanology and Geothermal Research, v. 102, p. 319-338, doi:10.1016/S0377-0273(00)00194-3.

Rantz, S.E., 1982, Measurement and computation of streamflow: Volume 1, Measurement of stage and discharge: U.S. G.P.O., Water Supply Paper USGS Numbered Series 2175, 313 p.

Reyn, C.F. von, Waddell, R.D., Eaton, T., Arbeit, R.D., Maslow, J.N., Barber, T.W., Brindle, R.J., Gilks, C.F., Lumio, J., and Lähdevirta, J., 1993, Isolation of Mycobacterium avium complex from water in the United States, Finland, Zaire, and Kenya.: Journal of Clinical Microbiology, v. 31, p. 3227-3230.

Rosa, S.N., 2017, Measuring surface-water loss in Honouliuli Stream near the 'Ewa Shaft, O'ahu, Hawai'i: U. S. Geological Survey Scientific Investigations Report, 14 p.

Rotzoll, K., and El-Kadi, A.I., 2007, Numerical Ground-Water Flow Simulation For Red Hill Fuel Storage Facilities, NAVFAC Pacific, Oahu, Hawaii: University of Hawaii - Monoa Techincal Report, $86 \mathrm{p}$. 
Ryan, K.J., Ray, C.G., and Sherris, J.C., 2004, Sherris medical microbiology : an introduction to infectious diseases: New York, McGraw-Hill, 979 p.

Shade, P.J., and Nichols, W.D., 1996, Water Budget and the Effects of Land-Use Changes on GroundWater Recharge, Oahu, Hawaii: Geological Survey (U.S.) Professional Paper USGS Numbered Series $1412-\mathrm{C}, 48 \mathrm{p}$.

Sherrod, D.R., Sinton, J.M., Watkins, S.E., and Brunt, K.M., 2007, Geologic Map of the State of Hawaii:, https://pubs.usgs.gov/of/2007/1089/ (accessed April 2018).

Smith, G.W., and Salman, T., 1966, Zero-Point-of-Charge of Hematite and Zirconia: Canadian Metallurgical Quarterly, v. 5, p. 93-107, doi:10.1179/cmq.1966.5.2.93.

Souza, W.R., and Voss, C.I., 1987, Analysis of an anisotropic coastal aquifer system using variabledensity flow and solute transport simulation: Journal of Hydrology, v. 92, p. 17-41, doi:10.1016/0022-1694(87)90087-4.

Sowards, K., Nelson, S., McBride, J., Bickmore, B., Tingey, D., Rey, K., and Yaede, J., 2018, A Conceptual Model for the Early Weathering of Ocean Islands: A Synthesis of Geochemistry and Geophysics, Kohala Peninsula, Hawaii, USA: Geosphere, v. 14(3), p. 1324-1342.

Stearns, H.T., and Vaksvik, K.N., 1935, Geology and ground-water resources of the island of Oahu, Hawaii: Maui Publishing Company, Limited Bulletin Other Government Series 1, 536 p.

Takasaki, K.J., and Mink, J.F., 1985, Evaluation of Major Dike-Impounded Ground-Water Reservoirs, Island of Oahu: Geological Survey (U.S.) Water Supply Paper USGS Numbered Series 2217.

Taylor, R.H., Falkinham III, J.O., Norton, C.D., and LeChevallier, M.W., 2000, Chlorine, Chloramine, Chlorine Dioxide, and Ozone Susceptibility of Mycobacterium avium: Applied and Environmental Microbiology, v. 66, p. 1702-1705, doi:10.1128/AEM.66.4.1702-1705.2000.

Torvinen, E., Suomalainen, S., Lehtola, M.J., Miettinen, I.T., Zacheus, O., Paulin, L., Katila, M.-L., and Martikainen, P.J., 2004, Mycobacteria in Water and Loose Deposits of Drinking Water Distribution Systems in Finland: Applied and Environmental Microbiology, v. 70, p. 1973-1981, doi:10.1128/AEM.70.4.1973-1981.2004.

Tuffley, R.E., and Holbeche, J.D., 1980, Isolation of the Mycobacterium avium-M. intracellulare-M. scrofulaceum complex from tank water in Queensland, Australia.: Applied and Environmental Microbiology, v. 39, p. 48-53.

University of Hawaii at Manoa, 2012, Hawai'i State Water Wells | Hawai'i Groundwater \& Geothermal Resources Center: Hawai'i State Water Wells, https://www.higp.hawaii.edu/hggrc/projects/hawaiistate-waterwells/ (accessed April 2019).

Vaerewijck, M.J.M., Huys, G., Palomino, J.C., Swings, J., and Portaels, F., 2005, Mycobacteria in Drinking Water Distribution Systems: Ecology and Significance for Human Health: FEMS Microbiology Reviews, v. 29, p. 911-934, doi:10.1016/j.femsre.2005.02.001.

Verruijt, A., 1968, A Note on the Ghyben-Herzberg Formula: International Association of Scientific Hydrology. Bulletin, v. 13, p. 43-46, doi:10.1080/02626666809493624.

Vitousek, P.M., and Chadwick, O.A., 2013, Pedogenic Thresholds and Soil Process Domains in BasaltDerived Soils: Ecosystems, v. 16, p. 1379-1395, doi:10.1007/s10021-013-9690-z. 
Walker, T.W., and Syers, J.K., 1976, The fate of phosphorus during pedogenesis: Geoderma, v. 15, p. 119, doi:10.1016/0016-7061(76)90066-5.

Wallace, R.J., Brown, B.A., and Griffith, D.E., 1998, Nosocomial outbreaks/pseudo-outbreaks caused by nontuberculous mycobacteria: Annual Review of Microbiology, v. 52, p. 453-490, doi:10.1146/annurev.micro.52.1.453.

Whittier, R.B., Rotzoll, K., Dhal, S., El-Kadi, A.I., Ray, C., and Chang, D., 2010, Groundwater Source Assessment Program for the State of Hawaii, USA: Methodology and Example Application: Hydrogeology, v. 18, p. 711-723, doi:10.1007/s10040-009-0548-6.

Wolfe, E.W., and Morris, J., 1996, Sample data for the geologic map of the island of Hawaii: U.S. Geological Survey 2524-B, doi:10.3133/i2524B.

Yaede, J.R., McBride, J.H., Nelson, S.T., Park, C.B., Flores, J.A., Turnbull, S.J., Tingey, D.G., Jacobsen, R.T., Dong, C.D., and Gardner, N.L., 2015, A Geophysical Strategy for Measuring the Thickness of the Critical Zone Developed Over Basalt Lavas: Geosphere, v. 11, p. 514-532, doi:10.1130/GES01142.1. 


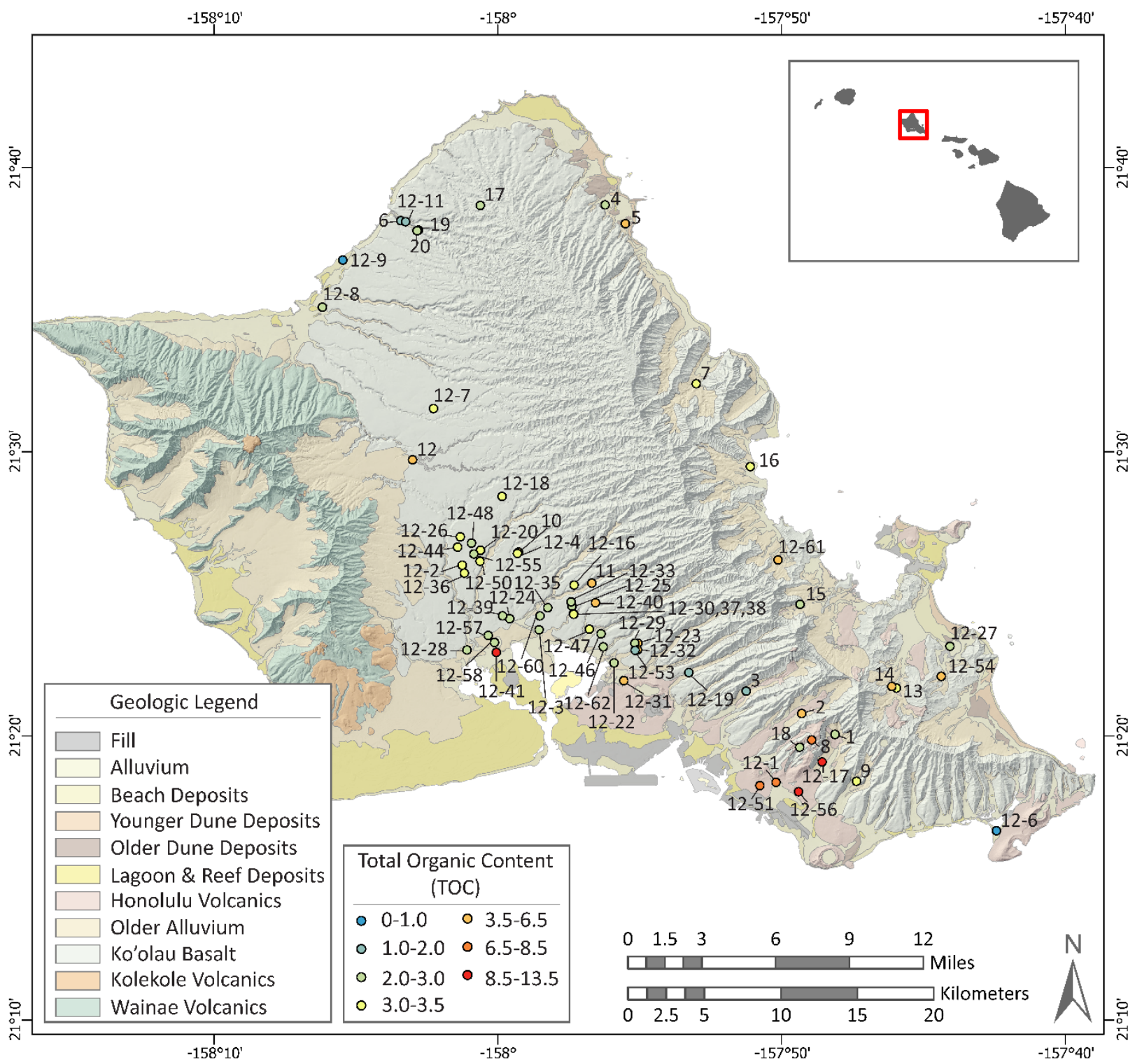

a.

Figure 1. Locations of 2012, 2018 stream, and 2018 HVO sampling sites. a.) Sampling locations of January, February, and August 2018 stream and soil sites and associated TOC values. Locations labeled with a "12-\#" are from the preliminary 2012 sampling. b.) Mineralogy pie charts and Stiff diagrams of soils and waters, respectively, from the Oahu 2018 dataset. c.) Index of all sampling sites across the Hawaiian Islands. c.) Sampling locations of HVO January 2018 soils and associated TOC values. 


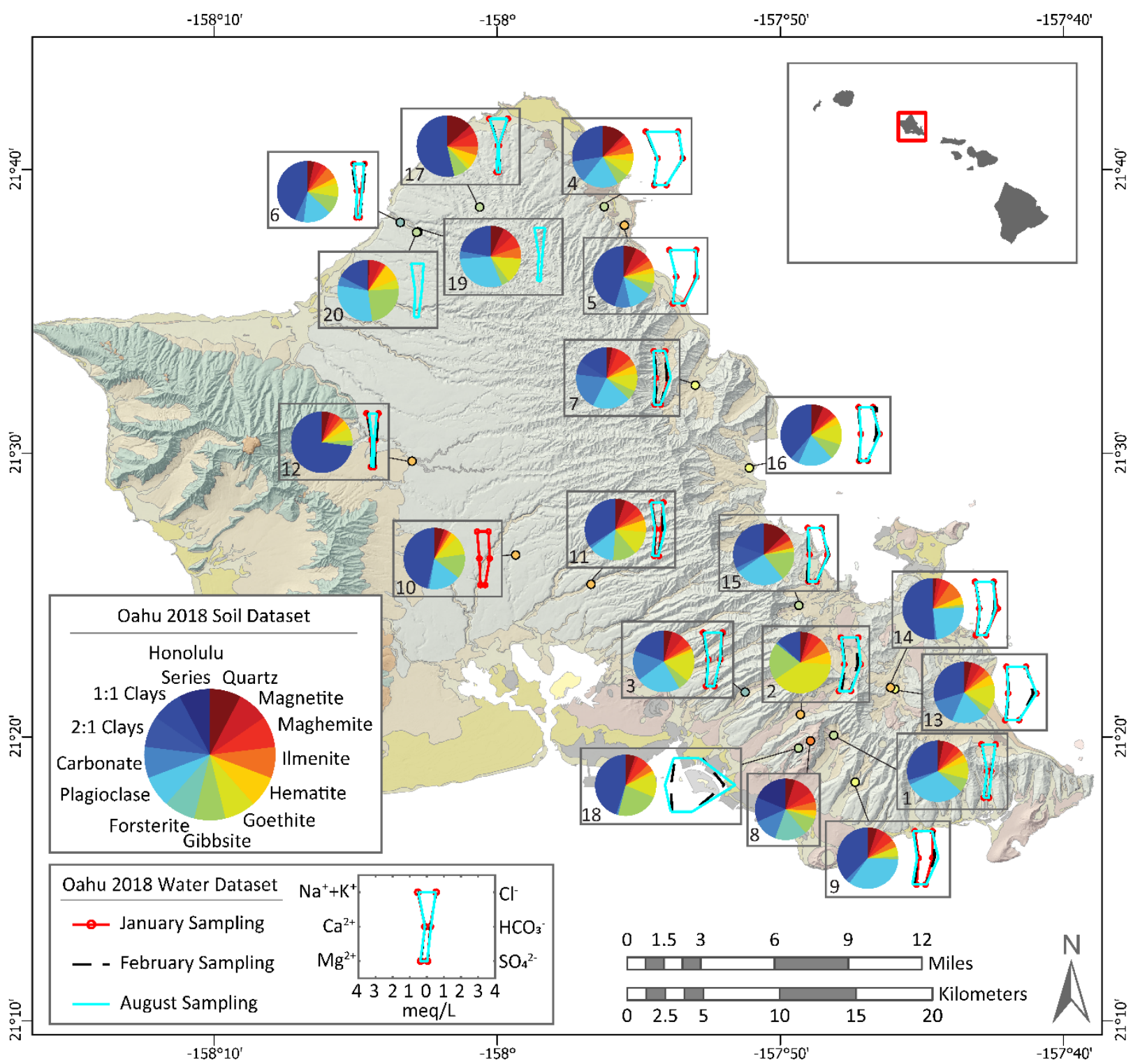

b. 

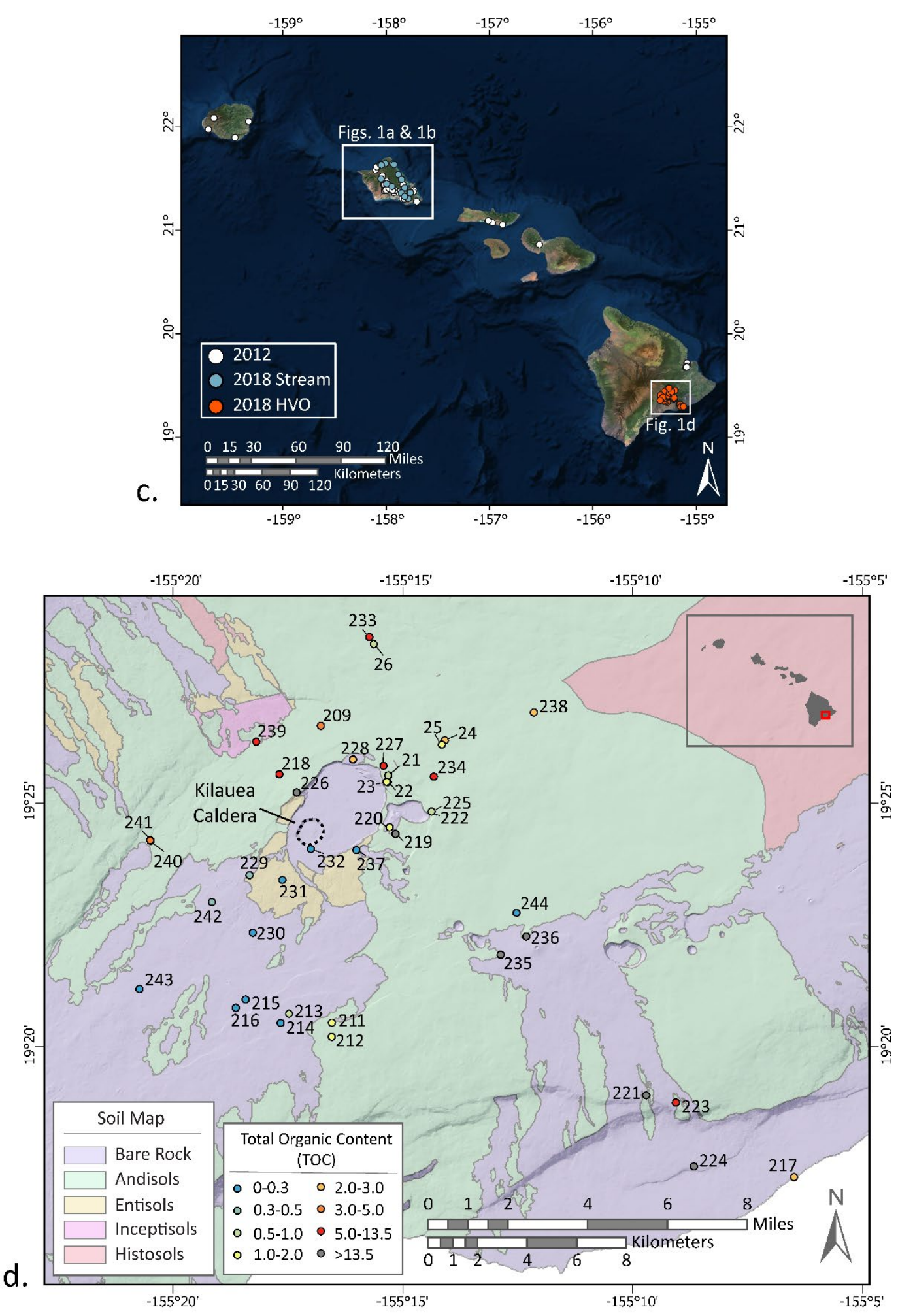


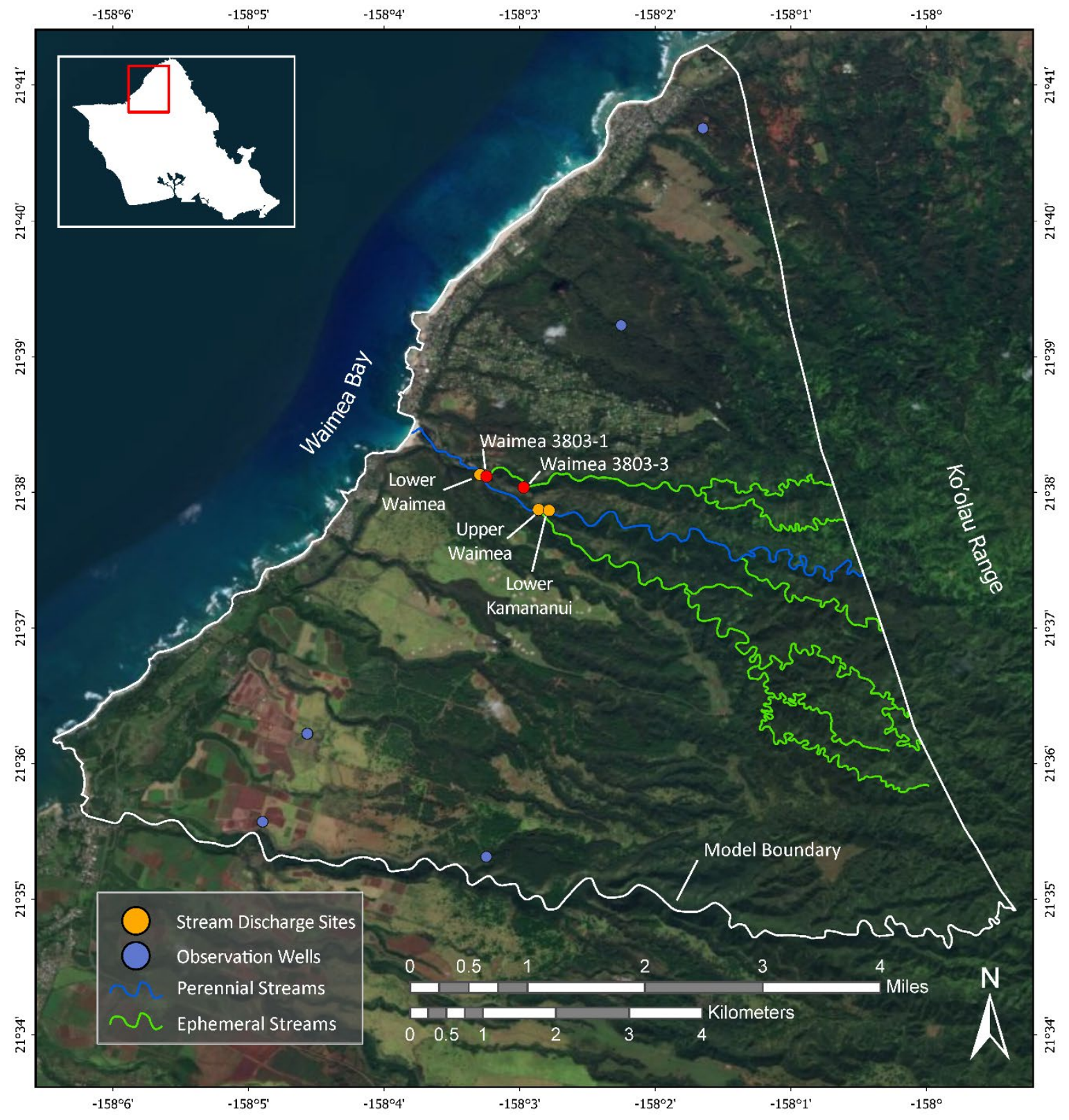

a.

Figure 2. a.) Groundwater modeling location in north-east Oahu. The red dots represent 2 pumping wells used in the groundwater model and the orange dots represent discharge measurements made in August, 2018. Model boundary locations are based on previous studies (Mink and Lau, 1990). b.) Aerial view of the model grid. 


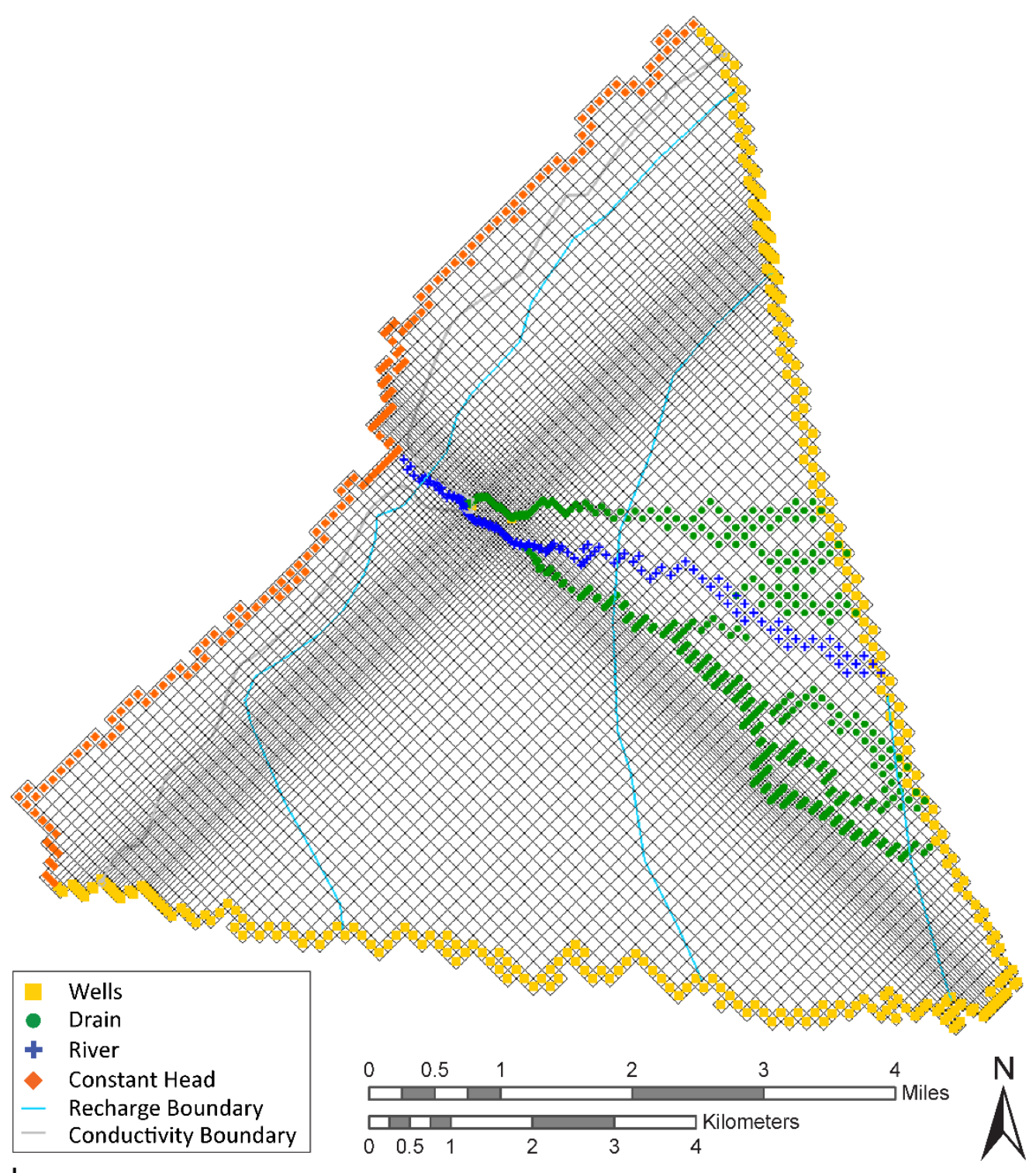

b. 

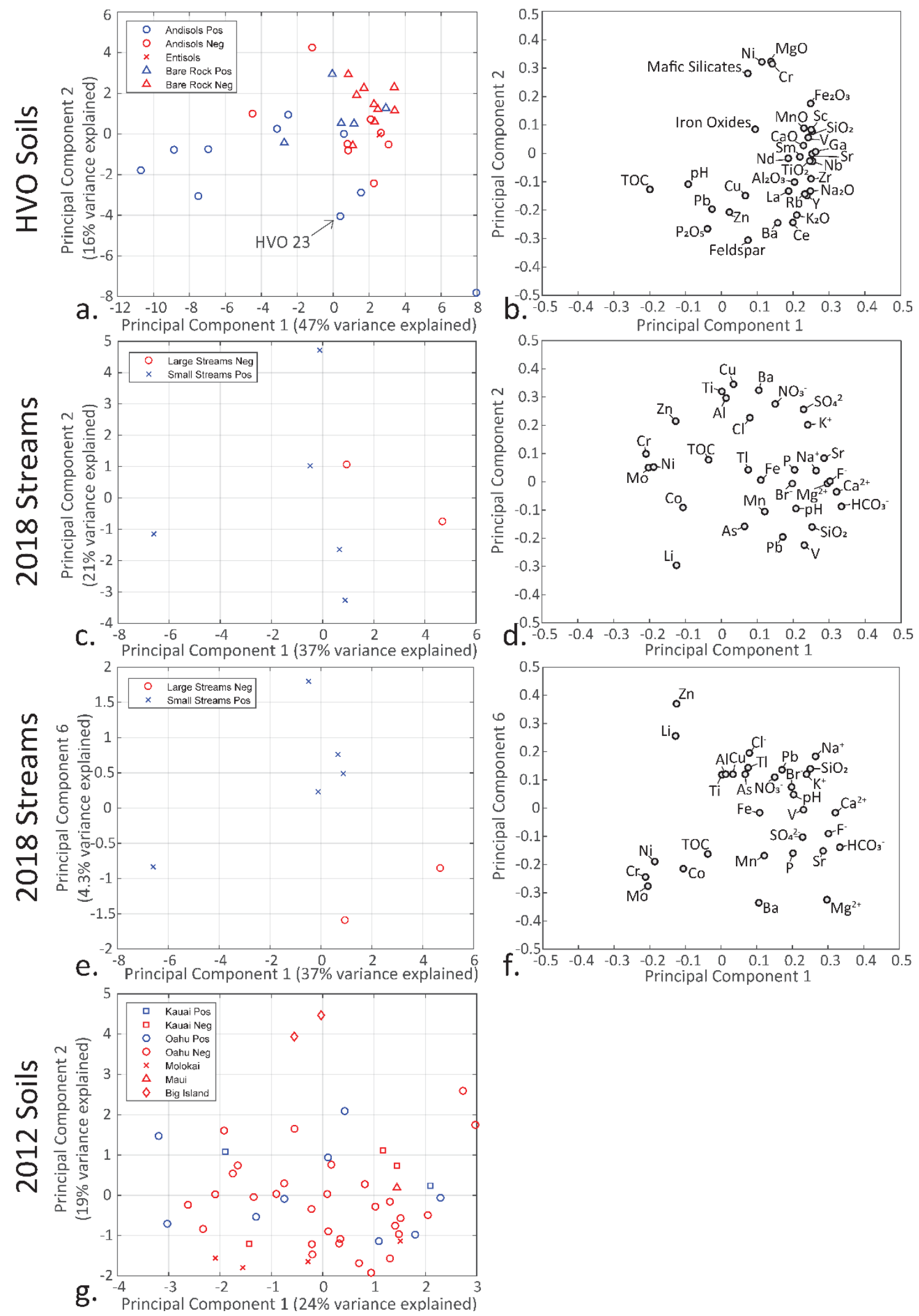

Figure 3. Principal Components Analysis (PCA) of HVO 2018 soil chemistry, Oahu 2018 soil chemistry, and 2012 soil mineralogy. Plots b, d, and f, show variable control of plots a, c, and e, respectively. 


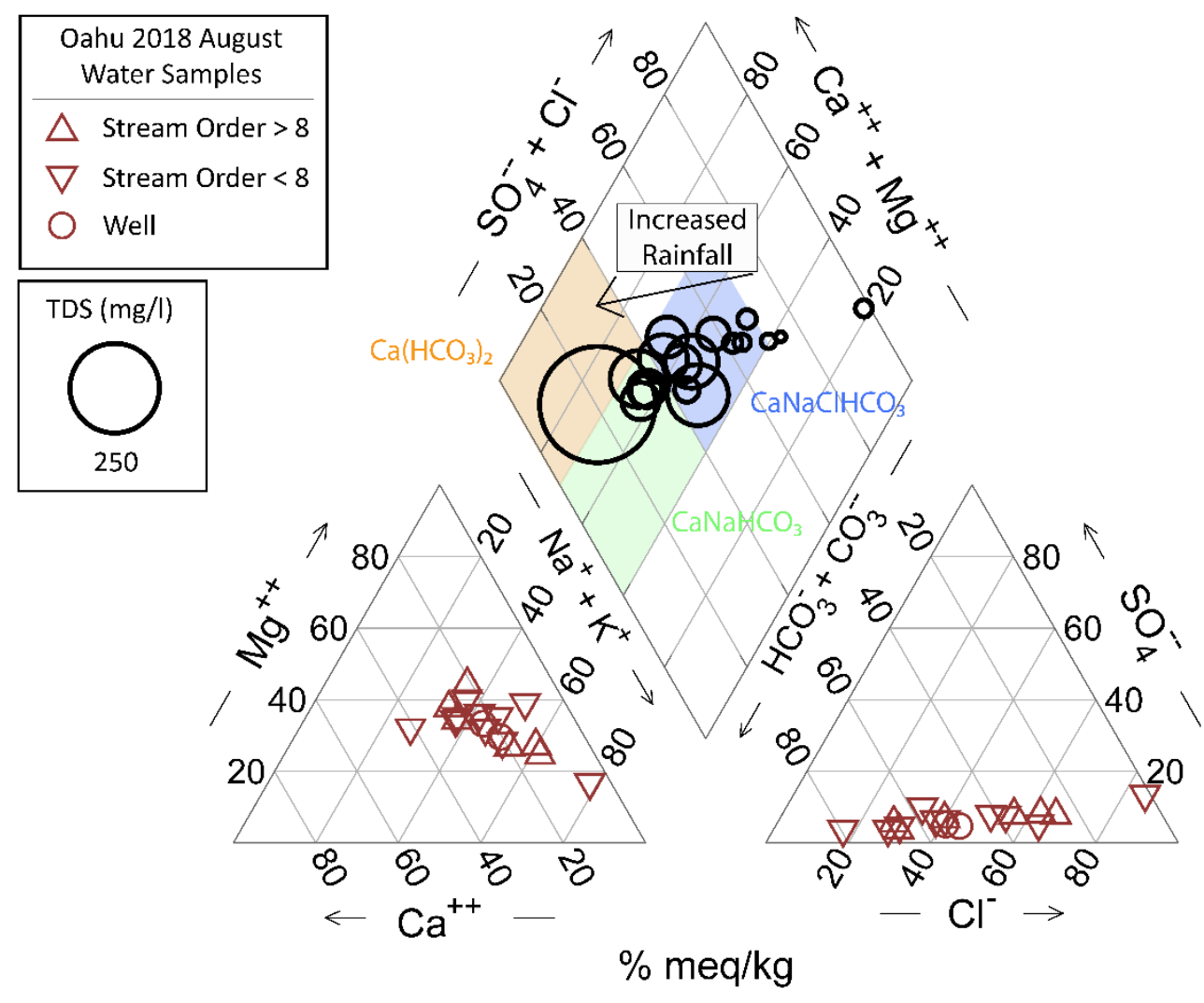

Figure 4. Piper diagram of Oahu 2018 August surface and groundwater samples. Samples plotted in the central diagram represent TDS concentrations. 


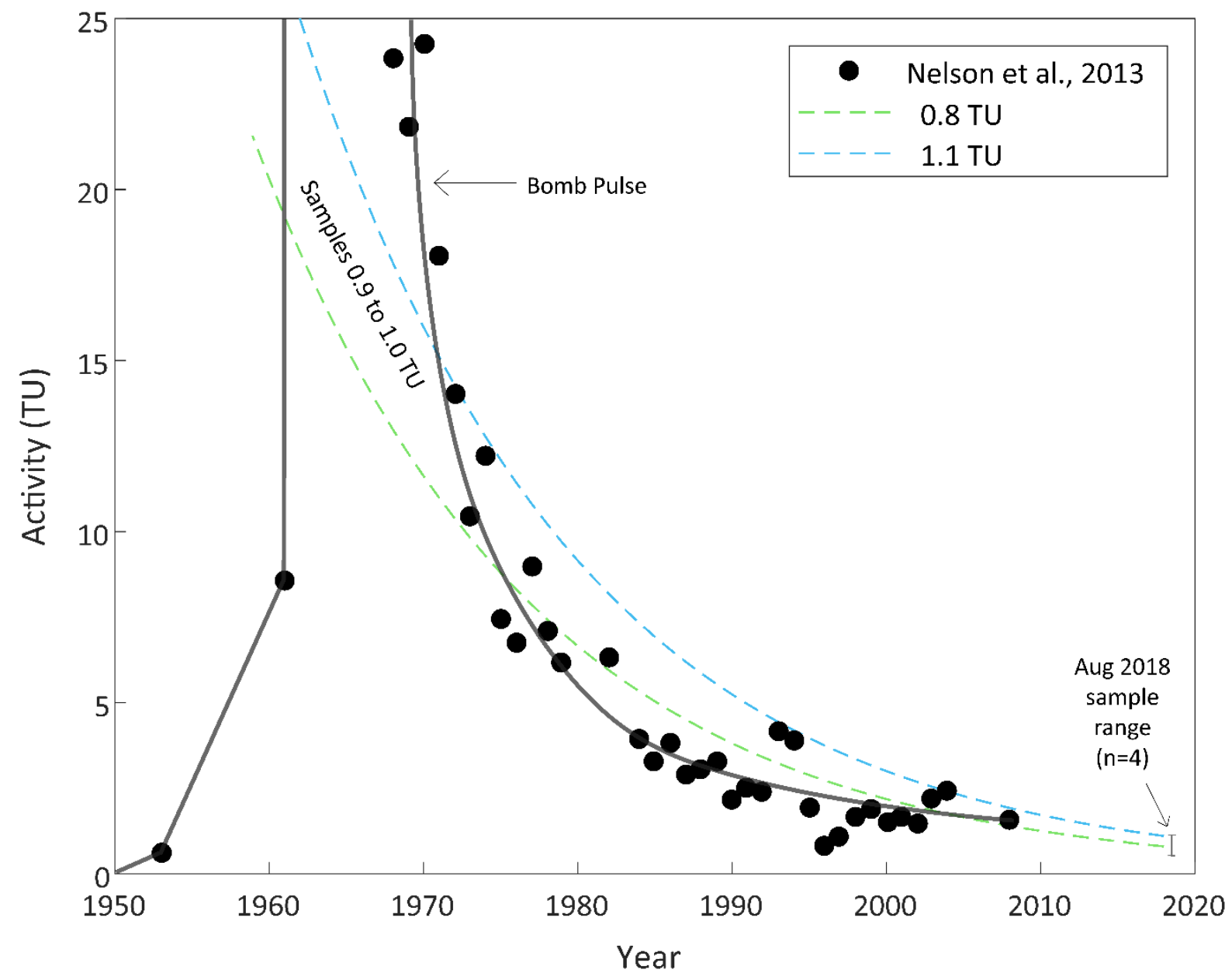

Figure 5. Tritium values through time. Black dots represent Pacific island precipitation tritium values. Blue, green, and red dotted lines represent the boundaries, with a $0.1 \mathrm{TU}$ error, of 4 samples measured for tritium in this study. Three of the four sites (e.g. lower Waimea, upper Waimea, and lower Kamananui) are shown on Figure 2a. The fourth site (e.g. 18-KRM-20) is shown on Figure 1a. 

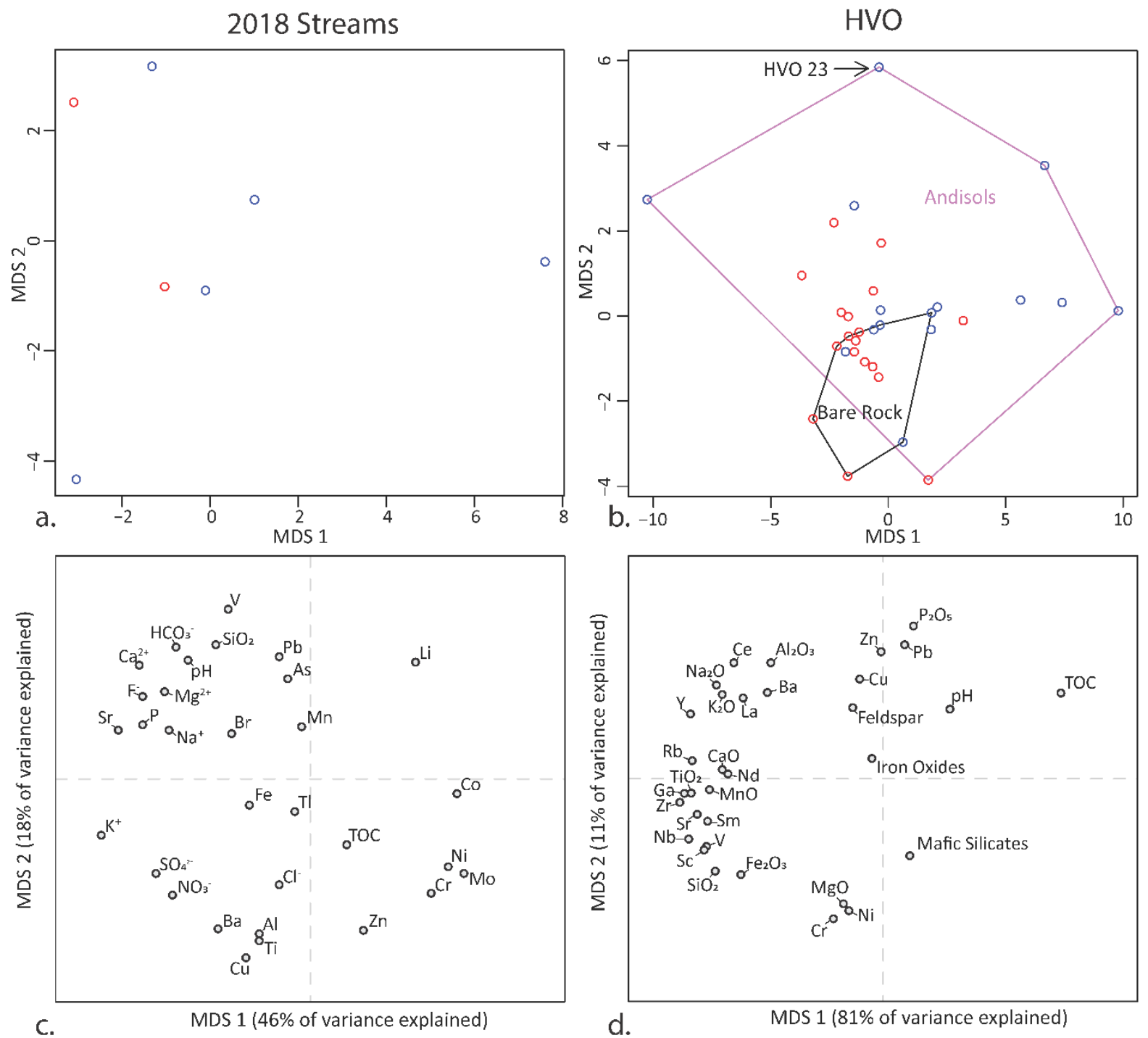

Figure 6. Non-metric multidimensional scaling (NMDS) of Oahu 2018 stream chemistry and HVO 2018 soil chemistry. Plots $\mathrm{c}$ and $\mathrm{d}$ show variable control for plots a and $\mathrm{b}$, respectively. 

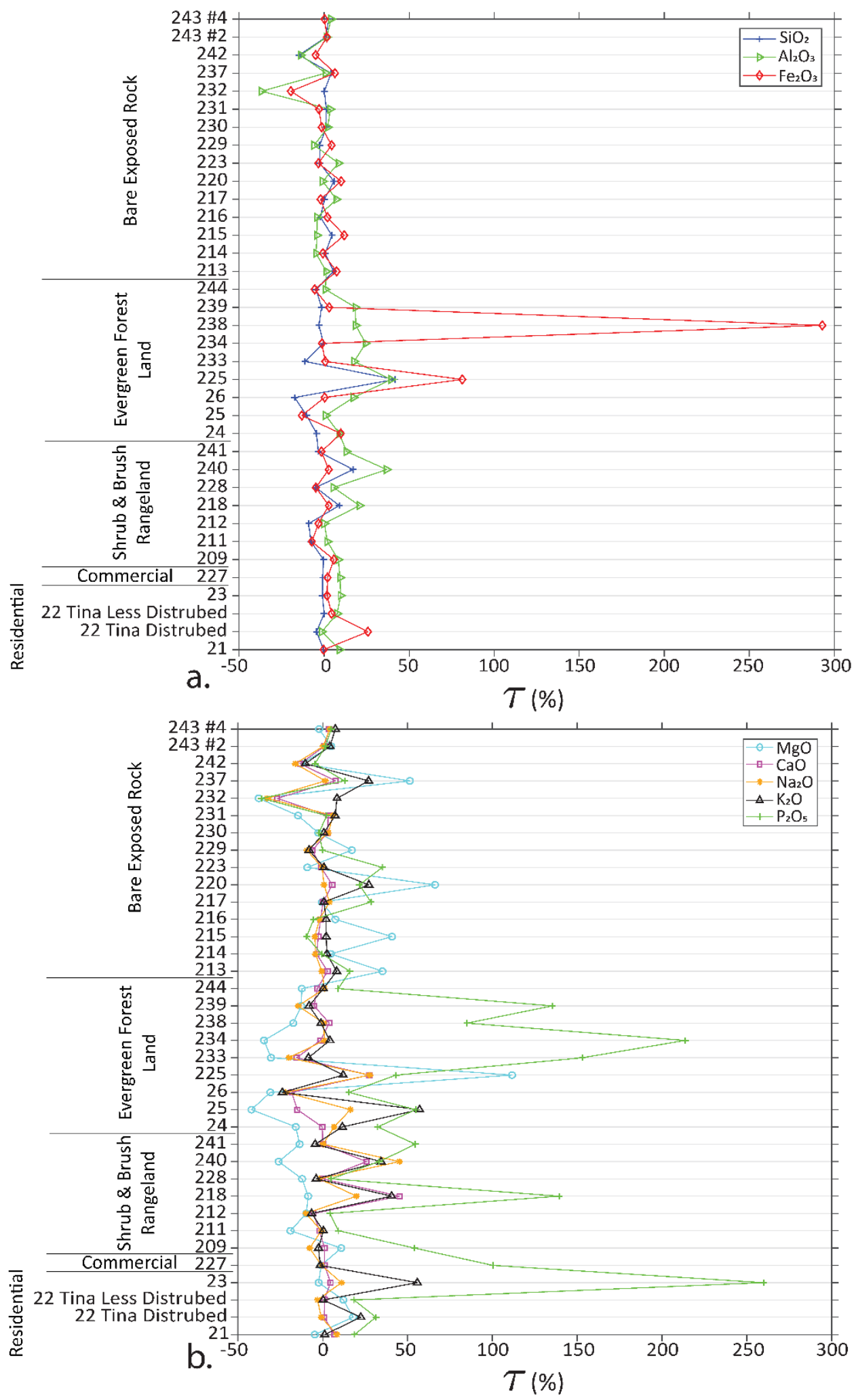

Figure 7. $\tau$ diagrams of elemental leaching and enrichment of HVO soils. $\tau$ values represent percent leaching or enrichment relative to immobile $\mathrm{TiO}_{2}$. a.) Immobile elements. b.) Mobile elements. 

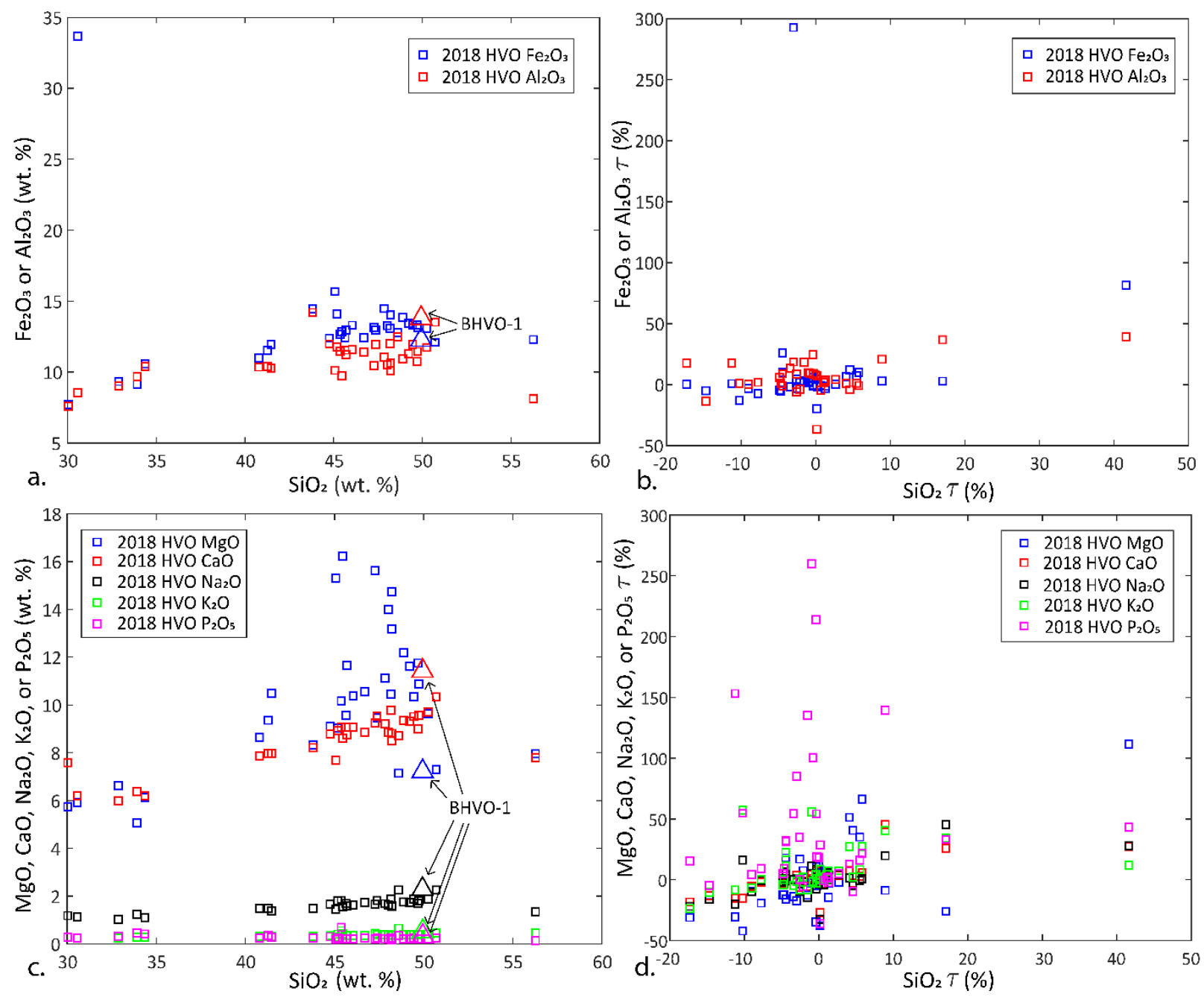

Figure 8. HVO soil immobile ( $\mathrm{a}$ and $\mathrm{b}$ ) and mobile (c and d) oxides plotted against $\mathrm{SiO}_{2}$. a. \& c.) Raw oxide values plotted against $\mathrm{SiO}_{2}$. b. and d.) Oxide $\tau$ values plotted against $\mathrm{SiO}_{2}$. 

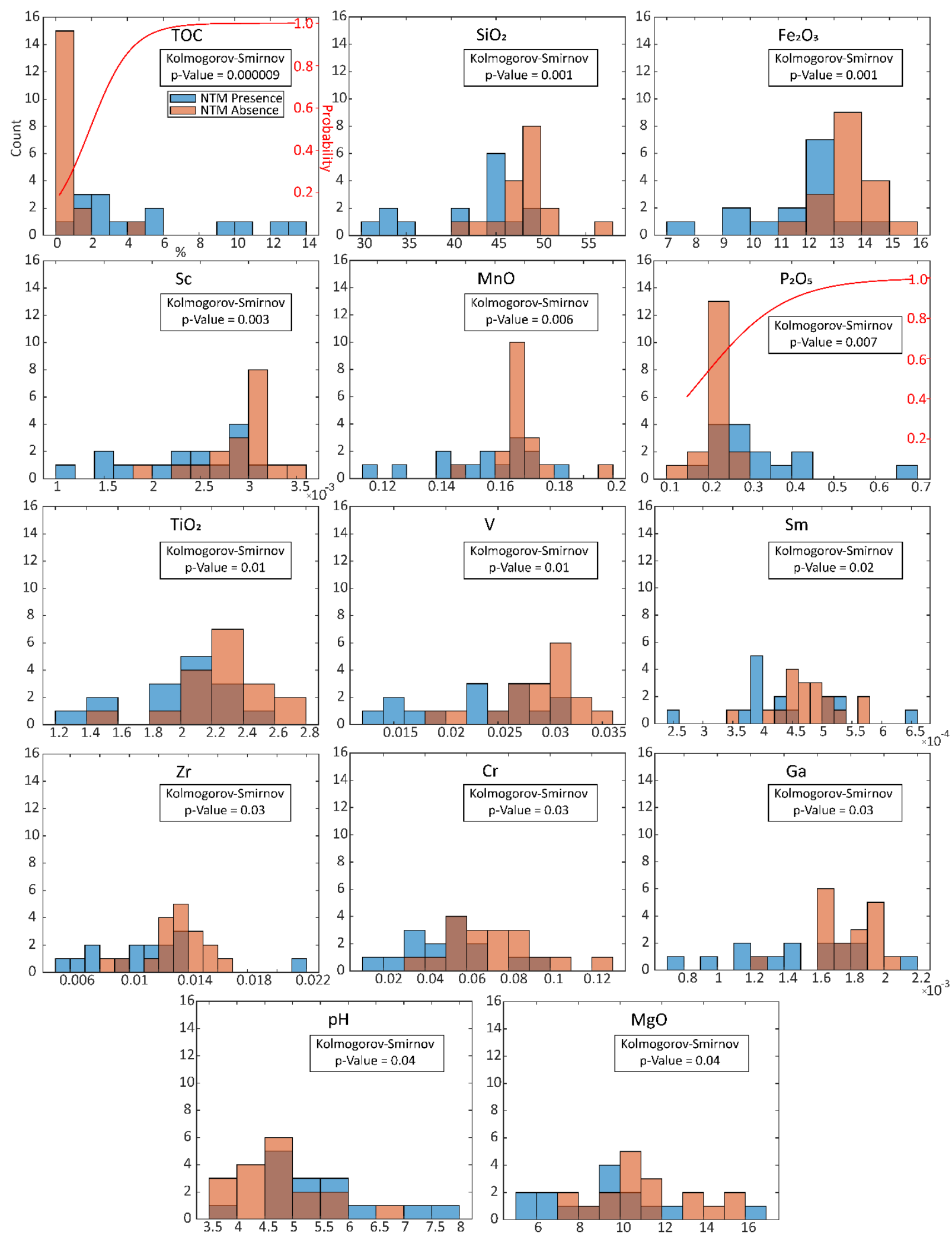

Figure 9. Histograms of NTM presence vs. absence and Kolmogorov-Smirnov tests statistics for HVO soils. Logistic modeling probability curves of TOC and $\mathrm{P}_{2} \mathrm{O}_{5}$ are shown within histogram windows. Each histogram shows the entire variable value range. 

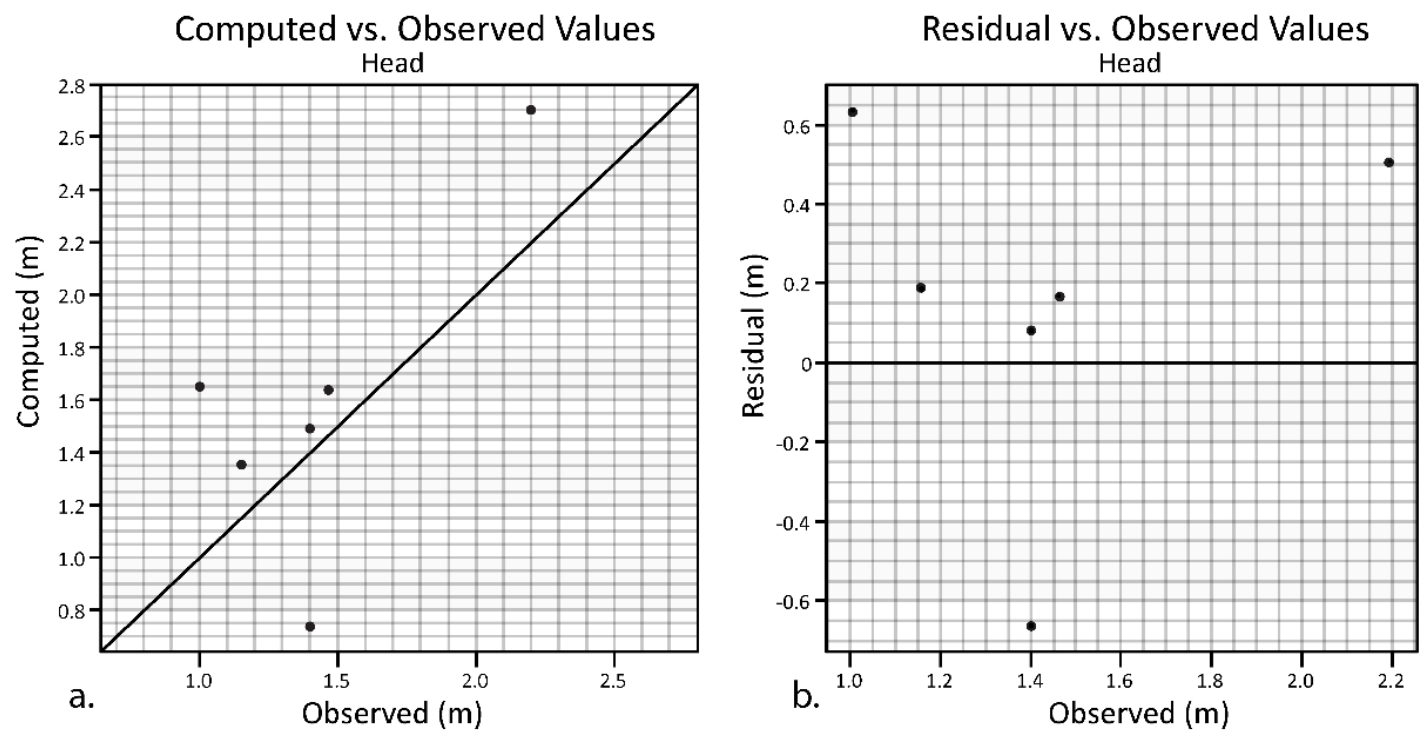

Figure 10. Hydraulic head calibration results from 6 observation wells (Fig. $2 \mathrm{a}$ ) used in the $\mathrm{Kh} / \mathrm{Kv}=20$ groundwater model. a.) Computed versus observed head values. b.) Residual values versus observed heads.

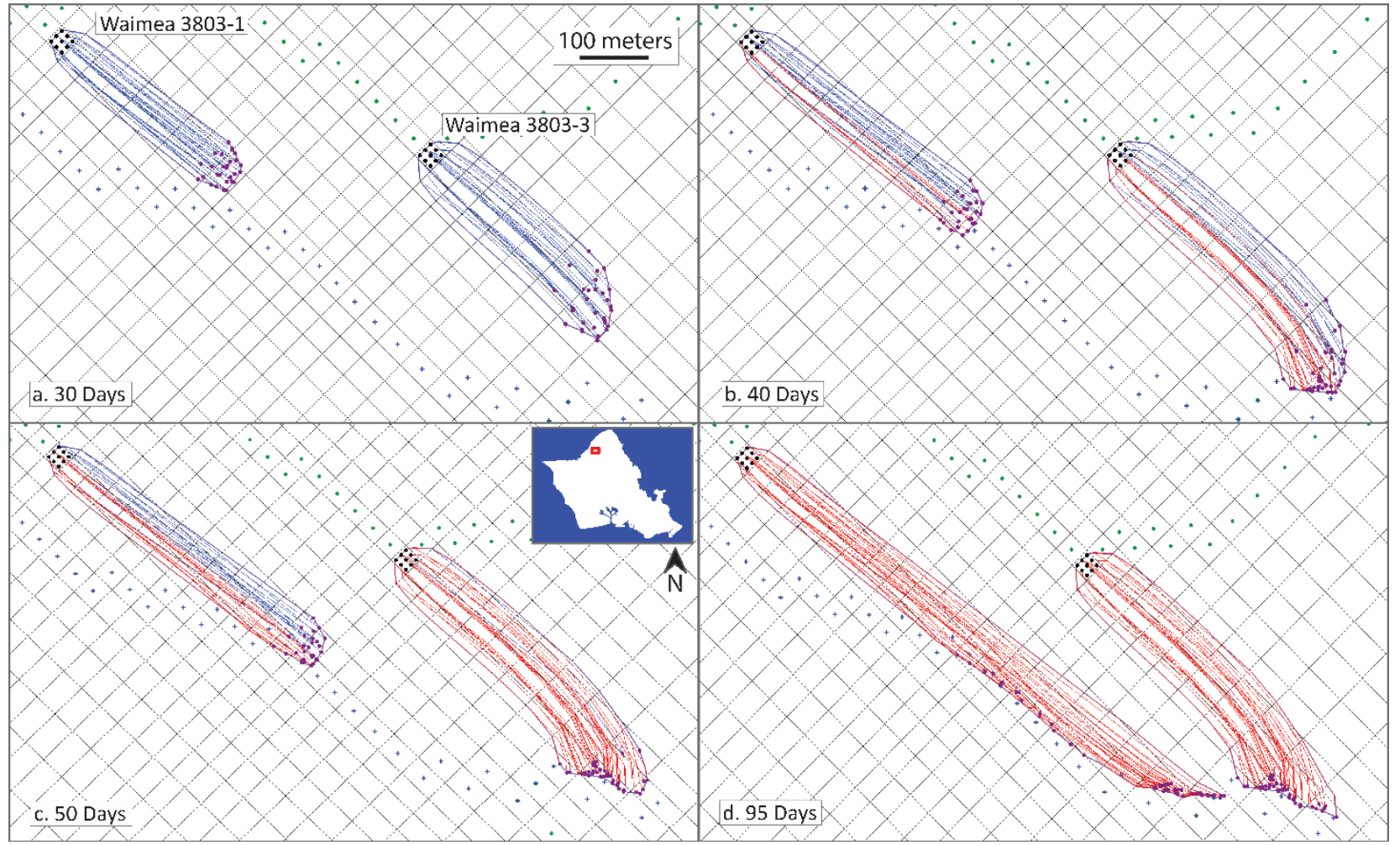

Figure 11. Particle tracking analysis and capture zones of wells 3803-01 and 3803-03. Green dots represent drain cells and blue plus signs represent Waimea stream. Red flow lines represent water captured from stream cells and blue flow lines represent water captured from other cells. In D flow lines end. $\mathrm{Kh} / \mathrm{Kv}$ is 20 . 


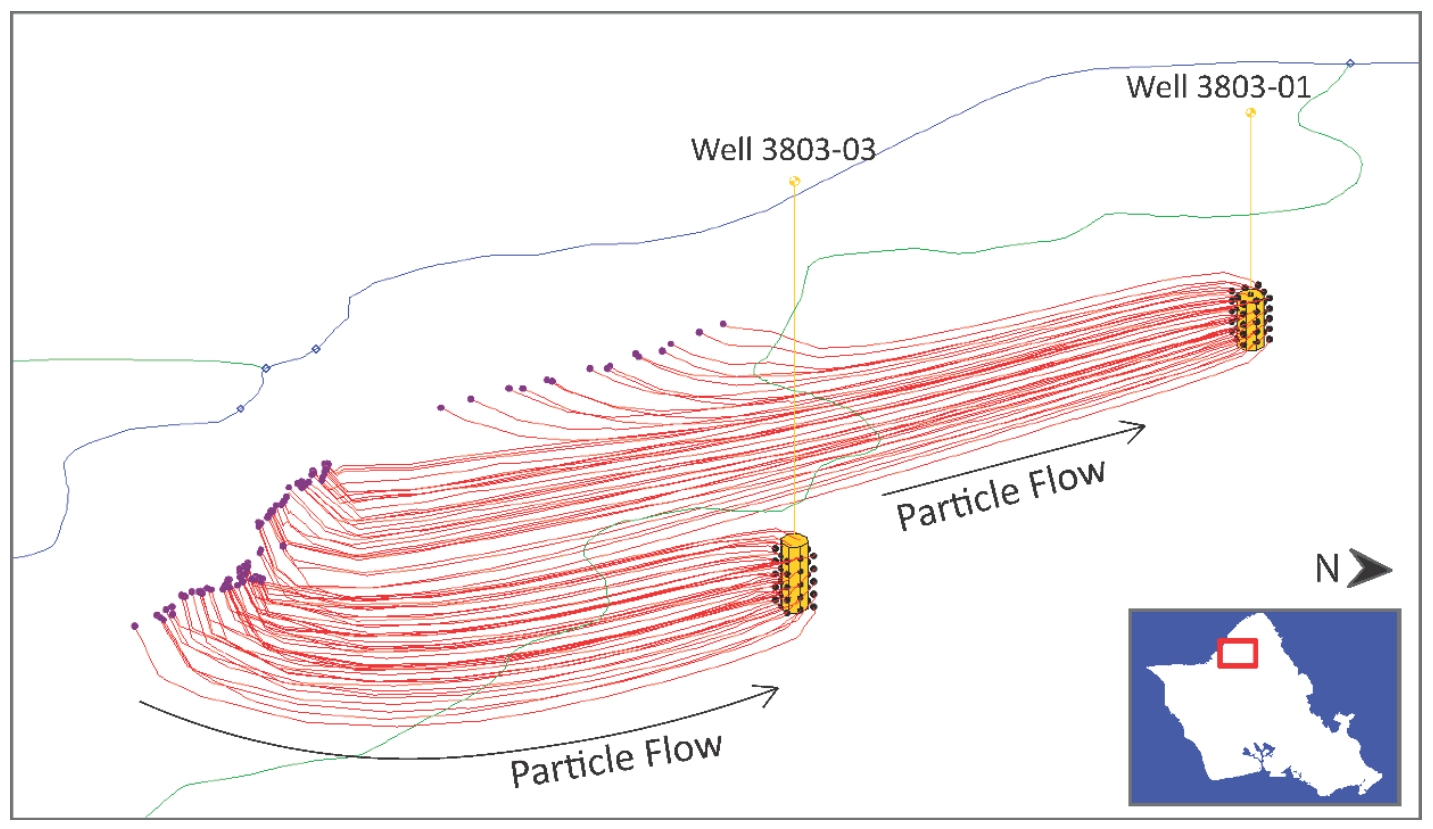

Figure 12. Backwards particle tracking analysis. Image is oblique, looking to the southwest. This figure uses $5 \mathrm{X}$ vertical exaggeration. Blue lines represent perennial streams and dark green lines represent ephemeral streams. Purple dots are the beginning of each flow line. $\mathrm{Kh} / \mathrm{Kv}$ is 20 . 
Table 1. Probable habitats of non-tuberculous Mycobacterium

\begin{tabular}{|c|c|c|}
\hline Habitat & Physiological Determinants & Reference \\
\hline Natural waters & $\begin{array}{c}\text { Oligotrophic (low nutrient } \\
\text { environment), biofilm formation }\end{array}$ & $\begin{array}{c}\text { (Falkinham III et al., 1980; } \\
\text { Reyn et al., 1993) }\end{array}$ \\
\hline $\begin{array}{l}\text { Drinking water distribution } \\
\text { systems }\end{array}$ & $\begin{array}{l}\text { Oligotrophic, biofilm formation, } \\
\text { disinfectant-resistance }\end{array}$ & $\begin{array}{c}\text { (Covert et al., 1999; } \\
\text { Falkinham III et al., 2001) }\end{array}$ \\
\hline $\begin{array}{l}\text { Biofilms in drinking water } \\
\text { distribution systems }\end{array}$ & $\begin{array}{c}\text { Oligotrophic, biofilm formation, } \\
\text { disinfectant-resistance }\end{array}$ & $\begin{array}{l}\text { (Falkinham III et al., 2001; } \\
\text { Torvinen et al., 2004) }\end{array}$ \\
\hline $\begin{array}{l}\text { Building, hospital, and } \\
\text { household plumbing }\end{array}$ & $\begin{array}{c}\text { Oligotrophic, biofilm formation, } \\
\text { disinfectant-resistance, thermal } \\
\text { tolerance }\end{array}$ & $\begin{array}{c}\text { (Moulin et al., 1988; } \\
\text { Wallace et al., 1998; } \\
\text { Nishiuchi et al., 2007; } \\
\text { Falkinham III et al., 2008) }\end{array}$ \\
\hline Hot tubs and spas & $\begin{array}{l}\text { Oligotrophic (low nutrient } \\
\text { environment), biofilm formation }\end{array}$ & $\begin{array}{l}\text { (Embil et al., 1997; Kahana } \\
\text { et al., 1997; Mangione et } \\
\text { al., 2001; Marras et al., } \\
\text { 2005; Falkinham III, 2009) }\end{array}$ \\
\hline $\begin{array}{c}\text { Natural (e.g. dust) and } \\
\text { household/building aerosols }\end{array}$ & $\begin{array}{c}\text { Particle attachment and } \\
\text { hydrophobic NTM cells enriched } \\
\text { in aerosols }\end{array}$ & (Falkinham III et al., 2008) \\
\hline Natural Soils and Potting Soils & $\begin{array}{c}\text { Particle attachment, oligotrophic, } \\
\text { humic and fulvic acid growth } \\
\text { stimulation }\end{array}$ & (De Groote et al., 2006) \\
\hline
\end{tabular}


Table 2. Kolmogorov-Smirnov tests for HVO 2018 soils, Oahu 2018 streams, and Hawaii 2012 soils

\begin{tabular}{|c|c|c|c|c|c|}
\hline \multicolumn{2}{|c|}{ HVO 2018 Soils } & \multicolumn{2}{|c|}{ Oahu 2018 Streams } & \multicolumn{2}{|c|}{ Hawaii 2012 Soils } \\
\hline Variable & $\mathrm{p}$ & Variable & $\mathrm{p}$ & Variable & $\mathrm{p}$ \\
\hline PCA 1 Axis & 0.002 & PCA 1 Axis & 0.04 & PCA 1 Axis & 0.85 \\
\hline PCA 2 Axis & 0.092 & PCA 2 Axis & 0.47 & PCA 2 Axis & 0.59 \\
\hline- & - & PCA 6 Axis & 0.04 & - & - \\
\hline NMDS 1 Axis & 0.005 & NMDS 1 Axis & 0.47 & NMDS 1 Axis & 0.69 \\
\hline NMDS 2 Axis & 0.031 & NMDS 2 Axis & 0.91 & NMDS 2 Axis & 0.61 \\
\hline TOC & 0.000009 & $\mathrm{Mg}^{2+}$ & 0.038 & Iron Oxides & 0.337 \\
\hline $\mathrm{SiO}_{2}$ & 0.001032 & $\mathrm{SO}_{4}{ }^{2-}$ & 0.038 & Feldspar & 0.519 \\
\hline $\mathrm{Fe}_{2} \mathrm{O}_{3}$ & 0.001032 & $\mathrm{pH}$ & 0.158 & Clays & 0.564 \\
\hline Sc & 0.002827 & $\mathrm{~F}^{-}$ & 0.158 & Goethite & 0.564 \\
\hline MnO & 0.005743 & $\mathrm{Ba}$ & 0.158 & $\mathrm{pH}$ & 0.670 \\
\hline $\mathbf{P}_{2} \mathbf{O}_{5}$ & 0.007209 & $\mathrm{Li}$ & 0.158 & Organic matter & 0.797 \\
\hline $\mathrm{TiO}_{2}$ & 0.011205 & $\mathrm{Mn}$ & 0.158 & Rainfall & 0.931 \\
\hline $\mathbf{V}$ & 0.013876 & $\mathrm{Sr}$ & 0.158 & Gibbsite & 0.949 \\
\hline Sm & 0.020993 & $\mathrm{Ti}$ & 0.158 & Carbonate & 0.993 \\
\hline $\mathbf{Z r}$ & 0.025648 & $\mathrm{Zn}$ & 0.158 & Quartz & 0.998 \\
\hline $\mathrm{Cr}$ & 0.031194 & $\mathrm{HCO}_{3}^{-}$ & 0.474 & & \\
\hline $\mathbf{G a}$ & 0.031194 & $\mathrm{Br}^{-}$ & 0.474 & & \\
\hline pH & 0.045525 & $\mathrm{P}$ & 0.474 & & \\
\hline MgO & 0.045525 & TOC & 0.474 & & \\
\hline $\mathrm{K}_{2} \mathrm{O}$ & 0.054626 & $\mathrm{Tl}$ & 0.474 & & \\
\hline $\mathrm{CaO}$ & 0.065253 & V & 0.474 & & \\
\hline $\mathrm{Pb}$ & 0.065253 & $\mathrm{Ca}^{2+}$ & 0.705 & & \\
\hline $\mathrm{Y}$ & 0.077596 & $\mathrm{Na}^{+}$ & 0.705 & & \\
\hline $\mathrm{Nb}$ & 0.091858 & $\mathrm{Al}$ & 0.705 & & \\
\hline $\mathrm{Ni}$ & 0.091858 & As & 0.705 & & \\
\hline $\mathrm{Sr}$ & 0.091858 & $\mathrm{~Pb}$ & 0.705 & & \\
\hline $\mathrm{Cu}$ & 0.229731 & $\mathrm{SiO}_{2}$ & 0.705 & & \\
\hline $\mathrm{Zn}$ & 0.263327 & $\mathrm{~K}^{+}$ & 0.909 & & \\
\hline $\mathrm{La}$ & 0.340932 & $\mathrm{Cl}^{-}$ & 0.909 & & \\
\hline $\begin{array}{c}\text { Mafic } \\
\text { Silicates }\end{array}$ & 0.384973 & $\mathrm{NO}_{3}^{-}$ & 0.909 & & \\
\hline $\mathrm{Ba}$ & 0.432366 & Co & 0.909 & & \\
\hline $\mathrm{Rb}$ & 0.432366 & $\mathrm{Cr}$ & 0.909 & & \\
\hline $\mathrm{Ce}$ & 0.482849 & $\mathrm{Fe}$ & 0.909 & & \\
\hline $\mathrm{Na}_{2} \mathrm{O}$ & 0.535989 & $\mathrm{Ni}$ & 0.909 & & \\
\hline $\mathrm{Al}_{2} \mathrm{O}_{3}$ & 0.647494 & $\mathrm{Cu}$ & 0.994 & & \\
\hline Feldspar & 0.759043 & Mo & 0.994 & & \\
\hline $\mathrm{Nd}$ & 0.811375 & & & & \\
\hline Iron Oxides & 0.859253 & & & & \\
\hline
\end{tabular}


Table 3. Logistic regression, a) model selection and b) model averaged coefficients and confidence intervals of Hawaii 2012 soil chemistry

\begin{tabular}{|c|c|c|c|c|c|c|c|c|c|}
\hline \multirow[b]{2}{*}{$\begin{array}{c}\text { Model } \\
\#\end{array}$} & \multicolumn{7}{|c|}{ Coefficients } & \multirow[b]{2}{*}{$\mathrm{AICc}$} & \multirow[b]{2}{*}{$\begin{array}{l}\text { Model } \\
\text { Weight }\end{array}$} \\
\hline & Intercept & Feldspar & Goethite & Gibbsite & $\begin{array}{l}\text { Iron } \\
\text { Oxide }\end{array}$ & $\begin{array}{l}\text { Organic } \\
\text { Matter }\end{array}$ & $\mathrm{pH}$ & & \\
\hline 1 & -1.29 & - & - & - & - & - & - & 55.3 & 0.09 \\
\hline 2 & -1.72 & 0.03 & - & - & - & - & - & 55.7 & 0.08 \\
\hline 4 & -2.51 & 0.04 & 0.05 & - & - & & - & 56.3 & 0.06 \\
\hline 17 & -0.87 & - & - & - & - & -0.12 & - & 56.8 & 0.04 \\
\hline 5 & -1.03 & - & - & -0.07 & - & - & - & 56.8 & 0.04 \\
\hline 3 & -1.56 & - & 0.02 & - & - & - & - & 57.0 & 0.04 \\
\hline 33 & -0.47 & - & - & - & - & - & -0.12 & 57.3 & 0.03 \\
\hline 18 & -1.31 & 0.03 & - & - & - & -0.11 & - & 57.4 & 0.03 \\
\hline 6 & -1.46 & 0.03 & - & -0.07 & - & - & - & 57.4 & 0.03 \\
\hline 9 & -1.27 & - & - & - & 0.00 & - & - & 57.4 & 0.03 \\
\hline 10 & -2.35 & 0.04 & - & - & 0.03 & - & - & 57.5 & 0.03 \\
\hline 8 & -2.26 & 0.04 & 0.05 & -0.09 & - & - & - & 57.8 & 0.03 \\
\hline 20 & -2.09 & 0.04 & 0.05 & - & - & -0.13 & - & 57.8 & 0.03 \\
\hline 34 & -1.02 & 0.03 & - & - & - & - & -0.10 & 57.9 & 0.03 \\
\hline 21 & -0.55 & - & - & -0.07 & - & -0.13 & - & 58.3 & 0.02 \\
\hline 7 & -1.31 & - & 0.03 & -0.08 & - & - & - & 58.4 & 0.02 \\
\hline 19 & -1.14 & - & 0.03 & - & - & -0.13 & - & 58.4 & 0.02 \\
\hline 12 & -2.75 & 0.04 & 0.04 & - & 0.01 & - & - & 58.6 & 0.02 \\
\hline 36 & -3.15 & 0.04 & 0.05 & - & - & - & 0.08 & 58.6 & 0.02 \\
\hline 49 & 0.48 & - & - & - & - & -0.13 & -0.19 & 58.8 & 0.02 \\
\hline 37 & -0.11 & - & - & -0.07 & - & - & -0.13 & 58.9 & 0.02 \\
\hline 25 & -0.88 & - & - & - & 0.00 & -0.12 & - & 59.0 & 0.01 \\
\hline 13 & -1.04 & - & - & -0.07 & 0.00 & - & - & 59.1 & 0.01 \\
\hline 11 & -1.37 & - & 0.03 & - & -0.01 & - & - & 59.1 & 0.01 \\
\hline 22 & -1.03 & 0.03 & - & -0.07 & - & -0.11 & - & 59.1 & 0.01 \\
\hline 26 & -1.99 & 0.04 & - & - & 0.03 & -0.12 & - & 59.2 & 0.01 \\
\hline 35 & -1.17 & - & 0.02 & - & - & - & -0.05 & 59.2 & 0.01 \\
\hline 14 & -2.09 & 0.03 & - & -0.07 & 0.03 & - & - & 59.3 & 0.01 \\
\hline 24 & -1.82 & 0.04 & 0.06 & -0.09 & - & -0.13 & - & 59.3 & 0.01 \\
\hline 50 & -0.11 & 0.03 & - & - & - & -0.12 & -0.16 & 59.5 & 0.01 \\
\hline 41 & -0.44 & - & - & - & 0.00 & - & -0.12 & 59.6 & 0.01 \\
\hline 38 & -0.64 & 0.03 & - & -0.07 & - & - & -0.12 & 59.6 & 0.01 \\
\hline 23 & -0.83 & - & 0.03 & -0.09 & - & -0.14 & - & 59.8 & 0.01 \\
\hline
\end{tabular}




\begin{tabular}{|c|c|c|c|c|c|}
\hline \multirow[b]{2}{*}{ b } & \multirow[b]{2}{*}{$\begin{array}{c}\text { Model Averaged } \\
\text { Coefficient }\end{array}$} & \multicolumn{2}{|c|}{ 95\% Confidence Interval } & \multirow[b]{2}{*}{$1 \sigma$} & \multirow[b]{2}{*}{$\begin{array}{l}\% \text { of } 1 \sigma \\
\text { Overlap } \\
\text { of Zero }\end{array}$} \\
\hline & & Lower Limit & Upper Limit & & \\
\hline Intercept & -1.41 & -4.42 & 1.59 & 1.504 & 105.9 \\
\hline Feldspar & 0.02 & -0.03 & 0.06 & 0.023 & 130.6 \\
\hline Goethite & 0.01 & -0.04 & 0.07 & 0.028 & 155.8 \\
\hline Organic Matter & -0.03 & -0.23 & 0.16 & 0.096 & 165.8 \\
\hline Gibbsite & -0.02 & -0.14 & 0.10 & 0.058 & 166.2 \\
\hline $\mathrm{pH}$ & -0.02 & -0.35 & 0.31 & 0.165 & 189.5 \\
\hline Iron Oxides & 0.00 & -0.03 & 0.04 & 0.018 & 190.0 \\
\hline
\end{tabular}

Table 4. Logistic regression, a) model selection and b) model averaged coefficients and confidence intervals of HVO soil chemistry.

\begin{tabular}{|c|c|c|c|c|c|c|c|c|}
\hline \multirow{2}{*}{$\begin{array}{c}\text { a } \\
\text { Model \# }\end{array}$} & \multicolumn{3}{|c|}{ Coefficients } & \multirow[b]{2}{*}{$\begin{array}{l}\text { Degrees } \\
\text { of } \\
\text { Freedom }\end{array}$} & \multirow[b]{2}{*}{$\begin{array}{c}\text { Log } \\
\text { Likelihood }\end{array}$} & \multirow[b]{2}{*}{$\mathrm{AICc}$} & \multirow[b]{2}{*}{ Delta } & \multirow[b]{2}{*}{$\begin{array}{c}\text { Model } \\
\text { Weight }\end{array}$} \\
\hline & Intercept & $\mathrm{P}_{2} \mathrm{O}_{5}$ & TOC & & & & & \\
\hline 4 & -5.43 & 15.01 & 0.81 & 3 & -12.1 & 31.1 & 0.0 & 0.50 \\
\hline 3 & -2.13 & - & 1.06 & 2 & -13.5 & 31.4 & 0.3 & 0.43 \\
\hline 2 & -8.58 & 34.51 & - & 2 & -15.2 & 34.9 & 3.8 & 0.08 \\
\hline
\end{tabular}

\begin{tabular}{|c|c|c|c|c|c|}
\hline \multirow[b]{2}{*}{ b } & \multirow[b]{2}{*}{$\begin{array}{c}\text { Model Averaged } \\
\text { Coefficient }\end{array}$} & \multicolumn{2}{|c|}{ 95\% Confidence Interval } & \multirow[b]{2}{*}{$1 \sigma$} & \multirow[b]{2}{*}{$\begin{array}{l}\% \text { of } 10 \\
\text { Overlap } \\
\text { of Zero }\end{array}$} \\
\hline & & Lower Limit & Upper Limit & & \\
\hline Intercept & -4.26 & -10.75 & 2.22 & 3.244 & 68.5 \\
\hline TOC & 0.86 & -0.14 & 1.85 & 0.498 & 28.0 \\
\hline $\mathrm{P}_{2} \mathrm{O}_{5}$ & 10.09 & -19.54 & 39.72 & 14.816 & 131.9 \\
\hline
\end{tabular}


Table 5. Model calibration flux comparison

\begin{tabular}{|c|c|c|c|c|c|c|}
\hline & $\begin{array}{c}\text { Eastern } \\
\text { Boundary } \\
\text { Flux }\left(\mathrm{m}^{3} / \mathrm{d}\right)\end{array}$ & $\begin{array}{c}\text { Southern } \\
\text { Boundary } \\
\text { Flux }\left(\mathrm{m}^{3} / \mathrm{d}\right)\end{array}$ & $\begin{array}{c}\text { Coastal } \\
\text { Boundary } \\
\text { Flux }\left(\mathrm{m}^{3} / \mathrm{d}\right)\end{array}$ & $\begin{array}{l}\text { Recharge } \\
\text { Flux }\left(\mathrm{m}^{3} / \mathrm{d}\right)\end{array}$ & $\begin{array}{l}\text { River } \\
\text { Flux } \\
\left(\mathrm{m}^{3} / \mathrm{d}\right)\end{array}$ & $\begin{array}{c}\text { Perennial } \\
\text { Stream } \\
\text { Flux }\left(\mathrm{m}^{3} / \mathrm{d}\right)\end{array}$ \\
\hline $\begin{array}{c}\text { Rotzoll and El- } \\
\text { Kadi, } 2007 \\
\text { (NAVFAC) }\end{array}$ & 155,201 & 136,274 & $-386,112$ & 90,849 & 0 & 0 \\
\hline $\begin{array}{c}\text { This Study } \\
\mathrm{Kh} / \mathrm{Kv}=20\end{array}$ & 155,506 & 137,727 & $-386,982$ & 91,967 & 51,523 & $-47,439$ \\
\hline $\begin{array}{c}\text { This Study } \\
\mathrm{Kh} / \mathrm{Kv}=200\end{array}$ & 155,506 & 137,727 & $-393,543$ & 91,967 & 51,520 & $-40,878$ \\
\hline $\begin{array}{c}\% \text { Difference } \\
\mathrm{Kh} / \mathrm{Kv}=20 \\
\end{array}$ & $0.2 \%$ & $1.05 \%$ & $0.22 \%$ & $1.22 \%$ & - & - \\
\hline $\begin{array}{l}\% \text { Difference } \\
\mathrm{Kh} / \mathrm{Kv}=200\end{array}$ & $0.2 \%$ & $1.05 \%$ & $1.89 \%$ & $1.22 \%$ & - & - \\
\hline
\end{tabular}


Appendix A. 2018 Oahu water chemistry

\begin{tabular}{|c|c|c|c|c|c|c|c|c|c|c|c|c|c|}
\hline \multirow[t]{2}{*}{ Sample name } & \multirow[t]{2}{*}{$\begin{array}{c}\text { Temp } \\
\left({ }^{\circ} \mathrm{C}\right)\end{array}$} & \multirow[t]{2}{*}{$\begin{array}{l}\text { Cond. } \\
\mathrm{mS} / \mathrm{cm}\end{array}$} & $\mathrm{Ca}^{2+}$ & \multirow{2}{*}{$\begin{array}{l}\mathbf{M g}^{2+} \\
\mathrm{mg} / \mathrm{L}\end{array}$} & \multirow{2}{*}{$\begin{array}{l}\mathbf{N a}^{\mathbf{1}^{+}} \\
\mathrm{mg} / \mathrm{L}\end{array}$} & \multirow{2}{*}{$\begin{array}{c}\mathbf{K}^{\mathbf{1 +}} \\
\mathrm{mg} / \mathrm{L}\end{array}$} & \multirow{2}{*}{$\begin{array}{c}\mathbf{H C O}_{3}{ }^{{ }^{1-}} \\
\mathrm{mg} / \mathrm{L}\end{array}$} & \multirow{2}{*}{$\begin{array}{c}\mathbf{F}^{1-} \\
\mathrm{mg} / \mathrm{L}\end{array}$} & \multirow{2}{*}{$\begin{array}{l}\mathbf{C l}^{1-} \\
\mathrm{mg} / \mathrm{L}\end{array}$} & \multirow{2}{*}{$\begin{array}{c}\mathbf{B} \mathbf{r}^{1-} \\
\mathrm{mg} / \mathrm{L}\end{array}$} & \multirow{2}{*}{$\begin{array}{l}\mathbf{N O}^{3-} \\
\mathrm{mg} / \mathrm{L}\end{array}$} & \multirow{2}{*}{$\begin{array}{l}\mathbf{S O}_{4}{ }^{2-} \\
\mathrm{mg} / \mathrm{L}\end{array}$} & \multirow[t]{2}{*}{$\begin{array}{c}\% \text { Charge } \\
\text { Balance }\end{array}$} \\
\hline & & & $\mathrm{mg} / \mathrm{L}$ & & & & & & & & & & \\
\hline \multicolumn{14}{|c|}{ Oahu samples collected Jan 22-27, 2018} \\
\hline 18-STR-1 & 20.9 & 96.72 & 1.74 & 4.08 & 11.38 & 0.28 & 13.53 & 0.01 & 20.06 & 0.02 & 0.08 & 2.77 & $4.35 \%$ \\
\hline 18-STR-2 & 21.7 & 176.50 & 7.70 & 9.59 & 14.37 & 0.86 & 51.45 & 0.04 & 23.43 & 0.05 & 0.12 & 5.73 & $5.58 \%$ \\
\hline 18-STR-3 & 21.3 & 162.01 & 6.95 & 6.12 & 16.24 & 0.90 & 34.87 & 0.03 & 26.55 & 0.05 & 0.17 & 5.40 & $4.72 \%$ \\
\hline 18-STR-4 & 21.8 & 271.23 & 11.09 & 9.80 & 32.34 & 1.00 & 81.69 & 0.07 & 35.58 & 0.11 & 0.40 & 5.92 & $5.97 \%$ \\
\hline 18-STR-5 & 21.4 & 230.68 & 10.55 & 9.32 & 23.12 & 1.13 & 60.72 & 0.05 & 34.62 & 0.09 & 0.20 & 0.00 & $8.11 \%$ \\
\hline 18-STR-6 & 22.3 & 78.72 & 2.75 & 2.25 & 8.73 & 0.79 & 10.49 & 0.01 & 15.08 & 0.00 & 0.07 & 2.56 & $5.11 \%$ \\
\hline 18-STR-7 & 21.4 & 117.19 & 6.53 & 4.92 & 10.41 & 0.67 & 38.04 & 0.02 & 13.35 & 0.00 & 0.14 & 2.42 & $6.52 \%$ \\
\hline 18-STR-8 & - & - & - & - & - & - & - & - & - & - & - & - & - \\
\hline 18-STR-9 & 21.6 & 161.83 & 7.84 & 6.72 & 14.60 & 1.33 & 39.26 & 0.03 & 23.07 & 0.03 & 0.31 & 5.54 & $6.49 \%$ \\
\hline 18-STR-10 & 19.1 & 110.76 & 6.71 & 3.01 & 9.19 & 4.03 & 27.07 & 0.04 & 12.51 & 0.01 & 0.40 & 4.69 & $9.17 \%$ \\
\hline 18-STR-11 & 20.4 & 89.52 & 2.91 & 3.11 & 9.62 & 0.96 & 17.07 & 0.01 & 15.49 & 0.00 & 0.08 & 4.69 & $1.72 \%$ \\
\hline 18-STR-12 & 23.8 & 89.42 & 2.13 & 1.99 & 10.71 & 1.43 & 10.24 & 0.02 & 14.24 & 0.01 & 0.06 & 3.45 & $9.14 \%$ \\
\hline 18-STR-13 & 21.0 & 230.52 & 14.10 & 11.08 & 18.39 & 1.14 & 87.30 & 0.05 & 22.91 & 0.06 & 0.21 & 5.84 & $5.14 \%$ \\
\hline 18-STR-14 & 21.2 & 182.76 & 8.65 & 8.27 & 16.76 & 0.68 & 58.53 & 0.04 & 23.32 & 0.07 & 0.08 & 3.61 & $4.58 \%$ \\
\hline 18-STR-15 & 21.7 & 153.95 & 9.20 & 6.61 & 12.94 & 0.95 & 53.65 & 0.03 & 16.23 & 0.02 & 0.15 & 3.31 & $6.00 \%$ \\
\hline 18-STR-16 & 21.9 & 157.10 & 9.18 & 7.03 & 13.75 & 0.89 & 58.28 & 0.03 & 16.09 & 0.02 & 0.13 & 2.77 & $5.97 \%$ \\
\hline 18-STR-17 & 20.1 & 101.09 & 0.90 & 1.68 & 15.30 & 1.13 & 2.32 & 0.01 & 25.09 & 0.11 & 0.06 & 0.00 & $7.92 \%$ \\
\hline \multicolumn{14}{|c|}{ Oahu samples collected Feb 19-21, 2018} \\
\hline 18-KAR-01 & 20.8 & 57.54 & 1.60 & 4.01 & 11.05 & 0.23 & 14.63 & 0.01 & 19.66 & 0.05 & 0.07 & 3.01 & $2.08 \%$ \\
\hline 18-KAR-02 & 20.7 & 82.40 & 6.68 & 7.08 & 12.71 & 1.18 & 37.55 & 0.03 & 20.37 & 0.06 & 0.11 & 5.32 & $6.92 \%$ \\
\hline 18-KAR-03 & 20.8 & 100.08 & 7.07 & 6.10 & 16.31 & 0.90 & 35.36 & 0.02 & 26.65 & 0.08 & 0.24 & 6.02 & $4.08 \%$ \\
\hline 18-KAR-04 & 22.2 & 270.39 & 11.21 & 10.20 & 32.70 & 1.01 & 83.89 & 0.05 & 35.83 & 0.13 & 0.43 & 6.19 & $5.98 \%$ \\
\hline 18-KAR-05 & 21.5 & 230.68 & 10.56 & 9.58 & 23.00 & 1.11 & 65.35 & 0.04 & 34.48 & 0.11 & 0.24 & 5.00 & $4.21 \%$ \\
\hline 18-KAR-06 & 19.3 & 71.18 & 4.26 & 2.74 & 11.68 & 1.03 & 17.80 & 0.01 & 18.22 & 0.05 & 0.15 & 4.23 & $4.00 \%$ \\
\hline 18-KAR-07 & 20.5 & 105.02 & 5.57 & 4.39 & 9.54 & 0.69 & 31.46 & 0.02 & 13.35 & 0.00 & 0.14 & 3.18 & $5.44 \%$ \\
\hline 18-KAR-08 & - & - & - & - & - & - & - & - & - & - & - & - & - \\
\hline 18-KAR-09 & 21.5 & 189.83 & 9.61 & 8.45 & 16.48 & 1.45 & 49.26 & 0.03 & 26.67 & 0.09 & 0.55 & 8.17 & $5.11 \%$ \\
\hline 18-KAR-10 & - & - & - & - & - & - & - & - & - & - & - & - & - \\
\hline 18-KAR-11 & 19.4 & 57.97 & 3.40 & 3.81 & 10.18 & 0.86 & 23.41 & 0.02 & 15.47 & 0.05 & 0.07 & 3.17 & $3.21 \%$ \\
\hline 18-KAR-12 & 23.0 & 44.99 & 2.22 & 2.04 & 9.91 & 1.33 & 15.12 & 0.02 & 13.77 & 0.00 & 0.15 & 5.33 & $-0.48 \%$ \\
\hline 18-KAR-13 & 20.8 & 116.98 & 12.49 & 10.44 & 17.17 & 1.93 & 72.18 & 0.04 & 23.84 & 0.08 & 0.53 & 7.17 & $6.11 \%$ \\
\hline 18-KAR-14 & 21.8 & 160.96 & 7.36 & 7.03 & 15.75 & 0.77 & 44.63 & 0.04 & 23.72 & 0.08 & 0.07 & 3.75 & $5.37 \%$ \\
\hline 18-KAR-15 & 20.9 & 93.38 & 10.82 & 7.97 & 13.07 & 1.43 & 61.70 & 0.03 & 17.01 & 0.05 & 0.13 & 4.67 & $6.15 \%$ \\
\hline 18-KAR-16 & 20.8 & 96.93 & 8.43 & 7.80 & 15.27 & 1.31 & 44.14 & 0.02 & 25.43 & 0.07 & 0.45 & 4.56 & $6.50 \%$ \\
\hline 18-KAR-17 & 18.2 & 59.12 & 0.90 & 1.89 & 13.49 & 0.92 & 0.73 & 0.00 & 23.73 & 0.10 & 0.44 & 5.77 & $0.05 \%$ \\
\hline 18-KAR-18 & 20.8 & 218.66 & 28.77 & 16.64 & 24.38 & 2.96 & 156.31 & 0.12 & 32.18 & 0.08 & 0.30 & 7.11 & $4.11 \%$ \\
\hline
\end{tabular}

\begin{tabular}{|c|c|c|c|c|c|c|c|c|c|c|c|c|c|}
\hline \multicolumn{14}{|c|}{ Oahu samples collected Aug 2-7, 2018} \\
\hline 18-KRM-01 & 22.2 & 99.76 & 1.81 & 4.29 & 10.65 & 0.20 & 16.22 & 0.01 & 19.09 & 0.22 & 0.01 & 2.02 & $3.50 \%$ \\
\hline 18-KRM-02 & 23.8 & 178.93 & 7.56 & 9.67 & 13.86 & 0.62 & 52.31 & 0.04 & 22.78 & 0.06 & 0.01 & 5.30 & $5.23 \%$ \\
\hline 18-KRM-03 & 24.4 & 154.11 & 6.76 & 5.62 & 14.57 & 1.13 & 33.53 & 0.03 & 23.73 & 0.04 & 0.17 & 4.79 & $5.00 \%$ \\
\hline 18-KRM-04 & 22.7 & 272.26 & 11.12 & 9.70 & 30.66 & 0.92 & 82.42 & 0.13 & 36.49 & 0.11 & 0.32 & 5.98 & $3.66 \%$ \\
\hline 18-KRM-05 & 22.6 & 229.31 & 10.69 & 9.44 & 22.95 & 1.06 & 65.96 & 0.05 & 33.71 & 0.10 & 0.15 & 4.69 & $4.46 \%$ \\
\hline 18-KRM-06 & 24.9 & 87.36 & 3.04 & 2.53 & 9.09 & 0.73 & 15.12 & 0.02 & 13.76 & 0.05 & 0.04 & 2.64 & $5.49 \%$ \\
\hline 18-KRM-07 & 23.0 & 133.61 & 7.71 & 5.66 & 11.15 & 0.59 & 48.77 & 0.03 & 13.09 & 0.03 & 0.02 & 2.16 & $5.23 \%$ \\
\hline 18-KRM-08 & - & - & - & - & - & - & - & - & - & - & - & - & - \\
\hline 18-KRM-09 & 23.2 & 215.17 & 10.26 & 10.50 & 17.60 & 1.17 & 66.45 & 0.05 & 22.38 & 0.15 & 1.18 & 8.73 & $6.00 \%$ \\
\hline 18-KRM-10 & - & - & - & - & - & - & - & - & - & - & - & - & - \\
\hline 18-KRM-11 & 23.7 & 115.25 & 4.05 & 4.67 & 11.21 & 1.06 & 34.51 & 0.02 & 13.72 & 0.02 & 0.03 & 2.89 & $4.12 \%$ \\
\hline 18-KRM-12 & 28.4 & 57.93 & 1.36 & 1.53 & 6.87 & 0.67 & 6.46 & 0.01 & 9.70 & 0.02 & 0.02 & 1.56 & $10.41 \%$ \\
\hline 18-KRM-13 & 23.7 & 228.45 & 13.75 & 10.93 & 17.58 & 1.16 & 87.91 & 0.05 & 21.79 & 0.06 & 0.11 & 5.93 & $4.28 \%$ \\
\hline 18-KRM-14 & 24.3 & 170.35 & 7.69 & 7.42 & 16.05 & 0.73 & 49.26 & 0.05 & 21.62 & 0.07 & 0.03 & 4.47 & $6.11 \%$ \\
\hline 18-KRM-15 & 22.6 & 163.30 & 9.28 & 6.59 & 12.96 & 0.93 & 58.77 & 0.04 & 15.78 & 0.05 & 0.07 & 3.12 & $3.77 \%$ \\
\hline 18-KRM-16 & 23.9 & 149.93 & 9.01 & 6.72 & 13.04 & 0.82 & 59.26 & 0.03 & 13.97 & 0.03 & 0.05 & 2.34 & $5.76 \%$ \\
\hline 18-KRM-17 & 24.1 & 103.89 & 0.91 & 1.70 & 14.79 & 0.85 & 0.73 & 0.00 & 23.85 & 0.12 & 0.01 & 4.96 & $3.70 \%$ \\
\hline 18-KRM-18 & 21.6 & 416.70 & 37.94 & 17.77 & 26.66 & 3.33 & 206.06 & 0.12 & 25.68 & 0.06 & 0.25 & 6.80 & $3.91 \%$ \\
\hline 18-KRM-19 & 25.2 & 77.46 & 1.82 & 2.33 & 9.18 & 0.76 & 11.10 & 0.02 & 13.76 & 0.03 & 0.02 & 2.44 & $5.92 \%$ \\
\hline 18-KRM-20 & 24.3 & 103.66 & 4.00 & 3.26 & 10.91 & 0.68 & 19.02 & 0.02 & 15.74 & 0.06 & 0.03 & 2.88 & $7.96 \%$ \\
\hline
\end{tabular}




\begin{tabular}{|c|c|c|c|c|c|c|c|c|c|c|c|c|c|}
\hline $\begin{array}{c}\text { Sample } \\
\text { name }\end{array}$ & $\begin{array}{c}\text { Al } \\
\mu \mathrm{g} / \mathrm{L} \\
\text { s colle }\end{array}$ & $\begin{array}{c}\text { As } \\
\mu \mathrm{g} / \mathrm{L} \\
\text { d Jan } 2\end{array}$ & $\begin{array}{c}\text { Ba } \\
\mu \mathrm{g} / \mathrm{L} \\
7,2018\end{array}$ & $\begin{array}{c}\text { Co } \\
\mu \mathrm{g} / \mathrm{L}\end{array}$ & $\begin{array}{c}\mathbf{C r} \\
\mu \mathrm{g} / \mathrm{L}\end{array}$ & $\begin{array}{r}\mathbf{C u} \\
\mu \mathrm{g} / \mathrm{L}\end{array}$ & $\begin{array}{c}\mathbf{F e} \\
\mu \mathrm{g} / \mathrm{L}\end{array}$ & $\begin{array}{c}\mathbf{L i} \\
\mu \mathrm{g} / \mathrm{L}\end{array}$ & $\begin{array}{l}\text { Mn } \\
\mu \mathrm{g} / \mathrm{L}\end{array}$ & $\begin{array}{l}\text { Мо } \\
\mu \mathrm{g} / \mathrm{L}\end{array}$ & $\begin{array}{c}\mathbf{N i} \\
\mu \mathrm{g} / \mathrm{L}\end{array}$ & $\begin{array}{c}\mathbf{P} \\
\mu \mathrm{g} / \mathrm{L}\end{array}$ & $\begin{array}{c}\mathbf{P O}_{4} \\
\mu \mathrm{g} / \mathrm{L}\end{array}$ \\
\hline 18-STR-1 & 19.4 & 6.2 & 1.6 & 0.4 & 1 & 0 & 45.40 & 1 & 4.6 & 2.3 & 1 & 6.7 & 0 \\
\hline 18-STR-2 & 10.1 & 5.1 & 5.5 & 0.2 & 0 & 0.4 & 293.60 & 0 & 26.4 & 1.6 & 0.1 & 26.8 & 0 \\
\hline 18-STR-3 & 17.1 & 5.7 & 2.5 & 0 & 0 & 0.3 & 80.90 & 0.4 & 5.6 & 1.3 & 0.2 & 15.3 & 0 \\
\hline 18-STR-4 & 0.1 & 4.9 & 2.7 & 0 & 1.2 & 0.5 & 0.00 & 1.3 & 0.1 & 1.1 & 0 & 140.4 & 76 \\
\hline 18-STR-5 & 8.2 & 4.7 & 1.6 & 0.1 & 2 & 0.6 & 0.20 & 0.8 & 0 & 0.9 & 0 & 62.3 & 3205 \\
\hline 18-STR-6 & 127.7 & 7.1 & 1.6 & 0.3 & 1.5 & 1 & 336.20 & 0.1 & 5.6 & 0.7 & 0.7 & 6.3 & 0 \\
\hline 18-STR-7 & 18.4 & 6.9 & 1 & 0.2 & 0 & 0 & 121.90 & 0 & 18.1 & 0.5 & 0.2 & 13.6 & 0 \\
\hline 18-STR-8 & - & - & - & - & - & - & - & - & - & - & - & - & - \\
\hline 18-STR-9 & 251.7 & 6.3 & 5.9 & 0.1 & 0.6 & 1 & 201.70 & 0 & 2.2 & 0.4 & 0.6 & 35.8 & 0 \\
\hline 18 -STR-10 & 651.4 & 6.1 & 3 & 0.3 & 1.8 & 1.6 & 519.70 & 0.8 & 7.3 & 0.4 & 2.1 & 20.4 & 0 \\
\hline 18-STR-11 & 90 & 6.5 & 1.2 & 0.2 & 0.3 & 1.1 & 72.20 & 0.7 & 0.9 & 0.1 & 0.5 & 5.7 & 0 \\
\hline 18-STR-12 & 31.7 & 7.3 & 0.4 & 0.1 & 0 & 0.9 & 23.60 & 0 & 0.5 & 0.1 & 0.7 & 12.6 & 0 \\
\hline 18-STR-13 & 19.8 & 6.7 & 3.3 & 0.1 & 0.1 & 0 & 111.30 & 0 & 13.8 & 0.1 & 0.4 & 39.1 & 0 \\
\hline 18-STR-14 & 58.9 & 5.9 & 1.9 & 0.5 & 0 & 0.3 & 423.20 & 0.8 & 35.4 & 0.2 & 0.4 & 8.5 & 0 \\
\hline 18-STR-15 & 10.7 & 7.1 & 1.4 & 0 & 0 & 0 & 142.10 & 1.3 & 6.6 & 0 & 0.1 & 42.1 & 0 \\
\hline 18-STR-16 & 11.7 & 5.8 & 1.4 & 0.2 & 0.3 & 0 & 129.20 & 0 & 11.2 & 0 & 0.4 & 25.2 & 0 \\
\hline 18-STR-17 & 23.4 & 6.2 & 3.7 & 0.3 & 0.3 & 0.9 & 33.20 & 1 & 3.9 & 0.1 & 2.4 & 4.8 & 3478 \\
\hline
\end{tabular}

Oahu samples collected Feb 19-21, 2018

\begin{tabular}{|c|c|c|c|c|c|c|c|c|c|c|c|c|c|}
\hline & & & & & & & & & & & & & \\
\hline 18-KAR-01 & 16.1 & 2.1 & 1.4 & 0.2 & 1.6 & 1.8 & 33.60 & 1.3 & 4.9 & 0 & 0.5 & 3.4 & 0 \\
\hline 18-KAR-02 & 43 & 1.3 & 3.9 & 0.2 & 1.5 & 1.7 & 144.40 & 0 & 25.6 & 0 & 0.1 & 17.7 & 0 \\
\hline 18-KAR-03 & 25.6 & 1 & 2.3 & 0.1 & 0.5 & 1.2 & 57.30 & 0 & 5.3 & 0 & 0 & 11.3 & 0 \\
\hline 18-KAR-04 & 7.5 & 0.1 & 2.7 & 0 & 1.9 & 1.6 & 0.00 & 0.9 & 0 & 0 & 0 & 137.9 & 66 \\
\hline 18-KAR-05 & 0 & 0.5 & 1.3 & 0 & 3.2 & 1.4 & 0.00 & 0 & 0 & 0 & 0 & 60.6 & 0 \\
\hline 18-KAR-06 & 84.2 & 0.7 & 3 & 0.3 & 1.7 & 1.6 & 161.90 & 10.5 & 8.1 & 0 & 0.6 & 2.6 & 0 \\
\hline 18-KAR-07 & 9.3 & 1.3 & 1.1 & 0.4 & 1.8 & 0.7 & 79.80 & 6.6 & 17.5 & 0 & 0 & 7.4 & 0 \\
\hline 18-KAR-08 & - & - & - & - & - & - & - & - & - & - & - & - & - \\
\hline 18-KAR-09 & 29 & 0.3 & 6.2 & 0.1 & 0.9 & 1.1 & 27.00 & 0.2 & 1.3 & 0 & 0 & 35.5 & 0 \\
\hline 18-KAR-10 & - & - & - & - & - & - & - & - & - & - & - & - & - \\
\hline 18-KAR-11 & 87 & 1.1 & 1.1 & 0 & 2.1 & 0 & 64.50 & 0 & 1.3 & 0 & 0 & 3.7 & 0 \\
\hline 18-KAR-12 & 12.1 & 0 & 0.5 & 0 & 0.5 & 2.4 & 37.60 & 0 & 1.4 & 0 & 0 & 16.1 & 0 \\
\hline 18-KAR-13 & 30.9 & 0.2 & 4.3 & 0.3 & 1.2 & 1.8 & 59.50 & 0 & 25.2 & 0 & 0.2 & 28.8 & 0 \\
\hline 18-KAR-14 & 46.6 & 1.6 & 1.7 & 0.4 & 2.6 & 1.3 & 124.60 & 0 & 32.5 & 0 & 0 & 3.5 & 0 \\
\hline 18-KAR-15 & 7.3 & 0 & 1.5 & 0 & 1.2 & 0 & 37.10 & 0 & 4.7 & 0 & 0 & 21.6 & 0 \\
\hline 18-KAR-16 & 25.2 & 1.4 & 1.9 & 0.2 & 0.6 & 1.9 & 47.90 & 0 & 23 & 0 & 0 & 8.6 & 0 \\
\hline 18-KAR-17 & 18.7 & 2.1 & 3.7 & 0.5 & 1.1 & 1.7 & 34.10 & 1.1 & 35.1 & 0 & 5.7 & 1.6 & 0 \\
\hline 18-KAR-18 & 10.6 & 0.7 & 15.1 & 0 & 0.1 & 1 & 54.30 & 0 & 16.2 & 0 & 0 & 225.3 & 122 \\
\hline
\end{tabular}

\begin{tabular}{|c|c|c|c|c|c|c|c|c|c|c|c|c|c|}
\hline \multicolumn{14}{|c|}{ Oahu samples collected Aug 2-7, 2018} \\
\hline 18-KRM-01 & 9.3 & bdl & 1.4 & 0.4 & 1.2 & 1.4 & 99.1 & - & 11.9 & bdl & 1.5 & 1.2 & 0 \\
\hline 18-KRM-02 & bdl & bdl & 3.9 & bdl & bdl & bdl & 190.5 & - & 32.6 & bdl & 0.5 & 20.1 & 0 \\
\hline 18-KRM-03 & 92.6 & bdl & 2.2 & bdl & bdl & 1.6 & 151.9 & - & 7.3 & bdl & 0.9 & 17.6 & 0 \\
\hline 18-KRM-04 & bdl & bdl & 2.1 & bdl & 2.8 & 1.5 & -0.5 & - & bdl & bdl & 0.4 & 125.6 & 69.4 \\
\hline 18-KRM-05 & 7.7 & bdl & 1.1 & bdl & 3.8 & bdl & 3.1 & - & bdl & bdl & 0.3 & 57.3 & 19.2 \\
\hline 18-KRM-06 & 9.4 & bdl & 1.1 & bdl & bdl & bdl & 81.1 & - & 4 & bdl & 0.8 & 1.7 & 19.9 \\
\hline 18-KRM-07 & bdl & bdl & 0.8 & bdl & 1.1 & bdl & 106.5 & - & 13.2 & bdl & 0.5 & 8.8 & 0 \\
\hline 18-KRM-08 & - & - & - & - & - & - & - & - & - & - & - & - & - \\
\hline 18-KRM-09 & bdl & bdl & 14.4 & bdl & bdl & bdl & 17.9 & - & 4.6 & bdl & 0.5 & 69.1 & 34.4 \\
\hline 18-KRM-10 & - & - & - & - & - & - & - & - & - & - & - & - & - \\
\hline 18-KRM-11 & 20.3 & bdl & 0.8 & bdl & bdl & 2 & 56.6 & - & 10 & bdl & 0.8 & 4.8 & 0 \\
\hline 18-KRM-12 & 13.1 & bdl & bdl & bdl & 0.6 & 1.6 & 28.9 & - & 0.3 & bdl & 0.5 & 4 & 0 \\
\hline 18-KRM-13 & bdl & bdl & 3 & bdl & bdl & 2.3 & 64.1 & - & 13.3 & bdl & 0.7 & 25.3 & 0 \\
\hline 18-KRM-14 & 23.3 & bdl & 1.7 & 0.2 & 1.3 & 1.2 & 399.9 & - & 20.3 & bdl & 0.8 & 5.6 & 0 \\
\hline 18-KRM-15 & bdl & bdl & 1 & bdl & bdl & bdl & 157.5 & - & 7.6 & bdl & 0.5 & 28.1 & 0 \\
\hline 18-KRM-16 & bdl & bdl & 1 & bdl & bdl & bdl & 101.4 & - & 9.8 & bdl & 0.3 & 16.7 & 11.5 \\
\hline 18-KRM-17 & 11 & bdl & 2.4 & 0.2 & 0.9 & 1.1 & 27.5 & - & 4.4 & bdl & 1.9 & 0.3 & 0 \\
\hline 18-KRM-18 & bdl & bdl & 14.6 & bdl & bdl & 1.4 & 84.3 & - & 22.6 & bdl & 0.4 & 221.2 & 108.6 \\
\hline 18-KRM-19 & 32.3 & bdl & 0.9 & bdl & 0.6 & 1 & 97.5 & - & 2.6 & bdl & 0.8 & 2.7 & 0 \\
\hline 18-KRM-20 & 40.3 & bdl & 2.9 & 0.2 & bdl & 1 & 40.6 & - & 21.4 & bdl & 1.8 & 4.6 & 24 \\
\hline
\end{tabular}




\begin{tabular}{|c|c|c|c|c|c|c|c|c|c|c|c|c|c|c|}
\hline $\begin{array}{c}\text { Sample } \\
\text { name }\end{array}$ & $\begin{array}{r}\mathbf{P b} \\
\mu \mathrm{g} / \mathrm{L}\end{array}$ & $\begin{array}{c}\mathbf{S b} \\
\mu \mathrm{g} / \mathrm{L}\end{array}$ & $\begin{array}{c}\text { Se } \\
\mu \mathrm{g} / \mathrm{L}\end{array}$ & $\begin{array}{l}\mathbf{S i O}_{2} \\
\mathrm{mg} / \mathrm{L}\end{array}$ & $\begin{array}{c}\text { Sn } \\
\mu \mathrm{g} / \mathrm{L}\end{array}$ & $\begin{array}{c}\text { Sr } \\
\mu \mathrm{g} / \mathrm{L}\end{array}$ & $\begin{array}{r}\mathbf{T i} \\
\mu \mathrm{g} / \mathrm{L}\end{array}$ & $\begin{array}{c}\text { Tl } \\
\mu \mathrm{g} / \mathrm{L}\end{array}$ & $\begin{array}{c}\mathbf{V} \\
\mu \mathrm{g} / \mathrm{L}\end{array}$ & $\begin{array}{r}\mathbf{Z n} \\
\mu \mathrm{g} / \mathrm{L}\end{array}$ & $\begin{array}{l}\text { Water } \\
\text { TOC } \\
\mathrm{mg} / \mathrm{L}\end{array}$ & $\begin{array}{c}\text { Soil } \\
\text { TOC } \\
\text { Weight \% }\end{array}$ & $\begin{array}{c}\delta^{18} \mathrm{O} \\
\%\end{array}$ & $\begin{array}{l}\delta D \\
\%\end{array}$ \\
\hline \multicolumn{15}{|c|}{ Oahu samples collected Jan 22-27, 2018} \\
\hline 18-STR-1 & 1.2 & 0 & 0 & 8.29 & 0 & 23.9 & 1.5 & 3.5 & 0.4 & 1 & 2.77 & 5.42 & -2.20 & -3.2 \\
\hline 18-STR-2 & 0.7 & 0 & 0 & 9.43 & 0 & 57.3 & 1 & 4.3 & 1.4 & 0.6 & 0.28 & 8.58 & -2.52 & -5.5 \\
\hline 18-STR-3 & 1.2 & 0 & 0 & 10.00 & 0 & 49.1 & 2 & 4.3 & 1.1 & 1.4 & bdl & 0.45 & -2.39 & -4.2 \\
\hline 18-STR-4 & 6.5 & 0.2 & 0 & 23.66 & 0 & 59.9 & 0.3 & 2.9 & 26.1 & 4 & 2.69 & 3.07 & -3.09 & -10.2 \\
\hline 18-STR-5 & 5.3 & 0 & 0 & 19.81 & 0 & 67.3 & 0.1 & 3.9 & 17.8 & 3.4 & 1.55 & 1.96 & -3.05 & -9.6 \\
\hline 18-STR-6 & 0.2 & 0.1 & 0 & 4.50 & 0 & 14.9 & 19.4 & 3.9 & 0.6 & 0.8 & 3.53 & 2.98 & -1.97 & -1.3 \\
\hline 18-STR-7 & 1.7 & 0 & 0 & 12.84 & 0 & 38.1 & 1.2 & 3.8 & 2.3 & 0.3 & 2.04 & 2.08 & -2.24 & -4.0 \\
\hline 18-STR-8 & - & - & - & - & - & - & - & - & - & - & - & 7.15 & - & - \\
\hline 18-STR-9 & 1.2 & 0 & 0 & 12.14 & 0 & 58.2 & 18.7 & 3.5 & 1.1 & 1.1 & 3.22 & 2.74 & -2.09 & -3.1 \\
\hline 18-STR-10 & 2.8 & 0 & 0 & 13.02 & 0 & 42 & 43 & 3.3 & 2.1 & 2.5 & 3.05 & 5.90 & -2.83 & -6.5 \\
\hline 18-STR-11 & 1.2 & 0 & 0 & 7.01 & 0 & 21.6 & 4.3 & 3.9 & -0.2 & 0.4 & 2.12 & 4.97 & -2.12 & -2.3 \\
\hline 18-STR-12 & 0.8 & 0 & 0 & 7.66 & 0 & 13.2 & 0.6 & 3.2 & 2.4 & 2.1 & 3.93 & 9.33 & -2.00 & -2.7 \\
\hline 18-STR-13 & 3 & 0 & 0 & 17.21 & 0 & 78.9 & 1 & 3.7 & 5.1 & 0.3 & 2.16 & 4.95 & -2.94 & -8.5 \\
\hline 18-STR-14 & 3.1 & 0 & 0 & 16.23 & 0 & 40.1 & 2.6 & 4.2 & 3.1 & 1 & 2.35 & 5.46 & -2.64 & -7.2 \\
\hline 18-STR-15 & 1.9 & 0.1 & 0 & 15.61 & 0 & 53.7 & 0.4 & 3.4 & 4.6 & 0 & 0.88 & 1.88 & -3.04 & -7.8 \\
\hline 18-STR-16 & 2 & 0 & 0 & 15.41 & 0 & 51.5 & 0.7 & 3.7 & 3.7 & 0.8 & 1.81 & 3.14 & -2.98 & -6.5 \\
\hline 18-STR-17 & 0 & 0 & 0 & 2.09 & 0 & 9.6 & 0.9 & 3.7 & 0.6 & 2.4 & 3.32 & 2.50 & -2.65 & -4.2 \\
\hline \multicolumn{15}{|c|}{ Oahu samples collected Feb 19-21, 2018} \\
\hline 18-KAR-01 & 0.6 & 0 & 0 & 9.27 & 0 & 22.3 & 1.2 & 1.5 & 0.5 & 1.2 & 6.26 & 2.79 & -2.52 & -3.5 \\
\hline 18-KAR-02 & 1.1 & 0 & 0 & 9.74 & 0 & 45.1 & 3.1 & 1.5 & 1.4 & 0.8 & 4.23 & 5.36 & -3.33 & -8.7 \\
\hline 18-KAR-03 & 0.7 & 0 & 0 & 11.43 & 0 & 46.3 & 1.9 & 1.4 & 0.9 & 5.7 & 12.9 & 1.99 & -2.91 & -5.3 \\
\hline 18-KAR-04 & 4.7 & 0 & 0 & 34.29 & 0 & 59.1 & 0 & 1 & 25.8 & 2.9 & 2.63 & 1.81 & -3.62 & -10.5 \\
\hline 18-KAR-05 & 3.1 & 0 & 0 & 28.58 & 0.3 & 65 & 0 & 1.4 & 17.7 & 3.9 & 3.46 & 6.64 & -3.58 & -9.5 \\
\hline 18-KAR-06 & 0 & 0 & 0 & 5.02 & 0.2 & 20.3 & 6.2 & 1.4 & 0 & 0.3 & 25 & 0.97 & -3.81 & -12.0 \\
\hline 18-KAR-07 & 1.1 & 0 & 0 & 13.86 & 0 & 29.9 & 0.5 & 1.4 & 0.2 & 1.8 & 3.43 & 5.05 & -2.98 & -5.2 \\
\hline 18-KAR-08 & - & - & - & - & - & - & - & - & - & - & - & 6.83 & - & - \\
\hline 18-KAR-09 & 2.1 & 0 & 0 & 18.77 & 0.1 & 70.3 & 1.7 & 0.9 & 2.4 & 1 & 3.48 & 1.5 & -2.98 & -5.2 \\
\hline 18-KAR-10 & - & - & - & - & - & - & - & - & - & - & - & 5.48 & - & - \\
\hline 18-KAR-11 & 0.4 & 0 & 0 & 9.50 & 0 & 23.9 & 3.1 & 1.4 & 0 & 0.6 & 3.17 & 3.43 & -3.63 & -11.0 \\
\hline 18-KAR-12 & 1.2 & 0 & 0 & 8.88 & 0 & 13.3 & 1.4 & 0.9 & 1.6 & 1.5 & 4.81 & 0.68 & -2.62 & -3.5 \\
\hline 18-KAR-13 & 2.2 & 0 & 0 & 24.21 & 0 & 68.4 & 1.3 & 0.7 & 3 & 0.4 & 3.23 & 2.32 & -3.36 & -8.2 \\
\hline 18-KAR-14 & 1.8 & 0 & 0 & 24.36 & 0.2 & 35.3 & 1.3 & 1.3 & 3.3 & 0.4 & 4.15 & 5.62 & -3.17 & -7.4 \\
\hline 18-KAR-15 & 1.3 & 0 & 0 & 20.87 & 0 & 59.8 & 0.5 & 1.4 & 1.6 & 0 & 3.01 & 1.65 & -3.26 & -6.8 \\
\hline 18-KAR-16 & 1.2 & 0 & 0 & 18.01 & 0 & 48.5 & 1 & 1.8 & 1.5 & 0 & 2.7 & 2.33 & -3.11 & -6.7 \\
\hline 18-KAR-17 & 0 & 0 & 0 & 1.98 & 0 & 9.6 & 0.5 & 1.4 & 0.8 & 1.5 & 3.63 & 1.38 & -3.09 & -6.2 \\
\hline 18-KAR-18 & 1.1 & 0 & 0 & 31.45 & 0 & 293 & 0.8 & 1.3 & 6.8 & 0.3 & 1.81 & 1.63 & -2.91 & -5.7 \\
\hline \multicolumn{15}{|c|}{ Oahu samples collected Aug 2-7, 2018} \\
\hline 18-KRM-01 & 7 & bdl & bdl & 10.54 & bdl & 23.4 & 2.1 & bdl & bdl & 1.2 & 2.93 & 0.39 & -2.46 & -5.03 \\
\hline 18-KRM-02 & 9 & bdl & bdl & 12.50 & bdl & 52.6 & 0.5 & bdl & 0.9 & 0.8 & 7.91 & 2.8 & -2.72 & -6.51 \\
\hline 18-KRM-03 & 6.9 & bdl & bdl & 10.90 & bdl & 45.1 & 13.4 & bdl & 1.3 & 0.3 & 7.73 & 3.57 & -2.49 & -4.54 \\
\hline 18-KRM-04 & 31.5 & bdl & bdl & 43.91 & bdl & 55.4 & 0.3 & bdl & 23.7 & 5.7 & 5.73 & 1.48 & -3.37 & -11.45 \\
\hline 18-KRM-05 & 25.4 & bdl & 1 & 34.77 & bdl & 63.9 & bdl & bdl & 17.4 & 1.2 & 1.93 & 3.08 & -3.3 & -10.06 \\
\hline 18-KRM-06 & 4 & bdl & bdl & 5.65 & bdl & 15.1 & 1.8 & bdl & bdl & 0.7 & 5.59 & 0.66 & -1.93 & -2.22 \\
\hline 18-KRM-07 & 15.3 & bdl & 1.8 & 20.51 & bdl & 41.6 & 0.6 & bdl & 2.1 & 0.6 & 2.27 & 3.28 & -2.57 & -4.96 \\
\hline 18-KRM-08 & - & - & - & - & - & - & - & - & - & - & - & 6.39 & - & - \\
\hline 18-KRM-09 & 16.5 & bdl & bdl & 21.90 & bdl & 90.4 & 0.7 & bdl & 1.8 & 0.5 & 5.29 & 5.45 & -2.45 & -4.79 \\
\hline 18-KRM-10 & - & - & - & - & - & - & - & - & - & - & - & - & - & - \\
\hline 18-KRM-11 & 9 & bdl & bdl & 12.18 & bdl & 29.3 & 1.6 & bdl & bdl & 0.2 & 8.32 & 6.51 & -2.06 & -2.11 \\
\hline 18-KRM-12 & 4.1 & bdl & 1.6 & 5.39 & bdl & 8.6 & 1.8 & bdl & 0.8 & 2.3 & 3.69 & 4.35 & -1.47 & 0.66 \\
\hline 18-KRM-13 & 18.7 & bdl & bdl & 26.05 & bdl & 71.6 & 1 & bdl & 3.3 & bdl & 3.75 & 2.04 & -3.42 & -9.46 \\
\hline 18-KRM-14 & 17 & bdl & bdl & 23.38 & bdl & 34.7 & 1.9 & bdl & 0.7 & 1.1 & 7.05 & 6.61 & -3.08 & -8.25 \\
\hline 18-KRM-15 & 18.2 & bdl & 1.6 & 24.19 & bdl & 50.3 & 0.5 & bdl & 3.3 & 0.1 & 6.68 & 4.04 & -3.47 & -8.59 \\
\hline 18-KRM-16 & 17.2 & bdl & bdl & 23.83 & bdl & 46.6 & 0.7 & bdl & 2.9 & 0.7 & 7.53 & 4.48 & -3.37 & -7.22 \\
\hline 18-KRM-17 & 1.4 & bdl & bdl & 1.80 & bdl & 8.5 & 0.6 & bdl & bdl & 0.9 & 3.29 & 3.25 & -2.85 & -4.67 \\
\hline 18-KRM-18 & 25 & bdl & bdl & 34.98 & bdl & 355.3 & 0.9 & bdl & 8.5 & 0.9 & 3.70 & 2.64 & -2.89 & -5.73 \\
\hline 18-KRM-19 & 3.7 & bdl & 1.8 & 5.43 & bdl & 13.1 & 2.9 & bdl & bdl & 1 & 8.63 & 0.75 & -2.26 & -2.4 \\
\hline 18-KRM-20 & 8.5 & bdl & bdl & 11.99 & bdl & 24.8 & 2.3 & bdl & bdl & 3.8 & 7.21 & 2.1 & -2.37 & -2.92 \\
\hline
\end{tabular}


One sample site (e.g. 18-KAR-10) was collected only for soil because the stream was dry in February. An additional sample (e.g. 18-KAR-18) was collected in February that was not collected in January due to trail conditions. Sample site 10 (e.g. 18-KRM-10) was not collected in August because the water sample was not collected in February. Two additional samples were collected in August in Waimea valley, Oahu (e.g. 18-KRM-19 and 18-KRM-20) to better understand and characterize that area. Due to DNA

sequencing complications, bacterial analyses of the January, February, and August soil samples have yet to be analyzed. 


\section{Appendix B. 2018 HVO soil chemistry}

\begin{tabular}{|c|c|c|c|c|c|c|c|c|c|c|c|c|c|}
\hline Sample & Latitude & Longitude & Date & $\begin{array}{c}\text { Soil TOC } \\
\%\end{array}$ & Soil Type & $\begin{array}{c}\text { NTM } \\
\text { Culture }\end{array}$ & $\mathrm{pH}$ & $\begin{array}{c}\mathrm{SiO}_{2} \\
\text { weight \% }\end{array}$ & $\begin{array}{c}\mathrm{TiO}_{2} \\
\text { weight } \%\end{array}$ & $\begin{array}{c}\mathrm{Al}_{2} \mathrm{O}_{3} \\
\text { weight } \%\end{array}$ & $\begin{array}{c}\mathrm{Fe}_{2} \mathrm{O}_{3} \\
\text { weight } \%\end{array}$ & $\begin{array}{c}\mathrm{MnO} \\
\text { weight \% }\end{array}$ & $\begin{array}{c}\mathrm{MgO} \\
\text { weight \% }\end{array}$ \\
\hline 21 & 19.42614 & -155.255 & $1 / 18 / 2018$ & 0.71 & Andisols & 0 & 5.61 & 48.17 & 2.27 & 12.02 & 13.09 & 0.17 & 10.46 \\
\hline 22 & 19.42382 & -155.256 & $1 / 18 / 2018$ & 4.29 & Andisols & 1 & 5.52 & 45.69 & 2.15 & 11.23 & 12.97 & 0.18 & 11.65 \\
\hline 23 & 19.42393 & -155.256 & $1 / 18 / 2018$ & 1.91 & Andisols & 1 & 5.34 & 45.38 & 2.15 & 11.48 & 12.68 & 0.17 & 10.16 \\
\hline 24 & 19.43806 & -155.235 & $1 / 18 / 2018$ & 2.10 & Andisols & 1 & 5.53 & 45.19 & 2.22 & 11.75 & 14.12 & 0.16 & 9.04 \\
\hline 25 & 19.43666 & -155.236 & $1 / 18 / 2018$ & 1.68 & Andisols & 1 & 5.33 & 48.60 & 2.54 & 12.48 & 12.79 & 0.17 & 7.14 \\
\hline 26 & 19.47099 & -155.261 & $1 / 18 / 2018$ & 0.97 & Andisols & 0 & 6.78 & 43.81 & 2.49 & 14.20 & 14.45 & 0.20 & 8.33 \\
\hline 209 & 19.44308 & -155.28 & $?$ & 4.96 & Andisols & 0 & 5.85 & 41.47 & 1.95 & 10.29 & 11.96 & 0.16 & 10.49 \\
\hline 211 & 19.34164 & -155.276 & $1 / 17 / 2018$ & 1.49 & Andisols & 0 & 4.78 & 47.38 & 2.41 & 11.95 & 12.96 & 0.16 & 9.45 \\
\hline 212 & 19.33681 & -155.276 & $1 / 17 / 2018$ & 1.77 & Andisols & 0 & 4.72 & 46.05 & 2.38 & 11.57 & 13.30 & 0.17 & 10.40 \\
\hline 213 & 19.34472 & -155.291 & $1 / 17 / 2018$ & 0.51 & Fresh Basalt & 0 & 4.53 & 48.02 & 2.14 & 10.52 & 13.28 & 0.17 & 13.99 \\
\hline 214 & 19.34154 & -155.294 & $1 / 17 / 2018$ & 0.25 & Fresh Basalt & 0 & 4.00 & 49.70 & 2.32 & 10.73 & 13.32 & 0.17 & 11.75 \\
\hline 215 & 19.34954 & -155.307 & $1 / 17 / 2018$ & 0.20 & Fresh Basalt & 0 & 3.85 & 48.20 & 2.16 & 10.08 & 14.01 & 0.17 & 14.75 \\
\hline 216 & 19.34673 & -155.311 & $1 / 17 / 2018$ & 0.23 & Fresh Basalt & 1 & 3.74 & 48.88 & 2.35 & 10.94 & 13.84 & 0.17 & 12.20 \\
\hline 217 & 19.28947 & -155.108 & $1 / 17 / 2018$ & 2.15 & Fresh Basalt & 1 & 4.74 & 46.70 & 2.19 & 11.41 & 12.41 & 0.16 & 10.55 \\
\hline 218 & 19.42654 & -155.295 & $?$ & 13.36 & Andisols & 1 & 7.78 & 30.04 & 1.30 & 7.60 & 7.70 & 0.12 & 5.73 \\
\hline 219 & 19.40616 & -155.253 & $1 / 17 / 2018$ & 32.47 & Andisols & 1 & 4.35 & NA & NA & NA & NA & NA & NA \\
\hline 220 & 19.40839 & -155.255 & $1 / 17 / 2018$ & 1.50 & Fresh Basalt & 1 & 7.15 & 45.47 & 2.02 & 9.73 & 12.85 & 0.17 & 16.23 \\
\hline 221 & 19.31682 & -155.162 & $1 / 17 / 2018$ & 23.63 & Fresh Basalt & 1 & 5.01 & 22.00 & 1.07 & 5.54 & 5.70 & 0.08 & 3.61 \\
\hline 222 & 19.41373 & -155.24 & $1 / 17 / 2018$ & 29.61 & Andisols & 1 & 4.27 & NA & NA & NA & NA & NA & NA \\
\hline 223 & 19.31436 & -155.151 & $1 / 17 / 2018$ & 5.76 & Fresh Basalt & 1 & 5.63 & 40.78 & 1.97 & 10.36 & 11.00 & 0.15 & 8.65 \\
\hline 224 & 19.29248 & -155.144 & $1 / 17 / 2018$ & 31.91 & Fresh Basalt & 1 & 5.59 & 17.53 & 0.41 & 2.28 & 2.19 & 0.04 & 1.44 \\
\hline 225 & 19.41375 & -155.24 & $1 / 18 / 2018$ & 0.89 & Andisols & 0 & 4.65 & 45.06 & 1.49 & 10.13 & 15.68 & 0.17 & 15.30 \\
\hline 226 & 19.42032 & -155.289 & $1 / 17 / 2018$ & 27.99 & Andisols & 1 & 4.96 & 17.72 & 0.78 & 4.12 & 4.51 & 0.06 & 3.52 \\
\hline 227 & 19.42942 & -155.257 & $1 / 17 / 2018$ & 5.28 & Andisols & 1 & 4.68 & 41.27 & 1.95 & 10.39 & 11.53 & 0.14 & 9.37 \\
\hline 228 & 19.43159 & -155.268 & $1 / 17 / 2018$ & 2.80 & Fresh Basalt & 1 & 4.90 & 45.63 & 2.25 & 11.56 & 12.40 & 0.16 & 9.58 \\
\hline 229 & 19.39209 & -155.306 & $1 / 19 / 2018$ & 0.40 & Fresh Basalt & 0 & 4.40 & 48.20 & 2.32 & 10.64 & 14.04 & 0.17 & 13.17 \\
\hline 230 & 19.37234 & -155.304 & $1 / 19 / 2018$ & 0.22 & Fresh Basalt & 0 & 3.82 & 49.73 & 2.31 & 11.45 & 13.15 & 0.17 & 10.87 \\
\hline 231 & 19.3904 & -155.294 & $1 / 19 / 2018$ & 0.23 & Entisols & 0 & 4.12 & 50.25 & 2.33 & 11.74 & 13.08 & 0.17 & 9.64 \\
\hline 232 & 19.40098 & -155.283 & $1 / 19 / 2018$ & 0.30 & Fresh Basalt & 0 & 3.63 & 56.27 & 2.64 & 8.11 & 12.28 & 0.15 & 7.95 \\
\hline 233 & 19.47336 & -155.262 & $1 / 18 / 2018$ & 10.54 & Andisols & 1 & 6.08 & 34.36 & 1.82 & 10.40 & 10.60 & 0.15 & 6.12 \\
\hline 234 & 19.42574 & -155.239 & $1 / 17 / 2018$ & 9.98 & Andisols & 1 & 4.57 & 33.92 & 1.60 & 9.67 & 9.14 & 0.14 & 5.06 \\
\hline 235 & 19.36485 & -155.215 & $1 / 18 / 2018$ & 30.54 & Andisols & 0 & 4.25 & NA & NA & NA & NA & NA & NA \\
\hline 236 & 19.37109 & -155.205 & $1 / 18 / 2018$ & 43.05 & Andisols & 1 & 4.27 & NA & NA & NA & NA & NA & NA \\
\hline 237 & 19.4006 & -155.267 & $1 / 19 / 2018$ & 0.28 & Fresh Basalt & 0 & 4.83 & 47.27 & 2.13 & 10.46 & 13.13 & 0.17 & 15.62 \\
\hline 238 & 19.44765 & -155.203 & $1 / 19 / 2018$ & 2.83 & Andisols & 1 & 5.99 & 30.57 & 1.48 & 8.53 & 33.66 & 0.20 & 5.92 \\
\hline 239 & 19.43759 & -155.303 & $1 / 18 / 2018$ & 12.51 & Andisols & 1 & 5.38 & 32.87 & 1.57 & 9.02 & 9.35 & 0.13 & 6.63 \\
\hline 240 & 19.40379 & -155.341 & $?$ & 0.66 & Andisols & 0 & 5.39 & 50.70 & 2.03 & 13.53 & 12.10 & 0.17 & 7.29 \\
\hline 241 & 19.40401 & -155.342 & $?$ & 3.32 & Andisols & 1 & 4.92 & 44.76 & 2.18 & 11.98 & 12.39 & 0.17 & 9.10 \\
\hline 242 & 19.38285 & -155.319 & $1 / 19 / 2018$ & 0.37 & Fresh Basalt & 0 & 4.71 & 47.84 & 2.63 & 11.05 & 14.49 & 0.18 & 11.13 \\
\hline 243 & 19.35313 & -155.346 & $1 / 19 / 2018$ & 0.32 & Fresh Basalt & 0 & 4.45 & 49.22 & 2.29 & 11.28 & 13.45 & 0.17 & 11.62 \\
\hline 244 & 19.37917 & -155.209 & $1 / 19 / 2018$ & 0.26 & Andisols & 0 & 5.03 & 49.45 & 2.44 & 11.93 & 13.32 & 0.17 & 10.34 \\
\hline
\end{tabular}




\begin{tabular}{|c|c|c|c|c|c|c|c|c|c|c|c|c|c|}
\hline Sample & $\begin{array}{c}\mathrm{CaO} \\
\text { weight \% }\end{array}$ & $\begin{array}{c}\mathrm{Na}_{2} \mathrm{O} \\
\text { weight \% }\end{array}$ & $\begin{array}{c}\mathrm{K}_{2} \mathrm{O} \\
\text { weight \% }\end{array}$ & $\begin{array}{c}\mathrm{P}_{2} \mathrm{O}_{5} \\
\text { weight \% }\end{array}$ & $\begin{array}{c}\mathrm{Ba} \\
\mathrm{ppm}\end{array}$ & $\begin{array}{c}\mathrm{Ce} \\
\mathrm{ppm}\end{array}$ & $\begin{array}{c}\mathrm{Cr} \\
\mathrm{ppm}\end{array}$ & $\begin{array}{c}\mathrm{Cu} \\
\mathrm{ppm}\end{array}$ & $\begin{array}{c}\mathrm{Ga} \\
\mathrm{ppm}\end{array}$ & $\begin{array}{c}\mathrm{La} \\
\mathrm{ppm}\end{array}$ & $\begin{array}{l}\mathrm{Nb} \\
\mathrm{ppm}\end{array}$ & $\begin{array}{l}\mathrm{Nd} \\
\mathrm{ppm}\end{array}$ & $\begin{array}{c}\mathrm{Ni} \\
\mathrm{ppm}\end{array}$ \\
\hline 21 & 9.77 & 1.87 & 0.37 & 0.24 & 0.0099 & 0.0023 & 0.0516 & 0.0089 & 0.0016 & 0.0008 & 0.0011 & 0.0015 & 0.0251 \\
\hline 22 & 8.74 & 1.59 & 0.35 & 0.23 & 0.0054 & 0.0015 & 0.0509 & 0.0083 & 0.0013 & 0.0005 & 0.0008 & 0.0013 & 0.0303 \\
\hline 23 & 9.08 & 1.82 & 0.55 & 0.69 & 0.0088 & 0.0027 & 0.0583 & 0.0104 & 0.0017 & 0.0008 & 0.0011 & 0.0017 & 0.0262 \\
\hline 24 & 8.94 & 1.81 & 0.40 & 0.26 & 0.0073 & 0.0026 & 0.0481 & 0.0152 & 0.0016 & 0.0010 & 0.0012 & 0.0018 & 0.0288 \\
\hline 25 & 8.72 & 2.25 & 0.65 & 0.35 & 0.0131 & 0.0045 & 0.0379 & 0.0096 & 0.0021 & 0.0013 & 0.0019 & 0.0027 & 0.0186 \\
\hline 26 & 8.21 & 1.48 & 0.31 & 0.26 & 0.0060 & 0.0024 & 0.0601 & 0.0113 & 0.0020 & 0.0008 & 0.0012 & 0.0023 & 0.0259 \\
\hline 209 & 7.97 & 1.37 & 0.31 & 0.27 & 0.0048 & 0.0016 & 0.0459 & 0.0076 & 0.0012 & 0.0007 & 0.0008 & 0.0011 & 0.0245 \\
\hline 211 & 9.54 & 1.82 & 0.40 & 0.23 & 0.0062 & 0.0021 & 0.0532 & 0.0096 & 0.0017 & 0.0008 & 0.0012 & 0.0013 & 0.0227 \\
\hline 212 & 9.07 & 1.63 & 0.36 & 0.22 & 0.0062 & 0.0019 & 0.0715 & 0.0104 & 0.0019 & 0.0007 & 0.0013 & 0.0017 & 0.0343 \\
\hline 213 & 8.87 & 1.62 & 0.38 & 0.22 & 0.0065 & 0.0021 & 0.0912 & 0.0086 & 0.0016 & 0.0007 & 0.0012 & 0.0020 & 0.0575 \\
\hline 214 & 9.01 & 1.69 & 0.39 & 0.20 & 0.0068 & 0.0019 & 0.0734 & 0.0094 & 0.0018 & 0.0010 & 0.0013 & 0.0016 & 0.0435 \\
\hline 215 & 8.51 & 1.57 & 0.36 & 0.17 & 0.0062 & 0.0017 & 0.0820 & 0.0084 & 0.0016 & 0.0007 & 0.0012 & 0.0017 & 0.0582 \\
\hline 216 & 9.34 & 1.75 & 0.39 & 0.20 & 0.0067 & 0.0022 & 0.0805 & 0.0097 & 0.0018 & 0.0008 & 0.0013 & 0.0018 & 0.0434 \\
\hline 217 & 8.85 & 1.73 & 0.36 & 0.25 & 0.0065 & 0.0019 & 0.0575 & 0.0087 & 0.0017 & 0.0009 & 0.0012 & 0.0017 & 0.0372 \\
\hline 218 & 7.59 & 1.18 & 0.30 & 0.28 & 0.0079 & 0.0009 & 0.0197 & 0.0062 & 0.0008 & 0.0004 & 0.0004 & 0.0008 & 0.0119 \\
\hline 219 & NA & NA & NA & NA & NA & NA & NA & NA & NA & NA & NA & NA & NA \\
\hline 220 & 8.60 & 1.55 & 0.42 & 0.22 & 0.0076 & 0.0024 & 0.0942 & 0.0080 & 0.0014 & 0.0007 & 0.0013 & 0.0016 & 0.0578 \\
\hline 221 & 5.05 & 0.81 & 0.22 & 0.21 & NA & NA & NA & NA & NA & NA & NA & NA & NA \\
\hline 222 & NA & NA & NA & NA & NA & NA & NA & NA & NA & NA & NA & NA & NA \\
\hline 223 & 7.86 & 1.49 & 0.32 & 0.24 & 0.0058 & 0.0019 & 0.0467 & 0.0076 & 0.0015 & 0.0006 & 0.0010 & 0.0016 & 0.0276 \\
\hline 224 & 2.91 & 0.26 & 0.11 & 0.27 & NA & NA & NA & NA & NA & NA & NA & NA & NA \\
\hline 225 & 7.69 & 1.46 & 0.27 & 0.19 & 0.0044 & 0.0012 & 0.1035 & 0.0095 & 0.0017 & 0.0003 & 0.0008 & 0.0023 & 0.0714 \\
\hline 226 & 3.89 & 0.60 & 0.16 & 0.16 & NA & NA & NA & NA & NA & NA & NA & NA & NA \\
\hline 227 & 7.98 & 1.48 & 0.31 & 0.35 & 0.0058 & 0.0017 & 0.0553 & 0.0087 & 0.0014 & 0.0005 & 0.0009 & 0.0016 & 0.0279 \\
\hline 228 & 9.07 & 1.68 & 0.35 & 0.21 & 0.0063 & 0.0017 & 0.0608 & 0.0101 & 0.0018 & 0.0007 & 0.0012 & 0.0016 & 0.0291 \\
\hline 229 & 8.81 & 1.61 & 0.35 & 0.21 & 0.0061 & 0.0017 & 0.0866 & 0.0103 & 0.0018 & 0.0005 & 0.0013 & 0.0018 & 0.0527 \\
\hline 230 & 9.56 & 1.82 & 0.38 & 0.20 & 0.0066 & 0.0020 & 0.0654 & 0.0085 & 0.0019 & 0.0008 & 0.0013 & 0.0017 & 0.0369 \\
\hline 231 & 9.71 & 1.88 & 0.41 & 0.21 & 0.0074 & 0.0017 & 0.0599 & 0.0095 & 0.0020 & 0.0008 & 0.0013 & 0.0013 & 0.0270 \\
\hline 232 & 7.79 & 1.35 & 0.47 & 0.15 & 0.0082 & 0.0018 & 0.0649 & 0.0083 & 0.0016 & 0.0004 & 0.0015 & 0.0011 & 0.0213 \\
\hline 233 & 6.21 & 1.11 & 0.27 & 0.41 & 0.0035 & 0.0015 & 0.0400 & 0.0073 & 0.0011 & 0.0006 & 0.0007 & 0.0014 & 0.0140 \\
\hline 234 & 6.37 & 1.23 & 0.27 & 0.45 & 0.0059 & 0.0015 & 0.0279 & 0.0180 & 0.0011 & 0.0006 & 0.0006 & 0.0012 & 0.0111 \\
\hline 235 & NA & NA & NA & NA & NA & NA & NA & NA & NA & NA & NA & NA & NA \\
\hline 236 & NA & NA & NA & NA & NA & NA & NA & NA & NA & NA & NA & NA & NA \\
\hline 237 & 9.26 & 1.65 & 0.44 & 0.21 & 0.0086 & 0.0023 & 0.1200 & 0.0094 & 0.0017 & 0.0012 & 0.0016 & 0.0019 & 0.0702 \\
\hline 238 & 6.20 & 1.13 & 0.24 & 0.24 & 0.0174 & 0.0017 & 0.0498 & 0.0488 & 0.0017 & 0.0008 & 0.0010 & 0.0050 & 0.0271 \\
\hline 239 & 6.00 & 1.02 & 0.24 & 0.33 & 0.0043 & 0.0013 & 0.0350 & 0.0072 & 0.0010 & 0.0005 & 0.0006 & 0.0013 & 0.0183 \\
\hline 240 & 10.33 & 2.25 & 0.45 & 0.24 & 0.0068 & 0.0023 & 0.0319 & 0.0137 & 0.0019 & 0.0007 & 0.0010 & 0.0015 & 0.0132 \\
\hline 241 & 8.79 & 1.66 & 0.34 & 0.30 & 0.0063 & 0.0026 & 0.0602 & 0.0099 & 0.0017 & 0.0007 & 0.0011 & 0.0017 & 0.0259 \\
\hline 242 & 9.22 & 1.68 & 0.39 & 0.22 & 0.0067 & 0.0022 & 0.0821 & 0.0113 & 0.0020 & 0.0010 & 0.0014 & 0.0016 & 0.0378 \\
\hline 243 & 9.32 & 1.75 & 0.39 & 0.21 & 0.0068 & 0.0022 & 0.0741 & 0.0100 & 0.0018 & 0.0006 & 0.0013 & 0.0017 & 0.0420 \\
\hline 244 & 9.51 & 1.88 & 0.40 & 0.24 & 0.0072 & 0.0023 & 0.0568 & 0.0096 & 0.0020 & 0.0008 & 0.0014 & 0.0018 & 0.0349 \\
\hline
\end{tabular}




\begin{tabular}{|c|c|c|c|c|c|c|c|c|c|c|c|}
\hline Sample & $\begin{array}{c}\mathrm{Pb} \\
\mathrm{ppm}\end{array}$ & $\begin{array}{c}\mathrm{Rb} \\
\mathrm{ppm}\end{array}$ & $\begin{array}{c}\mathrm{Sc} \\
\mathrm{ppm}\end{array}$ & $\begin{array}{c}\mathrm{Sm} \\
\mathrm{ppm}\end{array}$ & $\begin{array}{c}\mathrm{Sr} \\
\mathrm{ppm}\end{array}$ & $\begin{array}{c}\text { Th } \\
\mathrm{ppm}\end{array}$ & $\begin{array}{c}\mathrm{U} \\
\mathrm{ppm}\end{array}$ & $\begin{array}{c}\mathrm{V} \\
\mathrm{ppm}\end{array}$ & $\begin{array}{c}\mathrm{Y} \\
\mathrm{ppm}\end{array}$ & $\begin{array}{c}\mathrm{Zn} \\
\mathrm{ppm}\end{array}$ & $\begin{array}{c}\mathrm{Zr} \\
\mathrm{ppm}\end{array}$ \\
\hline 21 & 0.0084 & 0.0007 & 0.0026 & 0.0004 & 0.0242 & 0.00001 & 0.00000 & 0.0248 & 0.0021 & 0.0357 & 0.0116 \\
\hline 22 & 0.0001 & 0.0006 & 0.0021 & 0.0004 & 0.0180 & 0.00003 & 0.00000 & 0.0195 & 0.0016 & 0.0084 & 0.0092 \\
\hline 23 & 0.0258 & 0.0009 & 0.0024 & 0.0004 & 0.0235 & 0.00035 & 0.00000 & 0.0235 & 0.0021 & 0.0563 & 0.0114 \\
\hline 24 & 0.0013 & 0.0008 & 0.0027 & 0.0005 & 0.0255 & 0.00000 & 0.00000 & 0.0265 & 0.0022 & 0.0448 & 0.0127 \\
\hline 25 & 0.0006 & 0.0014 & 0.0028 & 0.0006 & 0.0313 & 0.00016 & 0.00006 & 0.0306 & 0.0036 & 0.0140 & 0.0218 \\
\hline 26 & 0.0001 & 0.0008 & 0.0032 & 0.0006 & 0.0225 & 0.00000 & 0.00000 & 0.0330 & 0.0026 & 0.0115 & 0.0144 \\
\hline 209 & 0.0000 & 0.0006 & 0.0019 & 0.0004 & 0.0168 & 0.00000 & 0.00000 & 0.0183 & 0.0015 & 0.0086 & 0.0084 \\
\hline 211 & 0.0003 & 0.0008 & 0.0028 & 0.0004 & 0.0246 & 0.00000 & 0.00000 & 0.0269 & 0.0021 & 0.0093 & 0.0126 \\
\hline 212 & 0.0001 & 0.0008 & 0.0032 & 0.0005 & 0.0252 & 0.00000 & 0.00000 & 0.0317 & 0.0023 & 0.0105 & 0.0141 \\
\hline 213 & 0.0001 & 0.0008 & 0.0028 & 0.0004 & 0.0248 & 0.00000 & 0.00000 & 0.0274 & 0.0021 & 0.0103 & 0.0125 \\
\hline 214 & 0.0002 & 0.0008 & 0.0030 & 0.0005 & 0.0265 & 0.00005 & 0.00003 & 0.0299 & 0.0021 & 0.0106 & 0.0135 \\
\hline 215 & 0.0001 & 0.0007 & 0.0028 & 0.0005 & 0.0243 & 0.00003 & 0.00002 & 0.0272 & 0.0020 & 0.0106 & 0.0122 \\
\hline 216 & 0.0000 & 0.0008 & 0.0031 & 0.0005 & 0.0272 & 0.00000 & 0.00000 & 0.0317 & 0.0023 & 0.0111 & 0.0139 \\
\hline 217 & 0.0001 & 0.0010 & 0.0028 & 0.0005 & 0.0255 & 0.00000 & 0.00002 & 0.0270 & 0.0022 & 0.0112 & 0.0131 \\
\hline 218 & 0.0007 & 0.0004 & 0.0012 & 0.0002 & 0.0153 & 0.00001 & 0.00000 & 0.0123 & 0.0011 & 0.0140 & 0.0055 \\
\hline 219 & NA & NA & NA & NA & NA & NA & NA & NA & NA & NA & NA \\
\hline 220 & 0.0002 & 0.0008 & 0.0025 & 0.0004 & 0.0254 & 0.00009 & 0.00003 & 0.0242 & 0.0018 & 0.0091 & 0.0113 \\
\hline 221 & NA & NA & NA & NA & NA & NA & NA & NA & NA & NA & NA \\
\hline 222 & NA & NA & NA & NA & NA & NA & NA & NA & NA & NA & NA \\
\hline 223 & 0.0002 & 0.0008 & 0.0023 & 0.0004 & 0.0208 & 0.00003 & 0.00002 & 0.0225 & 0.0019 & 0.0090 & 0.0106 \\
\hline 224 & NA & NA & NA & NA & NA & NA & NA & NA & NA & NA & NA \\
\hline 225 & 0.0003 & 0.0006 & 0.0024 & 0.0006 & 0.0223 & 0.00000 & 0.00000 & 0.0218 & 0.0018 & 0.0192 & 0.0096 \\
\hline 226 & NA & NA & NA & NA & NA & NA & NA & NA & NA & NA & NA \\
\hline 227 & 0.0029 & 0.0006 & 0.0023 & 0.0004 & 0.0197 & 0.00000 & 0.00000 & 0.0222 & 0.0018 & 0.0133 & 0.0102 \\
\hline 228 & 0.0018 & 0.0008 & 0.0029 & 0.0004 & 0.0248 & 0.00005 & 0.00000 & 0.0290 & 0.0020 & 0.0100 & 0.0133 \\
\hline 229 & 0.0001 & 0.0008 & 0.0031 & 0.0005 & 0.0246 & 0.00000 & 0.00000 & 0.0307 & 0.0020 & 0.0110 & 0.0137 \\
\hline 230 & 0.0000 & 0.0008 & 0.0031 & 0.0004 & 0.0282 & 0.00000 & 0.00000 & 0.0302 & 0.0023 & 0.0106 & 0.0140 \\
\hline 231 & 0.0003 & 0.0008 & 0.0031 & 0.0005 & 0.0295 & 0.00000 & 0.00000 & 0.0310 & 0.0023 & 0.0107 & 0.0140 \\
\hline 232 & 0.0006 & 0.0010 & 0.0030 & 0.0005 & 0.0238 & 0.00008 & 0.00000 & 0.0321 & 0.0020 & 0.0098 & 0.0168 \\
\hline 233 & 0.0003 & 0.0006 & 0.0018 & 0.0004 & 0.0127 & 0.00004 & 0.00005 & 0.0177 & 0.0014 & 0.0139 & 0.0080 \\
\hline 234 & 0.0172 & 0.0006 & 0.0015 & 0.0004 & 0.0137 & 0.00030 & 0.00001 & 0.0150 & 0.0014 & 0.0195 & 0.0072 \\
\hline 235 & NA & NA & NA & NA & NA & NA & NA & NA & NA & NA & NA \\
\hline 236 & NA & NA & NA & NA & NA & NA & NA & NA & NA & NA & NA \\
\hline 237 & 0.0003 & 0.0010 & 0.0030 & 0.0005 & 0.0295 & 0.00008 & 0.00000 & 0.0284 & 0.0021 & 0.0106 & 0.0133 \\
\hline 238 & 0.0624 & 0.0008 & 0.0018 & 0.0012 & 0.0160 & 0.00082 & 0.00000 & 0.0199 & 0.0017 & 0.2197 & 0.0093 \\
\hline 239 & 0.0018 & 0.0005 & 0.0015 & 0.0004 & 0.0128 & 0.00009 & 0.00004 & 0.0143 & 0.0013 & 0.0100 & 0.0070 \\
\hline 240 & 0.0002 & 0.0008 & 0.0032 & 0.0004 & 0.0314 & 0.00000 & 0.00000 & 0.0285 & 0.0025 & 0.0202 & 0.0125 \\
\hline 241 & 0.0001 & 0.0008 & 0.0029 & 0.0005 & 0.0239 & 0.00007 & 0.00006 & 0.0273 & 0.0023 & 0.0109 & 0.0125 \\
\hline 242 & 0.0002 & 0.0009 & 0.0034 & 0.0005 & 0.0262 & 0.00010 & 0.00009 & 0.0350 & 0.0022 & 0.0114 & 0.0150 \\
\hline 243 & 0.0003 & 0.0008 & 0.0032 & 0.0005 & 0.0272 & 0.00009 & 0.00004 & 0.0306 & 0.0022 & 0.0107 & 0.0137 \\
\hline 244 & 0.0046 & 0.0008 & 0.0032 & 0.0005 & 0.0287 & 0.00005 & 0.00000 & 0.0318 & 0.0023 & 0.0104 & 0.0151 \\
\hline
\end{tabular}




\begin{tabular}{|c|c|c|c|c|c|c|c|c|}
\hline Sample & $\begin{array}{c}1: 1 \text { clays } \\
\%\end{array}$ & $\begin{array}{c}2: 1 \text { clays } \\
\%\end{array}$ & $\begin{array}{c}\text { Carbonate } \\
\%\end{array}$ & $\begin{array}{c}\text { Feldspar } \\
\%\end{array}$ & $\begin{array}{c}\text { Goethite } \\
\%\end{array}$ & $\begin{array}{c}\text { Ilmenite } \\
\%\end{array}$ & $\begin{array}{c}\text { Iron Oxides } \\
\%\end{array}$ & $\begin{array}{c}\text { Mafic Silicates } \\
\%\end{array}$ \\
\hline 21 & NA & NA & NA & 29.3 & $\mathrm{NA}$ & 0.1 & 10.8 & 59.9 \\
\hline 22 & NA & NA & NA & 44.0 & NA & 7.4 & 7.2 & 41.3 \\
\hline 23 & NA & NA & NA & 37.5 & NA & NA & 6.5 & 56.1 \\
\hline 24 & NA & NA & 5.3 & 60.6 & NA & 0.8 & 2.8 & 30.5 \\
\hline 25 & NA & NA & 2.1 & 92.5 & NA & 1.0 & 2.1 & 2.4 \\
\hline 26 & NA & NA & NA & 30.6 & NA & 5.6 & 0.0 & 63.8 \\
\hline 209 & NA & NA & 12.7 & 28.2 & NA & 3.5 & 4.5 & 51.1 \\
\hline 211 & NA & NA & NA & 49.9 & NA & 1.7 & 11.6 & 36.7 \\
\hline 212 & NA & NA & 0.6 & 40.7 & NA & 3.1 & 7.7 & 47.9 \\
\hline 213 & NA & NA & NA & 44.5 & NA & 0.9 & 5.8 & 48.7 \\
\hline 214 & NA & NA & NA & 32.8 & NA & NA & 9.4 & 57.8 \\
\hline 215 & NA & NA & 3.3 & 34.7 & NA & 1.2 & 6.3 & 54.6 \\
\hline 216 & NA & NA & 9.4 & 34.9 & 2.8 & 3.1 & 11.4 & 38.4 \\
\hline 217 & NA & NA & NA & 28.0 & NA & 7.5 & NA & 64.5 \\
\hline 218 & NA & NA & NA & 50.2 & NA & 5.1 & 2.3 & 42.4 \\
\hline 219 & 5.9 & 4.9 & NA & 89.2 & NA & NA & NA & NA \\
\hline 220 & NA & NA & NA & 12.0 & NA & NA & 3.1 & 85.0 \\
\hline 221 & NA & NA & NA & 37.5 & NA & 2.5 & 18.4 & 41.6 \\
\hline 222 & NA & NA & NA & 63.8 & NA & 1.3 & 7.2 & 27.7 \\
\hline 223 & NA & NA & 1.5 & 50.2 & NA & 0.1 & 5.9 & 42.3 \\
\hline 224 & NA & NA & NA & 59.3 & NA & NA & 6.1 & 34.6 \\
\hline 225 & NA & NA & NA & 37.8 & NA & 1.6 & 2.6 & 58.0 \\
\hline 226 & NA & NA & NA & 39.7 & NA & 3.8 & 8.1 & 48.4 \\
\hline 227 & NA & NA & NA & 33.9 & NA & 8.0 & 9.3 & 48.8 \\
\hline 228 & NA & NA & NA & 35.1 & NA & 0.4 & 6.3 & 58.2 \\
\hline 229 & NA & NA & NA & 42.0 & NA & 0.3 & 6.3 & 51.4 \\
\hline 230 & NA & NA & NA & 32.3 & NA & 1.6 & 13.3 & 52.8 \\
\hline 231 & NA & NA & NA & 46.4 & NA & NA & 7.5 & 46.2 \\
\hline 232 & NA & NA & NA & 62.2 & NA & 0.1 & NA & 37.8 \\
\hline 233 & NA & NA & NA & 44.2 & NA & NA & 4.3 & 51.5 \\
\hline 234 & NA & NA & NA & 43.0 & NA & 6.9 & 2.3 & 47.7 \\
\hline 235 & NA & NA & NA & 96.7 & 0.4 & NA & NA & 2.9 \\
\hline 236 & NA & NA & NA & 88.2 & 11.8 & NA & NA & NA \\
\hline 237 & NA & NA & NA & 29.6 & NA & NA & 2.7 & 67.8 \\
\hline 238 & NA & NA & NA & 29.9 & 20.7 & 6.1 & 3.9 & 39.4 \\
\hline 239 & NA & NA & 2.7 & 55.0 & NA & 0.5 & 4.9 & 36.9 \\
\hline 240 & NA & NA & NA & 50.9 & NA & NA & 4.6 & 44.5 \\
\hline 241 & NA & NA & 5.9 & 21.1 & NA & 13.8 & 0.2 & 59.0 \\
\hline 242 & NA & NA & 3.9 & 32.3 & NA & 2.2 & 6.0 & 55.7 \\
\hline 243 & 1.0 & NA & 18.3 & 41.6 & NA & 0.7 & 2.0 & 36.5 \\
\hline 244 & NA & NA & 10.0 & 44.1 & NA & 0.6 & 0.9 & 44.4 \\
\hline
\end{tabular}


Appendix C. Stream to Aquifer Modeling from Nelson et al. (In Press)

NTM have typical lengths of 1.5 to $2.5 \mu \mathrm{m}$, and a width of $<0.5 \mu \mathrm{m}$. Being rod shaped, cells will be aligned with flow directions, so the most critical dimension to prevent auto-filtration in the aquifer will be the width of the cell \pm the width of any attached mineral grain. This establishes a minimum fracture aperture network of $\sim 1 \mathrm{~mm}$ between the stream bed and the aquifer for NTM transport.

Analytical solutions for fracture flow are relevant for constraining fracture apertures and infiltration depths. For a $1 \mathrm{~m}$ wide $(W)$ fracture, Bear's (1972; Konzuk and Kueper, 2004) law (1A) for fracture flow can be reduced to (1B):

$$
\begin{gathered}
Q=-\frac{W \rho e^{3}}{12 \mu} \frac{\Delta h}{\Delta L}=-v A=-v W e(1 A) \\
v=\frac{\rho e^{2}}{12 \mu} \frac{\Delta h}{\Delta L}(1 \mathrm{~B})
\end{gathered}
$$

where:

$$
\begin{gathered}
Q=\text { flux } \frac{\mathrm{m}^{3}}{\mathrm{~s}} \\
v=\text { mean velocity } \frac{\mathrm{m}}{\mathrm{s}} \\
W=\text { fracture width } \mathrm{m} \\
\rho=\text { density } \frac{\mathrm{kg}}{\mathrm{m}^{3}}=1000 \frac{\mathrm{kg}}{\mathrm{m}^{3}} \\
e=\text { fracture aperture } \mathrm{m} \\
\Delta h=\text { hydraulic head } \mathrm{m} \\
\Delta L=\text { fracture length } \mathrm{m} \\
v=\text { mean velocity } \frac{\mathrm{m}}{\mathrm{s}} \\
\text { dynic viscosity Pa } \mathrm{s}=8.9 \times 10^{-4} \mathrm{~Pa} \cdot \mathrm{s} \\
\text { fracture cross }- \text { sectional area } \mathrm{m}^{2}
\end{gathered}
$$


A graphical representation for hypothetical travel times to the aquifer for various fracture apertures are shown in Figure A, where the hydraulic head $(\Delta h)$ is assumed to be the distance between the stream surface and the aquifer. As the freshwater lens beneath volcanic islands rises only very gradually inland, and stream elevations are low, travel times may be very short for coastal regions like Waimea. Over these short distances, the likelihood of an interconnected fracture network increases. Indeed, the majority of wells on Oahu are concentrated near the shoreline (Gingerich and Oki, 2000) where elevations are low and potential travel times to the aquifer are short. Well-known size-exclusion effects for colloids dictate that the calculated travel-time curves (Fig. A) are minimum values as particles tend to remain in the high-velocity flow regime between fracture walls.

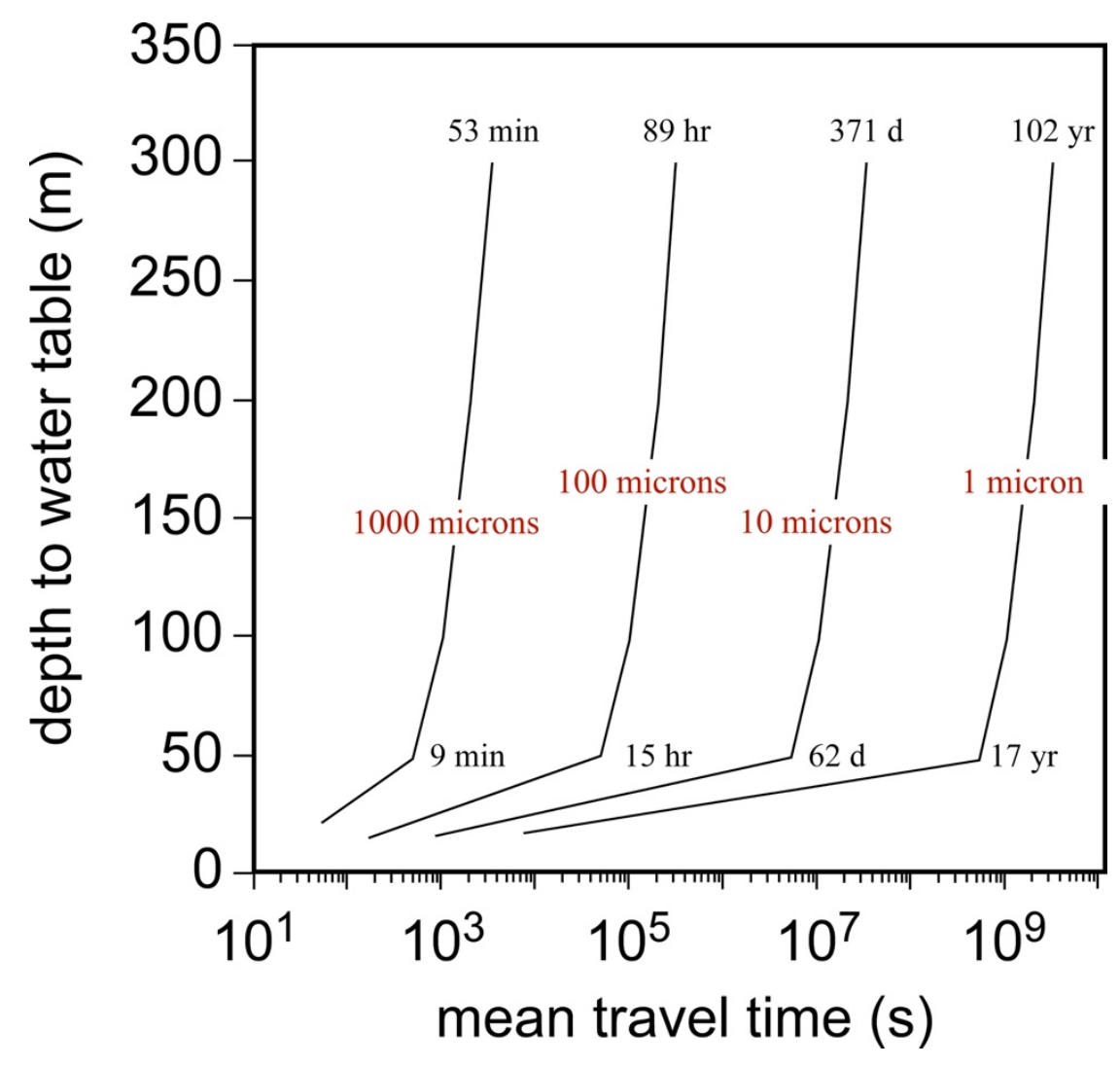

Figure A. Curves representing the solution to Bear's law (1972) for a $1 \mathrm{~m}$-wide fracture for various apertures and variable hydraulic heads (i.e., depth from stream bottom to the aquifer). Transit times for colloidal material, including NTM, can be rapid provided there is an integrated network of fractures between the stream bed and the aquifer. See text for discussion. 